\title{
Article \\ Label-Free Investigations on the G Protein Dependent Signaling Pathways of Histamine Receptors
}

\author{
Ulla Seibel-Ehlert ${ }^{1, *(\mathbb{D})}$, Nicole Plank ${ }^{1}$, Asuka Inoue ${ }^{2}$, Guenther Bernhardt ${ }^{1}\left(\mathbb{D}\right.$ and Andrea Strasser ${ }^{1, *}$ \\ 1 Institute of Pharmacy, Faculty of Chemistry and Pharmacy, University of Regensburg, \\ 93040 Regensburg, Germany; nicole.plank@ur.de (N.P.); guenther.bernhardt@ur.de (G.B.) \\ 2 Department of Pharmacological Sciences, Tohoku University, Sendai 980-8578, Japan; iaska@tohoku.ac.jp \\ * Correspondence: ulla.seibel@ur.de (U.S.-E.); andrea.strasser@ur.de (A.S.); Tel.: +49-941-943-2960 (U.S.-E.); \\ +49-941-943-4821 (A.S.)
}

check for updates

Citation: Seibel-Ehlert, U.; Plank, N.; Inoue, A.; Bernhardt, G.; Strasser, A. Label-Free Investigations on the $G$ Protein Dependent Signaling Pathways of Histamine Receptors. Int. J. Mol. Sci. 2021, 22, 9739. https:// doi.org/10.3390/ijms22189739

Academic Editor: Paul Chazot

Received: 12 August 2021

Accepted: 6 September 2021

Published: 9 September 2021

Publisher's Note: MDPI stays neutral with regard to jurisdictional claims in published maps and institutional affiliations.

Copyright: (c) 2021 by the authors. Licensee MDPI, Basel, Switzerland. This article is an open access article distributed under the terms and conditions of the Creative Commons Attribution (CC BY) license (https:/ / creativecommons.org/licenses/by/ $4.0 /)$.

\begin{abstract}
G protein activation represents an early key event in the complex GPCR signal transduction process and is usually studied by label-dependent methods targeting specific molecular events. However, the constrained environment of such "invasive" techniques could interfere with biological processes. Although histamine receptors (HRs) represent (evolving) drug targets, their signal transduction is not fully understood. To address this issue, we established a non-invasive dynamic mass redistribution (DMR) assay for the human $\mathrm{H}_{1-4}$ Rs expressed in HEK cells, showing excellent signal-to-background ratios above 100 for histamine (HIS) and higher than 24 for inverse agonists with $\mathrm{pEC}_{50}$ values consistent with literature. Taking advantage of the integrative nature of the DMR assay, the involvement of endogenous $\mathrm{G} \alpha_{\mathrm{q} / 11}, \mathrm{G} \alpha_{\mathrm{s}}, \mathrm{G} \alpha_{12 / 13}$ and $\mathrm{G} \beta \gamma$ proteins was explored, pursuing a two-pronged approach, namely that of classical pharmacology ( $G$ protein modulators) and that of molecular biology (G $\alpha$ knock-out HEK cells). We showed that signal transduction of $\mathrm{hH}_{1-4}$ Rs occurred mainly, but not exclusively, via their canonical $\mathrm{G} \alpha$ proteins. For example, in addition to $\mathrm{G} \alpha_{\mathrm{i} / \mathrm{o}}$, the $\mathrm{G} \alpha_{\mathrm{q} / 11}$ protein was proven to contribute to the DMR response of $\mathrm{hH}_{3,4} \mathrm{Rs}$. Moreover, the $\mathrm{G} \alpha_{12 / 13}$ was identified to be involved in the $\mathrm{hH}_{2} \mathrm{R}$ mediated signaling pathway. These results are considered as a basis for future investigations on the (patho)physiological role and the pharmacological potential of $\mathrm{H}_{1-4}$ Rs.
\end{abstract}

Keywords: label-free; dynamic mass redistribution (DMR); G protein coupled receptors (GPCRs); histamine receptors; signaling pathways; $G$ protein inhibitors; $G$ protein knock-out

\section{Introduction}

G protein-coupled receptors (GPCRs), also termed seven-transmembrane-domain receptors (7TMs), are integral membrane proteins that transduce a broad variety of extracellular stimuli, ranging from photons and various small molecules to polypeptides, into the cell. As the largest superfamily of proteins in the human genome, GPCRs are involved in many (patho)physiological processes and represent important drug targets in the treatment of numerous diseases [1,2]. Canonical GPCR signal transduction occurs by binding of an agonist to a receptor, stabilizing an active receptor conformation and allowing the receptor to activate heterotrimeric $G$ proteins, composed of $G \alpha, G \beta$ and $G \gamma$ subunits. Upon GPCR activation, the G proteins dissociate from the receptor and split up into $\mathrm{G} \alpha$ and $\mathrm{G} \beta \gamma$ subunits. Subsequently, both can modulate specific downstream effectors. The $\mathrm{G} \alpha$ proteins are divided into four major classes $\left(\mathrm{G} \alpha_{\mathrm{q} / 11}, \mathrm{G} \alpha_{\mathrm{s}}, \mathrm{G} \alpha_{\mathrm{i} / \mathrm{o}}\right.$ and $\left.\mathrm{G} \alpha_{12 / 13}\right)$, based on sequence similarity and their functional properties [3] and are predominantly associated with certain events in the signaling cascade, such as increase in intracellular $\mathrm{Ca}^{2+}$ and $\mathrm{IP}_{3}\left(\mathrm{G} \alpha_{\mathrm{q} / 11}\right)$, in- or decrease in cAMP level $\left(\mathrm{G} \alpha_{\mathrm{s}}, \mathrm{G} \alpha_{\mathrm{i} / \mathrm{o}}\right.$, respectively) or activation of Rho GTPase $\left(\mathrm{G} \alpha_{12 / 13}\right)$ [3,4]. By contrast, the effects of the $G \beta \gamma$ subunit are more diffuse [5,6]. Historically, GPCR signaling was assumed to occur via activation of a single class of $\mathrm{G} \alpha$ proteins, and therefore the receptors were typically classified accordingly [7]. 
However, scientific progress has revealed a complex network of signaling events including pleiotropic $G$ protein (in-)dependent signaling, constitutive activity, biased agonism, receptor (hetero-)oligomerization and cross talk (reviewed in [8-11]).

To study these processes, a wide range of microtiter assay techniques are available [12-14]. For example, events very proximal to ligand binding, such as ligand induced conformational rearrangement of GPCRs [15], and activation and recruitment of (chimeric) G proteins [16] or $\beta$-arrestins [17] can be monitored. More distal in the signaling cascade, protein-protein interactions can be analyzed [18] as well as changes in the levels of second messengers (e.g., $\mathrm{IP}_{3}, \mathrm{Ca}^{2+}$ and cAMP [19-22]) and the expression of gene reporters [20,23]. Despite numerous advantages, these "invasive" label-dependent methods spotlight only individual events in the complex GPCR signaling cascade and can produce system bias [24]. Moreover, the modification and co-expression of tagged proteins could alter the results. Another issue is that analyses of individual processes in the signaling cascade (yielding different readouts) require different experimental conditions and is often carried out in models of different cellular backgrounds (tissue bias). This makes the comparison between such results difficult.

Label-free approaches represent powerful "non-invasive" alternatives, able to capture the whole cellular response triggered by GPCR activation, independent of the signaling pathways involved and without the need to constrain specific experimental conditions. Therefore, label-free approaches such as optical dynamic mass redistribution (DMR) are gaining increasing attention both in drug discovery and GPCR signal transduction studies [25-28]. In a DMR assay, the measurement is based on the change of the refractive index near the biosensor (Figure 1A). This change is caused by a reorganization of cellular components, accompanied by a morphological rearrangement of the cells. In GPCR research, this is triggered by stimulation of a receptor with a ligand $[29,30]$. As the change in refractive index is measured relative to a baseline, the DMR response can be positively or negatively deflected, depending on both the cell model and the receptor-ligand combination used. Therefore, the DMR signal is a holistic response, reflecting multiple cellular events downstream of receptor activation. Such dynamic response profiles are used to quantify various types of ligand action, including full, partial and inverse agonism, antagonism and allosteric modulation in both native [31,32] and recombinant [33] expression systems. However, due to the complexity of the DMR response, it is difficult to identify which events are reflected by the DMR signal, a phenomenon referred to as a "black box" [34]. Although certain characteristics of the signaling profiles of GPCRs in label-free responses were attributed to the activation of distinct classes of $G \alpha$ proteins $[26,29,35,36]$, there is also evidence to the contrary [37]. Application of $G$ protein modulators such as pertussis toxin (PTX), FR900359 (FR) and cholera toxin (CTX) [37-39] can be used to dissect these $\mathrm{G}$ protein dependent signals [37]. PTX selectively and irreversibly inactivates the $\mathrm{G} \alpha_{\mathrm{i} / \mathrm{o}}$ protein by ADP-ribosylation at the $\mathrm{G} \alpha$-subunit $[20,33,37,40-42]$. CTX locks the $\mathrm{G} \alpha_{\mathrm{s}}$ protein in its GTP bound state by irreversible ADP-ribosylation, leading to a permanent activation of the $\mathrm{G} \alpha_{\mathrm{s}}$ protein, which is in turn uncoupled and no longer available for GPCR recruitment [31-33,37,43]. As ribosylation leads to a maximum activation of the $G \alpha_{\text {s }}$ protein rather than inhibition of the $G \alpha_{s}$ protein, the results should be interpreted with caution. FR (alias UBO-QIC) selectively silences $\mathrm{G} \alpha_{\mathrm{q} / 11}$ signaling by blocking the GDP-release in the $\mathrm{G} \alpha$ subunit $[18,41,44-47]$, which is a mandatory step in $\mathrm{G}$ protein activation. The advantage of such studies is that they can be performed with the same cell model under identical experimental conditions, thereby precluding cell bias. Such investigations have already been performed for a variety of GPCRs [37,38,47-53]. Another approach to investigate the involvement of $G$ proteins in signal transduction is to prevent their expression by knocking out the corresponding genes $[41,54,55]$. An advantage of the knock-out strategy over the administration of $G$ protein modulators is the chance that the $G$ protein can be switched off more precisely. In this study, both approaches were followed to investigate the G protein signaling pathways of histamine $\mathrm{hH}_{1-4}$ receptors by DMR. 

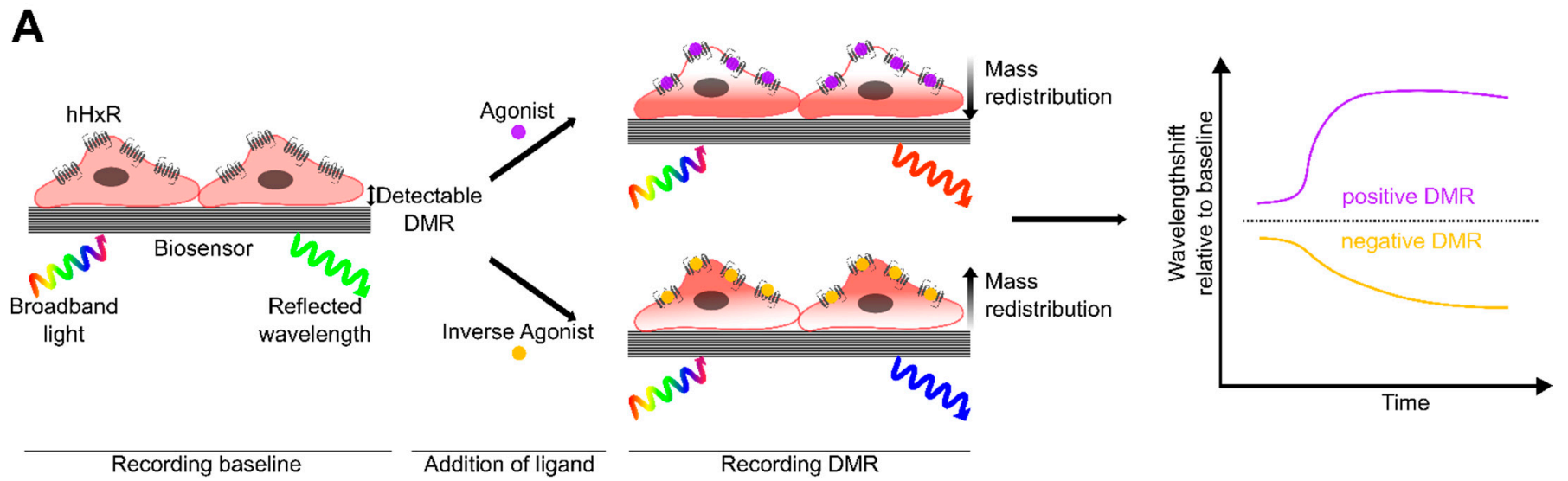

B

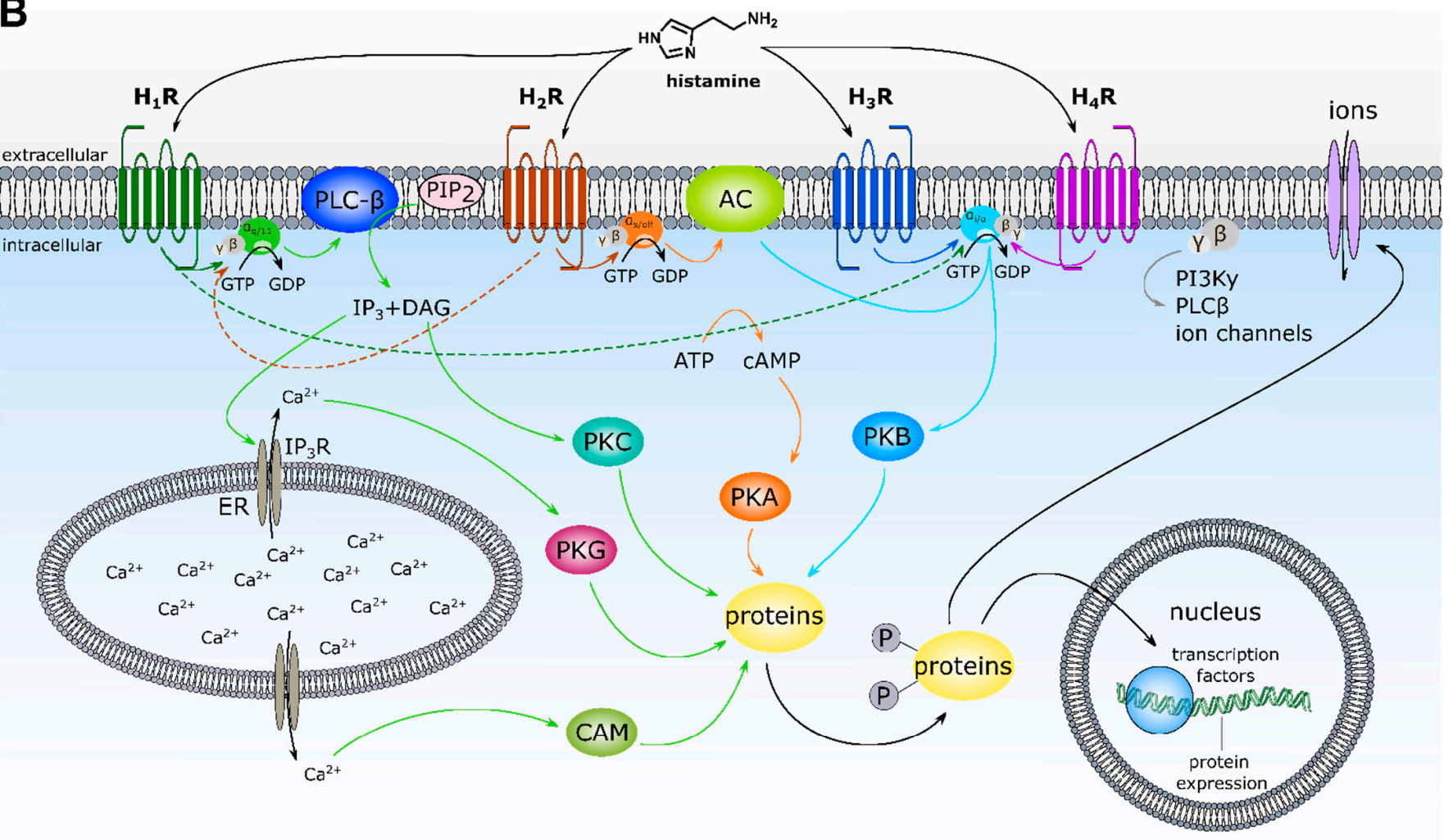

- redistribution of cellular components

- reorganization of cytoskeleton

- changes in cell shape and cell adhesion

- etc.

Figure 1. Schematic illustrations of the principle of the DMR assay and canonical signal transduction of histamine $\mathrm{H}_{1-4} \mathrm{Rs}$. (A) The label-free DMR technology detects changes in the refractive index caused by mass redistribution inside a cell, triggered by receptor stimulation, relative to a baseline. Alteration of the refractive index is measured with a biosensor, integrated in each well of a microplate (adapted from Schröder et al. [38]). (B) Schematic summary of the signal transduction of $\mathrm{H}_{1-4} \mathrm{Rs}$ according to IUPHAR [56] and Panula et al. [57] (adapted from Panula et al. [57]). Canonical G $\alpha$ protein signaling is indicated by solid lines. Involvement of secondary $\mathrm{G} \alpha$ proteins is indicated by dashed lines. AC, adenylyl cyclase; CAM, calcium-modulated protein; CTX, cholera toxin; DAG, diacylglycerol; $\mathrm{IP}_{3}$, inositol-1,4,5-trisphosphate; PI3K $\gamma$, phosphoinositide 3-kinase- $\gamma$; $\mathrm{PIP}_{2}$, phosphatidylinositol-4,5-bisphosphate; PKA, protein kinase A; PKB, protein kinase B; PKC, protein kinase $C$; PLC- $\beta$, phospholipase $C-\beta$; PTX, pertussis toxin. 
Histamine receptors (HRs) represent important drug targets in the treatment of disorders, such as allergy and reflux diseases [58]. They transmit their signals predominantly via three classes of $G$ proteins: $H_{1}$ via $G \alpha_{q / 11}, H_{2}$ via $G \alpha_{s}$ and $H_{3}+H_{4}$ via $G \alpha_{i / o}$ (Figure $1 B$ ). However, for the $\mathrm{H}_{1}$ and $\mathrm{H}_{2}$ receptors, evidence is emerging for promiscuous activation of $G \alpha$ proteins [59-61]. By contrast, less information is available on the involvement of non-canonical $G$ protein subunits in the signal transduction processes of the $\mathrm{H}_{3,4}$ Rs. The first aim of the study was to establish a DMR assay for the entire histamine receptor family to compare the signaling patterns of the $\mathrm{H}_{1-4} \mathrm{Rs}$ in the same experimental setup. For this purpose, the four human receptor subtypes $\left(\mathrm{hH}_{1-4} \mathrm{Rs}\right)$ were stably expressed in HEK cells. HEK cells were chosen as they constitutively express the four relevant $G \alpha$ classes $\left(G \alpha_{\mathrm{s}}, \mathrm{G} \alpha_{\mathrm{q} / 11}, \mathrm{G} \alpha_{12 / 13}\right.$ and $\left.\mathrm{G} \alpha_{\mathrm{i} / \mathrm{o}}\right)$ at comparable levels [62]. The contribution of $\mathrm{G}$ proteins to the integrated DMR response of $\mathrm{hH}_{1-4} \mathrm{Rs}$ was investigated by pursuing two different approaches. Firstly, in a classical pharmacological approach the $G$ protein signaling pathways in $\mathrm{HEK} \mathrm{hH}_{1-4} \mathrm{R}$ cells were silenced using $\mathrm{G}$ protein modulators (PTX, CTX, FR and gallein). Secondly, in a molecular biological approach CRISPR/Cas 9 modified G $\alpha$ knock-out HEK cells $\left(\Delta \mathrm{G} \alpha_{\mathrm{x}} \mathrm{HEK}\right)$ lacking either the $\mathrm{G} \alpha_{\mathrm{s} / 1}\left(\Delta \mathrm{G} \alpha_{\mathrm{s} / 1} \mathrm{HEK}\right)$ [63], the $\mathrm{G} \alpha_{\mathrm{q} / 11}$ ( $\left.\Delta \mathrm{G} \alpha_{\mathrm{q} / 11} \mathrm{HEK}\right)$ [44] or the $\mathrm{G} \alpha_{12 / 13}\left(\Delta \mathrm{G} \alpha_{12 / 13} \mathrm{HEK}\right)$ [64] gene were stably transfected with $\mathrm{hH}_{1-4}$ Rs. Moreover, cells lacking six $\mathrm{G} \alpha$ proteins $\left(\Delta \mathrm{G} \alpha_{\mathrm{s} / 1, \mathrm{q} / 11,12 / 13}=\Delta \mathrm{G} \alpha_{\text {six }}\right.$ HEK) [41], stably expressing the $\mathrm{hH}_{1-4} \mathrm{Rs}$ were used. The results for both approaches were compared and discussed with respect to the impact of $\mathrm{G}$ protein inactivation on the $\mathrm{hH}_{1-4} \mathrm{R}$ mediated DMR response.

\section{Results and Discussion}

\subsection{Characterization of $\mathrm{HEK} h \mathrm{H}_{1-4} \mathrm{R}$ Cells}

To investigate the effect of endogenously expressed $G$ proteins on the DMR response, HEK $\mathrm{hH}_{1-4} \mathrm{R}$ cells were generated. For this purpose, the human histamine $\mathrm{H}_{1}, \mathrm{H}_{2}, \mathrm{H}_{3}$ or $\mathrm{H}_{4}$ receptor $\left(\mathrm{hH}_{1-4} \mathrm{Rs}\right)$ was inserted into a pIRESneo3 vector encoding the signaling peptide (SP) of the murine 5- $\mathrm{HT}_{3 \mathrm{~A}}$ receptor and a FLAG tag to give the pIRESneo3-SPFLAG-hH $H_{1-4} \mathrm{R}$ constructs. Both parental and $\Delta \mathrm{G} \alpha_{\mathrm{x}}$ HEK cells were stably transfected

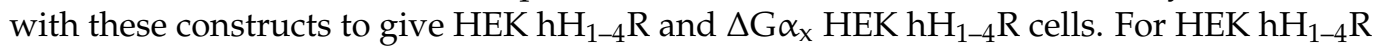
cells, single clones of the stable transfectants were picked, selected, and screened by DMR for the highest signal elicited by $100 \mu \mathrm{M}$ histamine (data not shown; (structure is presented in supplementary Figure S1). The expression of the $\mathrm{hH}_{1-4} \mathrm{Rs}$ in HEK cells was confirmed by radioligand saturation binding using live cells (Supplementary Figure S2). For the characterization of the $\Delta \mathrm{G} \alpha_{\mathrm{x}} \mathrm{HEK} \mathrm{hH}_{1-4} \mathrm{R}$ cells see Section 2.4.1 and supplementary Figure S3. The expression levels of $\mathrm{hH}_{1-4} \mathrm{Rs}$ in $\mathrm{HEK} \mathrm{hH}_{1-4} \mathrm{R}$ cells were calculated using $\mathrm{B}_{\max }$ and the specific activity $\left(\mathrm{a}_{\mathrm{s}}\right)$ of the corresponding radioligand and the cell number (Table 1). Despite identical receptor cloning and transfection procedures of the $\mathrm{hH}_{1-4} \mathrm{Rs}$, the expression level of $\mathrm{hH}_{3} \mathrm{R}$ and $\mathrm{hH}_{4} \mathrm{R}$ was lower compared to the $\mathrm{hH}_{1} \mathrm{R}$ and $\mathrm{hH}_{2} \mathrm{R}$. The $\mathrm{pK}_{\mathrm{d}}$ values determined for the respective radioligands at $\mathrm{HEK} \mathrm{hH}_{1-4} \mathrm{R}$ cells were in good agreement with literature data (Table 1).

To further characterize the $\mathrm{HEK}_{\mathrm{hH}} \mathrm{H}_{1-4} \mathrm{R}$ cells, radioligand competition binding experiments were performed with histamine (HIS) and one receptor-specific, inverse agonist (diphenhydramine (DPH) at the $\mathrm{hH}_{1} \mathrm{R}$, famotidine (FAM) at the $\mathrm{hH}_{2} \mathrm{R}$, pitolisant (PIT) at the $\mathrm{hH}_{3} \mathrm{R}$ and thioperamide (THIO) at the $\mathrm{hH}_{4} \mathrm{R}$ ) using live cells (structures are presented in supplementary Figure S1). The displacement curves are shown in supplementary Figure $\mathrm{S} 4$ and the $\mathrm{pK}_{\mathrm{i}}$ values are summarized in Table 2. As expected, HIS had a markedly higher affinity to $\mathrm{hH}_{3,4} \mathrm{Rs}$ compared to $\mathrm{hH}_{1,2} \mathrm{Rs}$ (Table 2). In the literature, $\mathrm{pK}_{\mathrm{i}}$ values were determined either with cell membranes/homogenates or with live cells. In general, the $\mathrm{pK}_{\mathrm{i}}$ values determined for HIS and the inverse agonists using $\mathrm{HEK}_{\mathrm{hH}} \mathrm{H}_{2-4} \mathrm{R}$ cells were in the same range as reported in the literature with live cells (Supplementary Table S1). To the best of our knowledge, $\mathrm{pK}_{\mathrm{i}}$ values for HIS at the $\mathrm{hH}_{1} \mathrm{R}$ in live cells have not yet been reported. Compared to reference values from membranes/homogenates ranging between 4.3-5.9 [65-67], the affinity of HIS for the $\mathrm{hH}_{1} \mathrm{R}$ was lower in live cells $\left(\mathrm{pK}_{\mathrm{i}}=3.37 \pm 0.29\right)$. 
The use of live cells in comparison to membrane preparations has a marked influence of the "apparent affinity" of ligands, especially in the case of agonists [68].

Table 1. Radioligand saturation binding data determined with live $H E K h H_{1-4} \mathrm{R}$ and $\Delta \mathrm{G} \alpha_{\mathrm{x}} \mathrm{HEK} h \mathrm{H}_{1-4} \mathrm{R}$ cells using $\left[{ }^{3} \mathrm{H}\right] \mathrm{MEP},\left[{ }^{3} \mathrm{H}\right] \mathrm{UR}-\mathrm{DE} 257$ or $\left[{ }^{3} \mathrm{H}\right] \mathrm{UR}-\mathrm{PI} 294$ as radiolabeled tracers for $\mathrm{hH}_{1} \mathrm{R}, \mathrm{hH}_{2} \mathrm{R}$ or $\mathrm{hH}_{3,4} \mathrm{R}$, respectively.

\begin{tabular}{|c|c|c|c|c|c|}
\hline G Protein Knock-Out $(\Delta)$ & HR & Binding Sites/Cell & $\mathrm{pK}_{\mathrm{d}}$ & $n$ & pK $_{\mathrm{d}}$ Ref. \\
\hline none & $\mathrm{hH}_{1} \mathrm{R}$ & $2.50 \times 10^{6}+0.52 \times 10^{6}$ & $8.32+0.08$ & 4 & $8.36^{\mathrm{a}}$ \\
\hline$\Delta \mathrm{G} \alpha_{\mathrm{s} / 1}$ & $\mathrm{hH}_{1} \mathrm{R}$ & $6.16 \times 10^{5}+2.07 \times 10^{5}$ & $8.42+0.04$ & 3 & \\
\hline$\Delta \mathrm{G} \alpha_{\mathrm{q} / 11}$ & $\mathrm{hH}_{1} \mathrm{R}$ & $1.78 \times 10^{5}+0.26 \times 10^{5}$ & $8.61+0.18$ & 3 & \\
\hline$\Delta \mathrm{G} \alpha_{12 / 13}$ & $\mathrm{hH}_{1} \mathrm{R}$ & $2.18 \times 10^{5}+0.04 \times 10^{5}$ & $8.46+0.08$ & 3 & \\
\hline$\Delta G \alpha_{\text {six }}$ & $\mathrm{hH}_{1} \mathrm{R}$ & \multicolumn{2}{|c|}{ Not detectable } & 3 & \\
\hline none & $\mathrm{hH}_{2} \mathrm{R}$ & $2.43 \times 10^{6}+0.23 \times 10^{6}$ & $7.19+0.06$ & 6 & $7.26^{b}$ \\
\hline$\Delta \mathrm{G} \alpha_{\mathrm{s} / 1}$ & $\mathrm{hH}_{2} \mathrm{R}$ & $1.68 \times 10^{6}+0.33 \times 10^{6}$ & $7.37+0.19$ & 3 & \\
\hline$\Delta \mathrm{G} \alpha_{\mathrm{q} / 11}$ & $\mathrm{hH}_{2} \mathrm{R}$ & $9.37 \times 10^{6}+0.63 \times 10^{6}$ & $7.40+0.06$ & 3 & \\
\hline$\Delta \mathrm{G} \alpha_{12 / 13}$ & $\mathrm{hH}_{2} \mathrm{R}$ & $3.94 \times 10^{6}+0.12 \times 10^{6}$ & $7.98+0.05^{* * * *}$ & 3 & \\
\hline$\Delta \mathrm{G} \alpha_{\text {six }}$ & $\mathrm{hH}_{2} \mathrm{R}$ & $4.23 \times 10^{6}+0.03 \times 10^{6}$ & $7.86+0.06^{* * *}$ & 3 & \\
\hline none & $\mathrm{hH}_{3} \mathrm{R}$ & $1.01 \times 10^{5}+0.21 \times 10^{5}$ & $8.61+0.03$ & 3 & $8.96^{\mathrm{c}}$ \\
\hline$\Delta \mathrm{G} \alpha_{\mathrm{s} / 1}$ & $\mathrm{hH}_{3} \mathrm{R}$ & $3.20 \times 10^{4}+0.83 \times 10^{4}$ & $8.71+0.11$ & 3 & \\
\hline$\Delta \mathrm{G} \alpha_{\mathrm{q} / 11}$ & $\mathrm{hH}_{3} \mathrm{R}$ & $3.94 \times 10^{4}+0.93 \times 10^{4}$ & $8.73+0.02$ & 2 & \\
\hline$\Delta \mathrm{G} \alpha_{12 / 13}$ & $\mathrm{hH}_{3} \mathrm{R}$ & $4.63 \times 10^{4}+1.32 \times 10^{4}$ & $8.49+0.10$ & 3 & \\
\hline$\Delta \mathrm{G} \alpha_{\text {six }}$ & $\mathrm{hH}_{3} \mathrm{R}$ & $1.01 \times 10^{5}+0.32 \times 10^{5}$ & $8.41+0.18$ & 3 & \\
\hline none & $\mathrm{hH}_{4} \mathrm{R}$ & $1.37 \times 10^{5}+0.18 \times 10^{5}$ & $8.45+0.05$ & 4 & $8.26^{\mathrm{d}}$ \\
\hline$\Delta \mathrm{G} \alpha_{\mathrm{s} / 1}$ & $\mathrm{hH}_{4} \mathrm{R}$ & $1.42 \times 10^{5}+0.33 \times 10^{5}$ & $8.26+0.07$ & 4 & \\
\hline$\Delta \mathrm{G} \alpha_{\mathrm{q} / 11}$ & $\mathrm{hH}_{4} \mathrm{R}$ & $1.24 \times 10^{5}+0.11 \times 10^{5}$ & $8.54+0.02$ & 3 & \\
\hline$\Delta \mathrm{G} \alpha_{12 / 13}$ & $\mathrm{hH}_{4} \mathrm{R}$ & $5.23 \times 10^{4}+0.42 \times 10^{4}$ & $8.55+0.06$ & 3 & \\
\hline$\Delta \mathrm{G} \alpha_{\text {six }}$ & $\mathrm{hH}_{4} \mathrm{R}$ & $1.06 \times 10^{5}+0.20 \times 10^{5}$ & $8.22+0.08$ & 4 & \\
\hline
\end{tabular}

Data is presented as means \pm SEM of at least three independent experiments, each performed in triplicate. Reference data was transformed

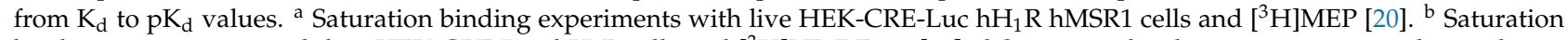
binding experiments with live HEK-CRE-Luc $\mathrm{hH}_{2} \mathrm{R}$ cells and $\left[{ }^{3} \mathrm{H}\right] \mathrm{UR}-\mathrm{DE} 257$ [69]. ${ }^{\mathrm{c}}$ Saturation binding experiments with membrane preparations of Sf9 insect cells co-expressing the $\mathrm{hH}_{3} \mathrm{R}+\mathrm{G} \alpha_{\mathrm{i}}+\mathrm{G} \beta \gamma$ and [ $\left.{ }^{3} \mathrm{H}\right] \mathrm{UR}-\mathrm{PI} 294$ [70]. d Saturation binding experiments with membrane preparations of Sf9 insect cells co-expressing the $\mathrm{hH}_{4} \mathrm{R}+\mathrm{G} \alpha_{\mathrm{i}}+\mathrm{G} \beta \gamma$ and [ $\left.{ }^{3} \mathrm{H}\right] \mathrm{UR}$-PI294 [70]. Statistical difference in $\mathrm{pK} \mathrm{K}_{\mathrm{d}}$ value

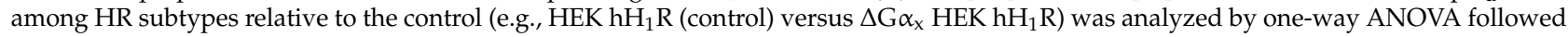
by Dunnett's multiple comparison test calculated as ${ }^{* * *} p \leq 0.001,{ }^{* * * *} p \leq 0.0001$.

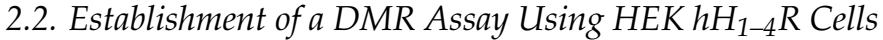

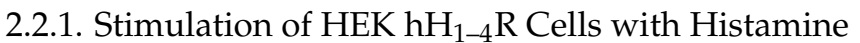

HEK $\mathrm{hH}_{1-4} \mathrm{R}$ cells were stimulated with increasing HIS concentrations and the DMR response was recorded for $60 \mathrm{~min}$. Positively deflected and concentration dependent DMR traces were observed for all four HR subtypes (Figure 2A), where both the signal maximum and the time course varied depending on the HR subtype. Of note, no DMR response was detected in non-transfected HEK wildtype (wt) cells, neither for HIS nor for inverse agonists (Supplementary Figure S6A), demonstrating that the ligand induced DMR

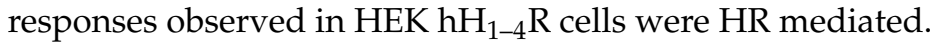

The highest amplitude and fastest increase in the DMR response was observed in HEK $\mathrm{hH}_{1} \mathrm{R}$ cells (1000 pm after $15 \mathrm{~min} ; 10 \mu \mathrm{M}$ HIS).

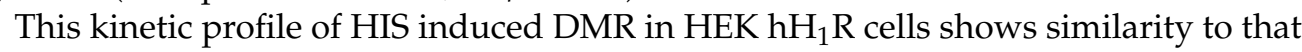
observed in HeLa cells, which express the $\mathrm{hH}_{1} \mathrm{R}$ endogenously [71]. In HeLa cells, the positive DMR showed a peak response of approx. $300 \mathrm{pm}$ within 3-5 min upon HIS addition, which decreased slightly and remained stable thereafter [71]. In A431 cells, which also express the $\mathrm{hH}_{1} \mathrm{R}$ endogenously, the positive DMR signal increased to a maximum value of approx. $500 \mathrm{pm}$ within approx. $5 \mathrm{~min}$ after addition of HIS [72]. Afterwards, the DMR signal decreased steadily to the level of the baseline [72]. A similar kinetic profile was observed previously in our group using genetically engineered HEK293T-CRELuc- $\mathrm{H}_{1} \mathrm{R}$-hMSR1 cells where the $\mathrm{hH}_{1} \mathrm{R}$ was co-expressed with the human macrophage scavenger receptor 1 (hMSR1), introduced to enhance the adhesion of HEK cells [20]. In 
HEK293T-CRE-Luc- $\mathrm{H}_{1} \mathrm{R}-\mathrm{hMSR} 1$ cells, the positive DMR peaked at approx. $600 \mathrm{pm}$ within 10 min after HIS addition and gradually decreased afterwards back to baseline [20,73]. These disparate kinetic profiles observed after stimulation of the $\mathrm{hH}_{1} \mathrm{R}$ with HIS were not surprising, as many characteristics of the different cell models used, e.g., receptor expression, expression patterns of $(\mathrm{G})$ proteins, and/or cell adhesion, can affect the kinetic profile of the DMR response [73,74]. When comparing the kinetics of HIS in $\mathrm{HEK} \mathrm{hH}_{1} \mathrm{R}$ cells with DMR traces of purinergic P2Y or muscarinic M3 receptors (both also G $\alpha_{\mathrm{q}}$ coupled and heterologously expressed in HEK cells) [44], no similarities were found.

A
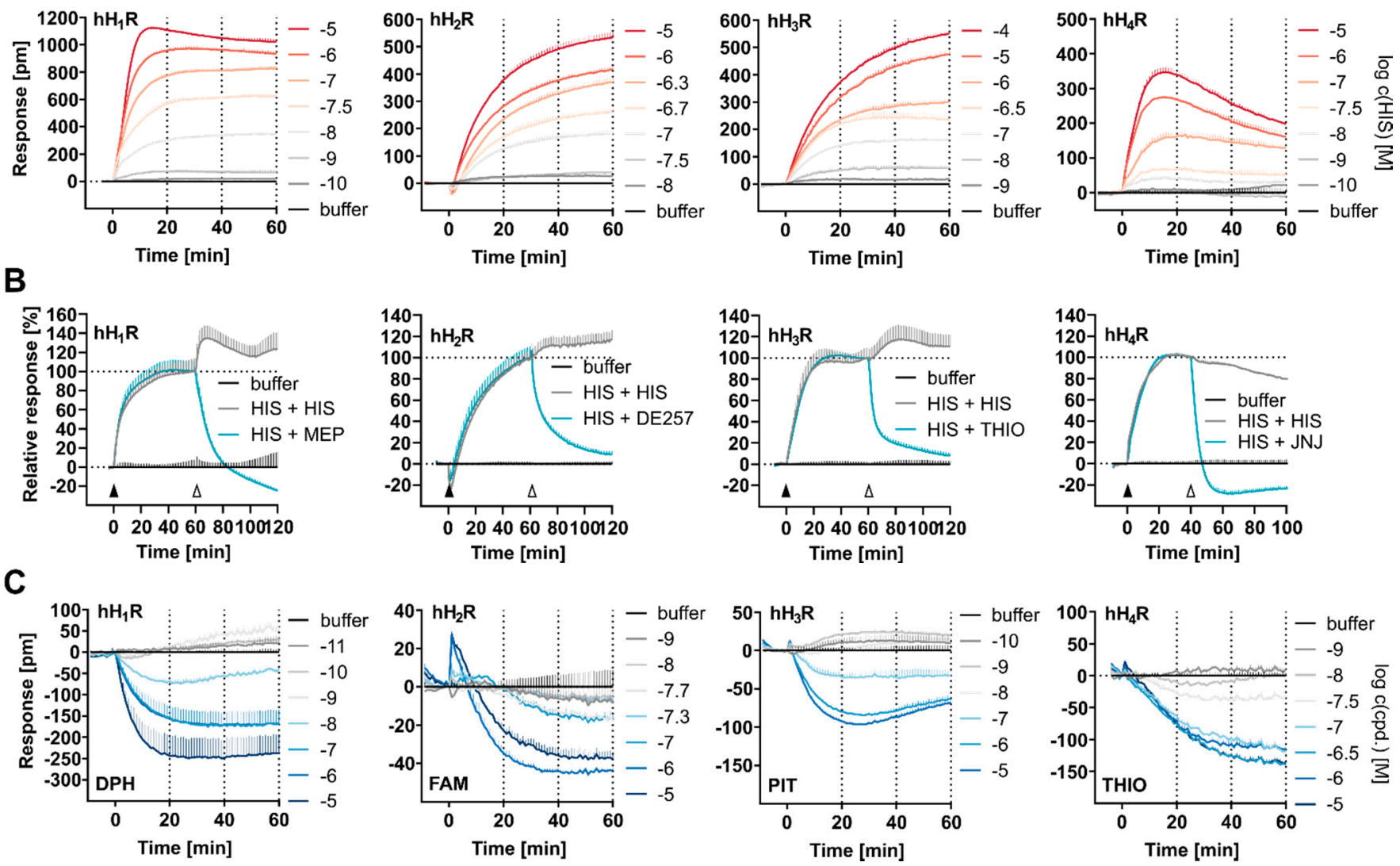

Figure 2. Implementation of the DMR assay for the $\mathrm{hH}_{1-4}$ Rs stably expressed in HEK cells. (A) Representative DMR traces recorded with $\mathrm{HEK} \mathrm{hH}_{1-4} \mathrm{R}$ cells upon stimulation with increasing concentrations of histamine. (B) The histamine induced DMR responses were reversible in $\mathrm{HEK} \mathrm{hH}_{1-4} \mathrm{R}$ cells. The $\mathrm{HEK} \mathrm{hH}_{1-4} \mathrm{R}$ cells were pre incubated with histamine at concentrations corresponding to the respective $\mathrm{pEC}_{80}$ value $\left(\mathrm{hH}_{1} \mathrm{R}=316 \mathrm{nM}, \mathrm{hH}_{2} \mathrm{R}=794 \mathrm{nM}, \mathrm{hH} \mathrm{H}_{3} \mathrm{R}=1995 \mathrm{nM}\right.$, $\mathrm{hH}_{4} \mathrm{R}=501 \mathrm{nM}$, indicated by the filled arrow $\mathbf{\Delta}$ ) and the DMR response was recorded for $60 \mathrm{~min}\left(\mathrm{hH} \mathrm{H}_{1-3} \mathrm{R}\right)$ or for $40 \mathrm{~min}$ $\left(\mathrm{hH}_{4} \mathrm{R}\right)$. Subsequently, a receptor specific antagonist was added $\left(\mathrm{hH}_{1} \mathrm{R} 10 \mu \mathrm{M} \mathrm{MEP}, \mathrm{hH}_{2} \mathrm{R} 10 \mu \mathrm{M}\right.$ DE257, $\mathrm{hH} \mathrm{H}_{3} \mathrm{R} 10 \mu \mathrm{M}$ THIO, $\mathrm{hH}_{4} \mathrm{R} 10 \mu \mathrm{M} \mathrm{JNJ}$, empty arrow $\triangle$ ) and the DMR was recorded for additional $60 \mathrm{~min}$. (C) Constitutive activity was detected in $\mathrm{HEK} \mathrm{hH}_{1-4} \mathrm{R}$ cells. Inverse agonism was observed at the $\mathrm{hH}_{1} \mathrm{R}$ for $\mathrm{DPH}$, at the $\mathrm{hH}_{2} \mathrm{R}$ for FAM, at the $\mathrm{hH} \mathrm{H}_{3} \mathrm{R}$ for $\mathrm{PIT}_{\text {, at the }}$ $\mathrm{hH}_{4} \mathrm{R}$ for THIO. Traces shown in (A-C) were corrected for the buffer and represent mean $\pm \mathrm{SEM}$ of the technical triplicate. Traces shown in (B) were additionally normalized to the value recorded after $60 \mathrm{~min}(100 \%)$.

Compared to HEK $\mathrm{hH}_{1} \mathrm{R}$ cells, the DMR response recorded for $\mathrm{HEK}_{\mathrm{hH}} \mathrm{R}$ and HEK $\mathrm{hH}_{3} \mathrm{R}$ cells were markedly different, showing no sharp maxima upon stimulation with HIS at a concentration of 10 or $100 \mu \mathrm{M}$ within $60 \mathrm{~min}$. Instead, the DMR signal increased slower, but steadily, reaching a highest amplitude ranging between 500-600 pm after $60 \mathrm{~min}$. A unique feature of the $\mathrm{hH}_{2} \mathrm{R}$ mediated DMR response was a slight signal dip (Zoom-in in supplementary Figure S5) immediately after HIS addition, a phenomenon that was not observed within this study for any other HR subtype under the same experimental conditions. A signal dip was also observed for the $\mathrm{G} \alpha_{\mathrm{s}}$ coupled GPCRs [29,37], e.g., EP2/4, 
which was stably expressed in HEK cells [37]. Ye Fang [29] explained such a signal dip by the fact that downstream signaling components involved in the signal transduction process are already compartmentalized and located at or near the cell membrane. Therefore, the recruitment of intracellular signal transduction components to activated receptors is less pronounced and other cellular signaling events are more salient leading to an initial decrease in local mass density [29]. However, one should be careful to interpret this as a reliable feature of $\mathrm{G} \alpha_{\mathrm{s}}$ coupling.

Although the $\mathrm{hH}_{2} \mathrm{R}$ is reported as $\mathrm{G} \alpha_{\mathrm{s}}$ coupled [57] and the $\mathrm{hH}_{3} \mathrm{R}$ is described as a $\mathrm{G} \alpha_{\mathrm{i} / \mathrm{o}}$ coupled receptor [57], the DMR traces recorded upon stimulation with HIS were similar in both signal amplitude and time course, except for the signal dip in the case of the $\mathrm{hH}_{2} \mathrm{R}$ (Figure 2A). This was surprising as we had expected that different $\mathrm{G}$ protein coupling would be associated with distinct DMR signaling profiles. Moreover, it was interesting that the signal amplitudes were similar because the expression level of the $\mathrm{hH}_{3} \mathrm{R}$ was approximately 20 -fold lower compared to that of $\mathrm{hH}_{2} \mathrm{R}$ (Table 1), conflicting with the assumption that the signal amplitude is positively correlated with the level of receptor expression. Instead, it can be speculated that the receptor-specific signal transduction pathway plays a role.

Even though both the $\mathrm{hH}_{3,4} \mathrm{Rs}$ are structurally related and considered as $\mathrm{G} \alpha_{\mathrm{i} / \mathrm{o}}$ coupled receptors (Figure 1B), the recorded DMR traces of $\mathrm{HEK} \mathrm{hH}_{3} \mathrm{R}$ and $\mathrm{hH}_{4} \mathrm{R}$ cells differed in both time course and signal amplitude (Figure 2A). Among the four human HR subtypes analyzed in this study, the lowest DMR response was recorded in $\mathrm{HEK}_{\mathrm{hH}} \mathrm{R}$ cells. The signal reached its maximum of approx. 300-400 pm within 10-20 min at the highest HIS concentration of $10 \mu \mathrm{M}$, and then declined continuously. Various $\mathrm{G} \alpha_{\mathrm{i} / \mathrm{o}}$ coupled receptors expressed in HEK cells (DP2 [41], CRTH2 [44]) or in CHO cells (NOP [75]) showed comparable kinetic profiles in DMR assays.

\subsubsection{Reversibility of HIS Induced DMR}

To demonstrate the reversibility of the DMR responses, $\mathrm{HEK} \mathrm{hH}_{1-4} \mathrm{R}$ cells were first treated with histamine at concentrations corresponding to the respective $\mathrm{pEC}_{80}$ value $\left(\mathrm{hH}_{1} \mathrm{R}=316 \mathrm{nM}, \mathrm{hH}_{2} \mathrm{R}=794 \mathrm{nM}, \mathrm{hH}_{3} \mathrm{R}=1995 \mathrm{nM}, \mathrm{hH}_{4} \mathrm{R}=501 \mathrm{nM}\right.$; indicated by the filled arrow in Figure 2B) and the DMR was recorded for 60 min with $\mathrm{HEK} \mathrm{hH}_{1,2,3} \mathrm{R}$ cells, or for 40 min with $\mathrm{HEK} \mathrm{hH}_{4} \mathrm{R}$ cells. In the second step, a receptor-specific antagonist was added (10 $\mu \mathrm{M}$ mepyramine (MEP) for $\mathrm{hH}_{1} \mathrm{R}, 10 \mu \mathrm{M}$ DE257 for $\mathrm{hH}_{2} \mathrm{R}, 100 \mu \mathrm{M}$ thioperamide (THIO) for $\mathrm{hH}_{3} \mathrm{R}$ and $10 \mu \mathrm{M}$ JNJ7777120 (JNJ) for $\mathrm{hH}_{4} \mathrm{R}$; indicated by the empty arrow in Figure 2B; structures of antagonists are presented in supplementary Figure S1). As a control, $\mathrm{HEK} \mathrm{hH}_{1-4} \mathrm{R}$ cells were also stimulated with $\mathrm{HIS}$, but in the second step, instead of an antagonist, HIS was added at a concentration corresponding to the $\mathrm{pEC}_{80}$. This was to ensure that the observed effect was induced by the antagonist and not by the addition procedure disturbing the system. For all four HR subtypes, the HIS-induced signal was suppressed by addition of a receptor subtype-specific antagonist, and no decrease in the signal was observed in the controls, showing reversibility of the DMR signal.

\subsubsection{Constitutive Activity}

Previously, all four HR subtypes have been reported as constitutively active in heterologous expression systems in canonical assays [23,76-81]. Constitutive (basal) activity describes the ability of GPCRs to produce a biological response in the absence of agonist binding by spontaneously adopting an active conformation [82]. Usually, the measurement of constitutive activity occurs by comparing the basal activity of a system comprising active-state receptors (e.g., transfected cells or high receptor expression) and without receptors (e.g., not transfected cell, low receptor expression) [83]. The basal activity should increase with increase in receptor expression. To assess the constitutive activity of HRs in the DMR assay we compared the DMR traces of the buffer controls (assay buffer w/o ligand) recorded for not transfected HEK cells with that recorded for $\mathrm{HEK} \mathrm{hH}_{1-4} \mathrm{R}$ cells (Supplementary Figure S7). After an equilibration period of about $40 \mathrm{~min}$, higher basal 
activity was measured in HEK $\mathrm{hH}_{1,3,4}$ Rs compared to not transfected HEK wt cells. We interpret this as an indication that the receptors in this system are constitutively active. However, no difference in the basal activity was observed between $\mathrm{HEK}_{\mathrm{hH}} \mathrm{R}$ cells and HEK wt cells (Supplementary Figure S7). This may imply that the $\mathrm{hH}_{2} \mathrm{R}$ is either not constitutively active in this system, or that this activity is too weak to be detected in this system. To explore measurement of inverse agonism by DMR, $\mathrm{HEK} \mathrm{hH}_{1-4} \mathrm{R}$ cells were stimulated with a receptor specific inverse agonist $\left(\mathrm{hH}_{1} \mathrm{R}: \mathrm{DPH}, \mathrm{hH}_{2} \mathrm{R}\right.$ : FAM, $\left.\mathrm{hH}_{3} \mathrm{R}: \mathrm{PIT}, \mathrm{hH}_{4} \mathrm{R}: \mathrm{THIO}\right)$ at increasing concentrations. Constitutive activity, manifesting as negatively deflected DMR traces, was observed at all four receptor subtypes, differing in intensity depending on the HR-ligand combination. (Figure 2C). The weakest inverse activity was measured for the $\mathrm{hH}_{2} \mathrm{R}$ when stimulated with FAM. This implies that the $\mathrm{hH}_{2} \mathrm{R}$ is constitutively active, but much lower compared to $\mathrm{hH}_{1,3,4} \mathrm{R}$. We previously anticipated this to be the case in view of supplementary Figure S7. We can rule out off-target effects for any HR-ligand combination, as none of the ligands elicited a DMR response in not transfected HEK wt cells (Supplementary Figure S6A).

\subsubsection{Assay Quality}

For data analysis, the area under curve (AUC) was calculated for the DMR traces, which is a commonly applied concept for the assessment of dynamic pharmacological processes $[38,73]$. Compared to single point measurements, the integration over time provides a more accurate estimate of the overall response to a drug [84]. To assess assay quality, signal-to-background (S/B) ratios were estimated based on AUC over the entire measurement period of $60 \mathrm{~min}\left(\mathrm{AUC}_{60}\right)$ for both $\mathrm{HIS}$ and a respective inverse agonist using $\mathrm{HEK} \mathrm{hH}_{1-4} \mathrm{R}$ cells. We are aware that the calculation of the S/B ratio using AUC appears problematic as the DMR signal does not represent an absolute measure, but rather a shift of the wavelength relative to the baseline. To alleviate this problem, we considered the stable baseline as the zero point and used the modulus of AUC for the estimation of the S/B ratio. This approximation is possible because the EnSpire software records and uses the last measuring point (repeat) in the baseline run as the calibration offset, which is subtracted from all repeats of the baseline and the final record (last repeat in the baseline was set to zero) [85].

For HIS, high S/B ratios were determined at the $\mathrm{hH}_{1} \mathrm{R}, \mathrm{hH}_{2} \mathrm{R}, \mathrm{hH}_{3} \mathrm{R}$ and $\mathrm{hH}_{4} \mathrm{R}$, amounting to $308,277,218$ and 123, respectively (Figure 3). Compared to HIS, the S/B ratios for the standard inverse agonists were markedly lower (S/B ratios: $\mathrm{DPH}\left(\mathrm{hH}_{1} \mathrm{R}\right)=53$, FAM $\left(\mathrm{hH}_{2} \mathrm{R}\right)=33$, PIT $\left(\mathrm{hH}_{3} \mathrm{R}\right)=25$ and THIO $\left.\left(\mathrm{hH}_{4} \mathrm{R}\right)=30\right)$ as shown in Figure 3. In comparison, $\mathrm{S} / \mathrm{B}$ ratios for HIS in $\left[{ }^{35} \mathrm{~S}\right] \mathrm{GTP} \gamma \mathrm{S}$ or miniG assays ranged from 2 to 30 [80]. Among other factors, high S/B ratios are beneficial for signal deconvolution studies, assessing efficacies and potencies of ligands, and investigating constitutive activities of receptors.

\subsubsection{Conversion of the DMR Responses to Concentration-Response-Curves (CRCs)}

The optical traces (representations in Figure 2A, C) were converted to CRCs by calculating the $\mathrm{AUC}_{60}$ and plotting these values against the logarithmic concentrations of a compound (Figure $4 \mathrm{~A}$ ). The determined $\mathrm{pEC}_{50}$ and $\mathrm{E}_{\max }$ values are summarized in Table 2. However, when calculating the S/B ratios, a slight dependency on the time interval used for the AUC calculations was observed (described in SM Text S1, Impact of the time interval used for calculations of AUC on S/B ratios, supplementary Figure S8 and supplementary Table S3). Moreover, a time-dependent potency of agonists was observed at the muscarinic $\mathrm{M}_{3}$ [86] and the neurotensin $\mathrm{NTS}_{1}$ [53] receptor in DMR assays. Therefore, we investigated whether the time interval used to calculate the AUC had an impact on the $\mathrm{pEC}_{50}$ and $\mathrm{E}_{\max }$ values of HIS and the receptor specific inverse agonists. 

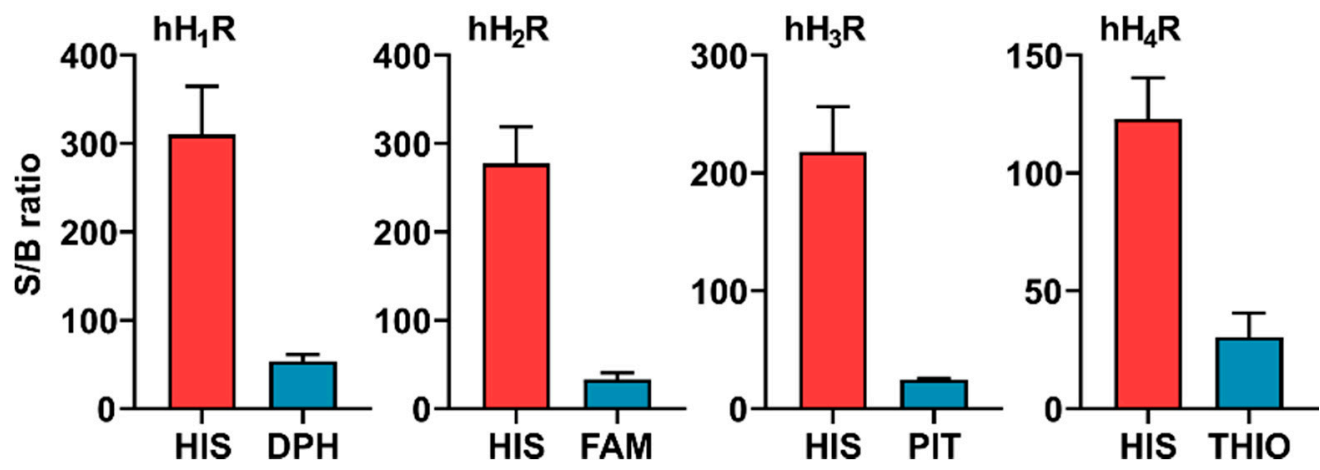

Figure 3. Signal-to-background (S/B) ratios estimated for HIS and inverse agonists using HEK $\mathrm{hH}_{1-4} \mathrm{R}$ cells. For the estimation of $\mathrm{S} / \mathrm{B}$ values, the modulus of area under curve $\left(\mathrm{AUC}_{60}\right)$ was calculated for the highest concentrations of HIS $\left(10 \mu \mathrm{M}\right.$ in $\mathrm{HEK}_{\mathrm{hH}} \mathrm{H}_{1,2,4} \mathrm{R}$ cells and $100 \mu \mathrm{M}$ in HEK $\mathrm{hH}_{3} \mathrm{R}$ cells) and the respective inverse agonist $\left(10 \mu \mathrm{M}\right.$ DPH in $\mathrm{HEK}_{\mathrm{hH}} \mathrm{R}$ cells, $10 \mu \mathrm{M}$ FAM in HEK $\mathrm{hH}_{2} \mathrm{R}$ cells, $10 \mu \mathrm{M}$ PIT in HEK $\mathrm{hH}_{3} \mathrm{R}$ cells, $100 \mu \mathrm{M}$ THIO in $\mathrm{HEK} \mathrm{hH}_{4} \mathrm{R}$ cells), and divided by the respective $\mathrm{AUC}_{60}$ value determined for the buffer. For HIS, the positive AUC (above baseline) was used, whereas for the inverse agonists the negative AUC (below baseline) was calculated. The S/B ratios are presented as mean \pm SEM from at least three independent experiments, each performed in triplicate.

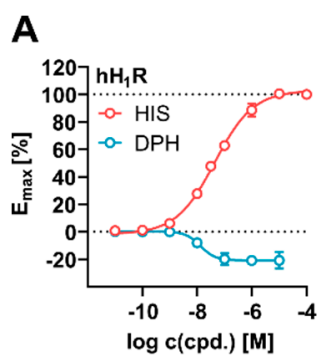

B

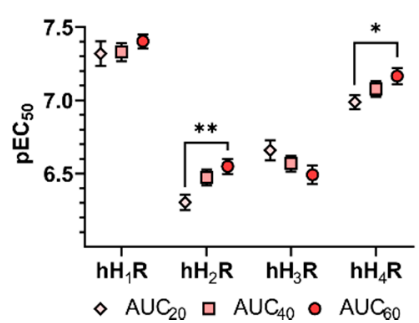

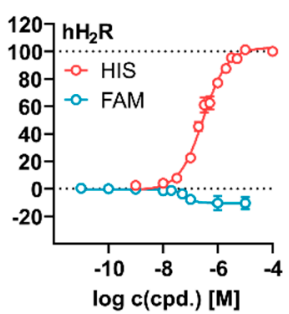

C

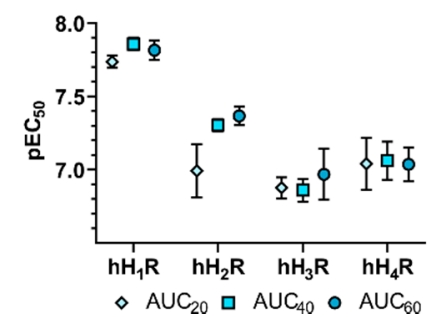

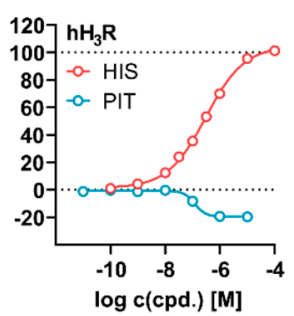

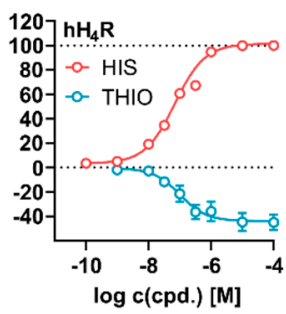

D

Figure 4. Analysis of DMR responses elicited by HIS (red) and inverse agonists (blue) in HEK $\mathrm{hH}_{1-4} \mathrm{R}$ cells. (A) CRCs determined for HIS and indicated inverse agonists at the $\mathrm{hH}_{1-4} \mathrm{Rs}$ using $\mathrm{AUC}_{60}$. The $\mathrm{E}_{\max }$ values determined for the inverse agonists wee normalized to the highest histamine concentration applied for the respective receptor subtype. (B) $\mathrm{pEC}_{50}$ values for HIS resulting from CRCs constructed by using $\mathrm{AUC}_{20}, \mathrm{AUC}_{40}$ or $\mathrm{AUC}_{60}$ at the $\mathrm{hH}_{1-4}$ Rs. (C) $\mathrm{pEC}_{50}$ values calculated for inverse agonists (DPH at the $\mathrm{hH}_{1} \mathrm{R}, \mathrm{FAM}$ at the $\mathrm{hH}_{2} \mathrm{R}$, PIT at the $\mathrm{hH}_{3} \mathrm{R}$ and THIO at the $\mathrm{hH}_{4} \mathrm{R}$ ) resulting from CRCs constructed by using $\mathrm{AUC}_{20}, \mathrm{AUC}_{40}$ or $\mathrm{AUC}_{60}$ at the $\mathrm{hH}_{1-4}$ Rs. (D) $\mathrm{E}_{\max }$ values determined for DPH at the $\mathrm{hH}_{1} \mathrm{R}, \mathrm{FAM}$ at the $\mathrm{hH}_{2} \mathrm{R}$, PIT at the $\mathrm{hH}_{3} \mathrm{R}$ and THIO at the $\mathrm{hH}_{4} \mathrm{R}$ using the $\mathrm{AUC}_{20}, \mathrm{AUC}_{40}$ or $\mathrm{AUC}_{60}$. $\mathrm{E}_{\text {max }}$ values were normalized to the highest HIS concentration applied for the corresponding HR subtype. (A-D) All values are means \pm SEM of at least three independent experiments, each performed in triplicate. Statistical difference relative to $\mathrm{AUC}_{60}$ was analyzed by one-way ANOVA followed by Dunnett's multiple comparison test calculated as ${ }^{*} p \leq 0.05,{ }^{* *} p \leq 0.01$.

For this purpose, additional CRCs were constructed using AUC calculations after 20 or 40 min $\left(\mathrm{AUC}_{20,40}\right)$ and compared to those from $\mathrm{AUC}_{60}$ (Supplementary Figure S9 and supplementary Table 44$)$. For $\mathrm{HEK} \mathrm{hH}_{1} \mathrm{R}$ cells, the time interval had no impact on 
the mean $\mathrm{pEC}_{50}$ values for HIS (Figure 4B). By contrast, in $\mathrm{HEK} \mathrm{hH}_{2} \mathrm{R}$ and $\mathrm{hH}_{4} \mathrm{R}$ cells a significant increase in $\mathrm{pEC}_{50}$ values from $A \mathrm{AC}_{20}$ to $A U C_{60}$ was observed for $\mathrm{HIS}\left(\mathrm{hH}_{2} \mathrm{R}\right.$ : from $6.30 \pm 0.05$ to $6.57 \pm 0.05 ; \mathrm{hH}_{4} \mathrm{R}$ : from $6.99 \pm 0.05$ to $7.15 \pm 0.05$, respectively), whereas in HEK $\mathrm{hH}_{3} \mathrm{R}$ a gradual decrease in mean $\mathrm{pEC}_{50}$ values was observed from $\mathrm{AUC}_{20}$ to $\mathrm{AUC}_{60}$ (from $6.66 \pm 0.07$ to $6.49 \pm 0.06$ ), which, however, was statistically not significant. For inverse agonists, the calculation of AUC after 20, 40 and $60 \mathrm{~min}$ had no significant impact on the mean $\mathrm{pEC}_{50}$ values (Figure $4 \mathrm{C}$ ). Signal transduction of GPCRs involves a complex network of different spatially and temporally resolved events, each of which show individual kinetics and/or amplitudes [53,86,87]. As all this information is bundled in the DMR response, it was not surprising that the temporal component could have an impact on the $\mathrm{pEC}_{50}$ and $\mathrm{E}_{\max }$ value depending on the specific signaling cascade triggered by the receptor ligand interaction. The $\mathrm{E}_{\max }$ values gradually decreased from $\mathrm{AUC}_{20}$ to $\mathrm{AUC}_{60}$ for all four HR-inverse agonist combinations (Figure $4 \mathrm{D}$; exact values in supplementary Table S4) but particularly for THIO at $\mathrm{hH}_{4} \mathrm{R}$, where the mean $\mathrm{E}_{\max }$ value showed a significant decrease from $\mathrm{AUC}_{20}$ to $\mathrm{AUC}_{60}\left(\mathrm{E}_{\max }\left(\mathrm{AUC}_{20}\right)=-20.1 \pm 5.0\right.$ to $\left.E_{\max }\left(A U C_{60}\right)=-45.0 \pm 5.7\right)$. The slow kinetics of the DMR response recorded for the inverse agonists can be considered as an explanation here (Figure 2A (HIS) versus Figure 2C (inverse agonists). In view of these results, the inclusion of the entire kinetic information $\left(\mathrm{AUC}_{60}\right)$ appears preferable and was considered as the standard method to calculate $\mathrm{pEC}_{50}$ and $\mathrm{E}_{\max }$ values in the following experiments.

\subsubsection{Functional Characterization of (Inverse) Agonists: Label-Free DMR versus Label-Dependent Techniques}

There was a discrepancy between competition binding and DMR functional data determined for HIS using HEK $\mathrm{hH}_{1,2} \mathrm{R}$ cells (Table 2). The $\mathrm{pK}_{\mathrm{i}}$ values for HIS in live cells were approximately $4\left(\mathrm{hH}_{1} \mathrm{R}\right)$ or $2\left(\mathrm{hH}_{2} \mathrm{R}\right)$ orders of magnitude lower compared to the $\mathrm{pEC}_{50}$ values in the DMR assay. Moreover, a discrepancy between affinity and potency was observed for pitolisant (PIT) at the $\mathrm{hH}_{3} \mathrm{R}$, where the $\mathrm{pK}_{\mathrm{i}}$ value was about 2 orders of magnitude larger compared to the $\mathrm{pEC}_{50}$ value in the DMR assay. As binding data reflect the strength of the receptor-ligand interaction, whereas functional responses are amplified translations of the receptor-ligand interaction, differences in this range are not uncommon and have been reported for example, for dopamine receptors [88]. We have previously stimulated HEK293T-CRE-Luc-hH $\mathrm{H}_{1} \mathrm{R}-\mathrm{hMSR} 1$ cells with HIS at increasing concentrations in the DMR assay [20]. The CRCs from $\mathrm{AUC}_{40}$ revealed a $\mathrm{pEC}_{50}$ value of 7.49 [20], which agrees with the result reported here $\left(\mathrm{pEC}_{50}=7.38 \pm 0.05\right)$.

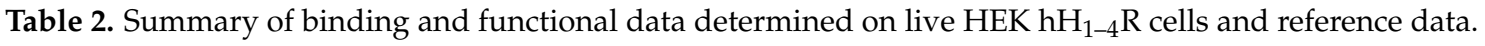

\begin{tabular}{|c|c|c|c|c|c|c|c|c|}
\hline \multirow[b]{3}{*}{ Rcptr. } & \multirow[b]{3}{*}{ Cpd. } & \multicolumn{3}{|c|}{ Determined } & \multicolumn{4}{|c|}{ References } \\
\hline & & \multirow{2}{*}{$\frac{\text { Comp Bdg }}{\mathrm{pK}_{\mathrm{i}}}$} & \multicolumn{2}{|c|}{ DMR } & \multicolumn{2}{|c|}{ miniG Recruitment [80] } & \multicolumn{2}{|c|}{ Luciferase Reporter Gene } \\
\hline & & & $\mathrm{pEC}_{50}$ & $\mathrm{E}_{\max }$ & $\mathrm{pEC}_{50} /\left(\mathrm{pK} \mathrm{K}_{\mathrm{b}}\right)$ & $\mathrm{E}_{\max }$ & $\mathrm{pEC}_{50} /\left(\mathrm{pK} \mathrm{K}_{\mathrm{b}}\right)$ & $\mathrm{E}_{\max }$ \\
\hline \multirow{2}{*}{$\mathrm{hH}_{1} \mathrm{R}$} & HIS & $3.37 \pm 0.29$ & $7.38 \pm 0.05$ & 100 & $6.16 \pm 0.09$ & 100 & $6.87 \pm 0.06[20]$ & $100[20]$ \\
\hline & $\mathrm{DPH}$ & $7.80 \pm 0.17$ & $7.82 \pm 0.07$ & $-22 \pm 3$ & $6.95 \pm 0.04$ & $-4 \pm 0.1$ & $(7.66 \pm 0.24)[20]$ & - \\
\hline \multirow{2}{*}{$\mathrm{hH}_{2} \mathrm{R}$} & HIS & $4.32 \pm 0.38$ & $6.57 \pm 0.05$ & 100 & $6.94 \pm 0.05$ & 100 & $6.49 \pm 0.27$ & 100 \\
\hline & FAM & $7.75 \pm 0.33$ & $7.37 \pm 0.06$ & $-10 \pm 5$ & $7.29 \pm 0.10$ & $-9 \pm 0.7$ & $7.47 \pm 0.15$ & n.d. \\
\hline \multirow{2}{*}{$\mathrm{hH}_{3} \mathrm{R}$} & HIS & $6.80 \pm 0.19$ & $6.49 \pm 0.06$ & 100 & $6.47 \pm 0.04$ & 100 & $8.48 \pm 0.09[89]$ & $100[89]$ \\
\hline & PIT & $8.72 \pm 0.05$ & $7.02 \pm 0.22$ & $-21 \pm 2$ & $(8.41 \pm 0.05)$ & - & n. d. & n. d. \\
\hline \multirow{2}{*}{$\mathrm{hH}_{4} \mathrm{R}$} & HIS & $7.25 \pm 0.05$ & $7.15 \pm 0.05$ & 100 & $6.40 \pm 0.04$ & 100 & $7.77 \pm 0.12[23]$ & $100[23]$ \\
\hline & THIO & $6.66 \pm 0.12$ & $7.04 \pm 0.14$ & $-45 \pm 6$ & $6.68 \pm 0.04$ & $-8 \pm 1.9$ & $6.92 \pm 0.10[23]$ & $-32.0 \pm 0.04$ \\
\hline
\end{tabular}

Competition binding (Comp. Bdg): The pKi values for histamine (HIS), diphenhydramine (DPH), famotidine (FAM), pitolisant (PIT) and thioperamide (THIO) were determined with live $\mathrm{HEK} \mathrm{hH}_{1-4} \mathrm{R}$ cells in the presence of $5 \mathrm{nM}\left[{ }^{3} \mathrm{H}\right]$ mepyramine $\left(\left[{ }^{3} \mathrm{H}\right] \mathrm{MEP}\right)$ at the $h \mathrm{H}_{1} \mathrm{R}$, $50 \mathrm{nM}\left[{ }^{3} \mathrm{H}\right] \mathrm{UR}-\mathrm{DE} 257$ at the $\mathrm{hH}_{2} \mathrm{R}, 2 \mathrm{nM}$ or $5 \mathrm{nM}\left[{ }^{3} \mathrm{H}\right] \mathrm{UR}-\mathrm{PI} 294$ at the $\mathrm{hH}_{3} \mathrm{R}$ or $\mathrm{hH}_{4} \mathrm{R}$, respectively. DMR: The $\mathrm{pEC} \mathrm{C}_{50}$ and $\mathrm{E}_{\max }$ values were determined by converting the DMR traces to CRCs using the positive $\mathrm{AUC}_{60}$ for HIS or the negative $\mathrm{AUC}_{60}$ for the inverse agonists (DPH at the $\mathrm{hH}_{1} \mathrm{R}, \mathrm{FAM}$ at the $\mathrm{hH}_{2} \mathrm{R}$, PIT at the $\mathrm{hH}_{3} \mathrm{R}$ and THIO at the $\left.\mathrm{hH}_{4} \mathrm{R}\right)$. These values were subsequently normalized to AUC 60 for the buffer $(0 \%)$ and the respective highest histamine concentration $(100 \%)$. The negative sign of $E_{\max }$ values for inverse agonists implies a negative deflection of the originate DMR traces (Figure 2C). All values represent means \pm SEM of at least three independent experiments, each performed in triplicate. $n$. d. means not determined. 
To the best of our knowledge, we are the first to report functional DMR data for the $\mathrm{hH}_{2-4} \mathrm{Rs}$, so no reference data was available. In order to compare the results, a miniG recruitment assay, recently implemented by Hoering et al. [80] for the entire HR family, was used. As the miniG recruitment assay was also performed with live HEK cells in real time, and the AUC used for data analysis, these results were particularly well suited as a reference. As a canonical alternative, a luciferase reporter gene assay was used. This assay was also performed with HEK cells but represents an endpoint measurement, in contrast to the kinetic measurements of DMR and miniG recruitment assays. Although the three assays measure different processes in the signal transduction cascade of HRs, in general, the $\mathrm{pEC}_{50}$ values were in good agreement, not differing more than one order of magnitude (Table 2). Exceptions are HIS at the $\mathrm{hH}_{1} \mathrm{R}$ (DMR vs. miniG) and $\mathrm{HIS}$ at the $\mathrm{hH}_{3} \mathrm{R}$ (DMR vs. luciferase). By contrast, higher discrepancies were observed regarding the efficacy of the inverse agonists. In general, inverse agonists were less efficacious in the miniG recruitment assay than in the DMR assay. However, as only one miniG protein-HR interaction was monitored rather than the holistic cellular response as in the DMR assay, this discrepancy is not surprising. A better agreement of $E_{\max }$ values was observed between the DMR and the luciferase reporter gene assay for THIO at the $\mathrm{hH}_{4} \mathrm{R}$.

\subsection{Dissecting HIS Induced DMR Signals in HEK $h H_{1-4} R$ Cells Using G Protein Modulators}

2.3.1. Impact of Individual G $\alpha$ Protein Modulators on the DMR Response

As outlined above, depending on the HR subtype, different intensities and time courses of the DMR responses were observed when $\mathrm{HEK}_{\mathrm{hH}} \mathrm{H}_{1-4} \mathrm{R}$ cells were stimulated with HIS at increasing concentrations (Figure 2A). We investigated whether the receptorspecific DMR response was exclusively the result of an activation of the primary $\mathrm{G} \alpha$ protein dependent signaling pathway described in the literature (Figure 1B), or whether additional $G$ proteins were involved in the HIS-induced DMR response. The contribution of endogenously expressed $\mathrm{G} \alpha$ proteins was analyzed using $\mathrm{G}$ protein pathway modulators FR900359 (FR), pertussis toxin (PTX), and cholera toxin (CTX; mechanisms for all three outlined in Figure 5A). CRCs were recorded for HIS in $\mathrm{HEK} \mathrm{hH}_{1-4} \mathrm{R}$ cells in the absence and presence of CTX, PTX (both at concentrations of 1.00, 10.0 and $100 \mathrm{ng} / \mathrm{mL}$ ) and FR (at concentrations of $0.01,0.10$ and $1.00 \mu \mathrm{M}$ ). In every experiment, $\mathrm{HEK} \mathrm{hH}_{1-4} \mathrm{R}$ cells stimulated with HIS without (w/o) modulators served as 100\% control. DMR traces recorded at the highest histamine concentration in the absence and presence of the respective modulator were compared (Figure 5B) and, as before, AUC $_{60}$ CRCs were constructed (Supplementary Figure $\mathrm{S10}$ ). The corresponding $\mathrm{E}_{\max }$ and $\mathrm{pEC}_{50}$ values are summarized in supplementary Figure S11.

\section{- $\mathrm{hH}_{1} \mathrm{R}$}

Because the $\mathrm{G} \alpha_{\mathrm{q} / 11}$ pathway is considered canonical for the $\mathrm{hH}_{1} \mathrm{R}[56,57]$, a strong decline of the DMR response was expected upon incubating the $\mathrm{HEK} \mathrm{hH}_{1} \mathrm{R}$ cells with the $\mathrm{G} \alpha_{\mathrm{q} / 11}$ modulator FR. When $\mathrm{HEK} \mathrm{hH}_{1} \mathrm{R}$ cells were treated with $1.00 \mu \mathrm{M}$ FR, the time course of the DMR signal for HIS was noticeably altered, but not with $0.01 \mu \mathrm{M}$ or $0.1 \mu \mathrm{M}$ FR (5B green traces). In the former case, no maximum was observed and the DMR response was slower. However, even the highest FR concentration of $1.00 \mu \mathrm{M}$ was not sufficient to eradicate the HIS DMR response (Figure 5B, green traces), although the $\mathrm{E}_{\max }$ value was reduced to $41 \pm 9.5 \%$ (Figure $6 \mathrm{~A}$ ). Likewise, Lieb et al. were also not able to completely suppress the HIS induced DMR in HEK293T-CRE-Luc- $\mathrm{hH}_{1} \mathrm{R}-\mathrm{hMSR} 1$ cells in the presence of 1.00 or $10.0 \mu \mathrm{M}$ FR [20]. For comparison, a concentration of $1.00 \mu \mathrm{M}$ FR was enough to completely disrupt the DMR response of the muscarinic $M_{3} R$, which solely couples to $\mathrm{G} \alpha_{\mathrm{q} / 11}$ [44]. Thus, we conclude that the failure to completely suppress the DMR signal was not due to insufficient FR concentration, but rather that the residual signal in $\mathrm{HEK} \mathrm{hH}_{1} \mathrm{R}$ cells comes from additional $(\mathrm{G})$ protein interactions. The significantly reduced $\mathrm{pEC}_{50}$ in the presence of $1.00 \mu \mathrm{M}$ FR $(6.81 \pm 0.15)$ could be caused by inactivation of the $\mathrm{G} \alpha_{\mathrm{q} / 11}$ protein abolishing the $\mathrm{G} \alpha_{\mathrm{q} / 11}$ positive modulation, an effect seen when the $\mathrm{G}$ protein stabilizes the active conformation of the receptor $[24,90]$. 
A

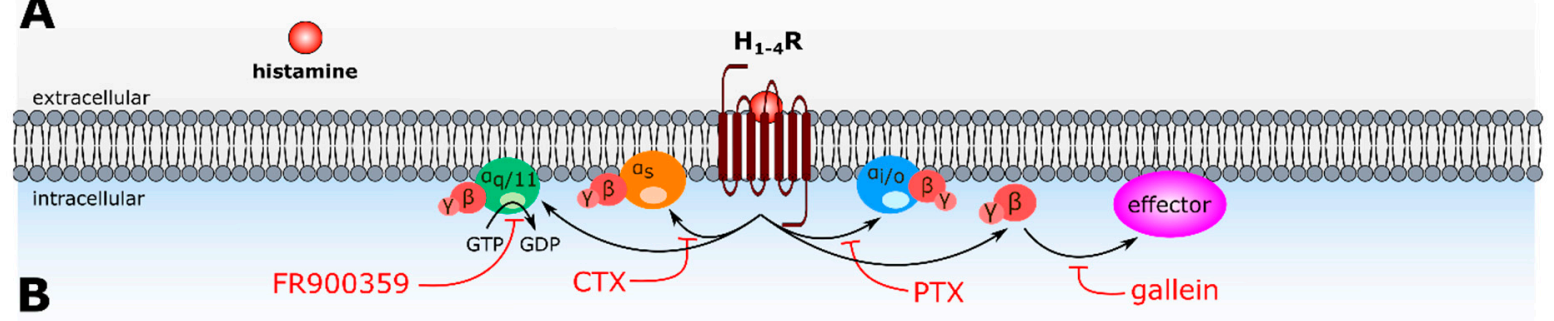

\section{$\mathrm{hH}_{\mathbf{1}} \mathrm{R}$}
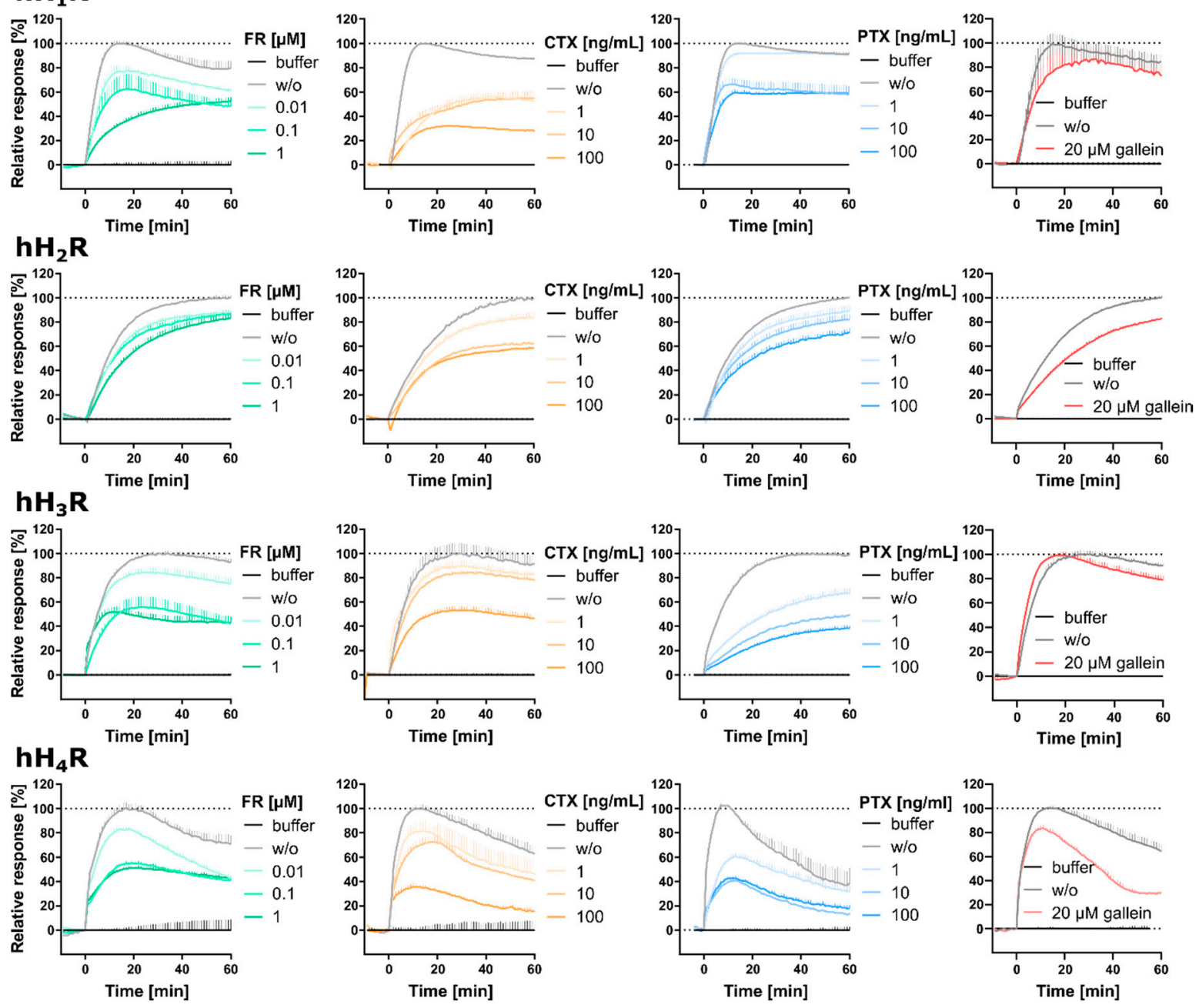

Figure 5. Effect of individual G protein modulators on the HIS induced DMR traces recorded in $\mathrm{HEK}_{\mathrm{hH}} \mathrm{H}_{1-4} \mathrm{R}$ cells. (A) Interference of the G protein modulators FR, CTX, PTX and gallein with histamine receptor mediated signaling. FR (alias UBO_QIC) selectively silences $\mathrm{G} \alpha_{\mathrm{q} / 11}$ signaling by blocking the GDP_release at concentrations 0.1 to $1.0 \mu \mathrm{M}[18,41,44-47]$. PTX selectively and irreversibly silences $\mathrm{G} \alpha_{\mathrm{i} / \mathrm{o}}$ at a concentration of $100 \mathrm{ng} / \mathrm{mL}$ by ADP_ribosylation at the $\mathrm{G} \alpha_{-}$subunit $[20,33,37,40-42]$. CTX locks the $\mathrm{G} \alpha_{\mathrm{s}}$ protein in its GTP bound state by irreversible ADP-ribosylation leading to a permanent activation of the $G \alpha_{s}$ protein, which is in turn uncoupled and no longer available for the GPCR [31-33,37,43] at a concentration of $100 \mathrm{ng} / \mathrm{mL}[31,32,37]$. As this approach only masks the G $\alpha_{\mathrm{s}}$ protein coupled pathway the results should be interpreted with caution. Gallein (gal) is reported to reversibly bind to the $G \beta \gamma$ subunit $\left(K_{d}=422 \mathrm{nM}\right)$ [92], preventing an interaction with effector proteins [92-94]. (B) Representative time courses of the HIS induced DMR response in $\mathrm{HEK}_{\mathrm{hH}} \mathrm{H}_{1-4} \mathrm{R}$ cells pre-treated with $\mathrm{G}$ protein modulator at the indicated concentrations overnight (PTX and CTX) or $30 \mathrm{~min}$ (FR and gallein) before measurement of stimulation with $\mathrm{HIS}\left(\mathrm{hH}_{1,2,4} \mathrm{R}\right.$ at $10 \mu \mathrm{M} \mathrm{HIS,}, \mathrm{hH}_{3} \mathrm{R}$ at $100 \mu \mathrm{M}$ HIS). All traces were buffer-corrected and normalized to the maximum DMR response (wavelength shift in $\mathrm{pm}$ ) of the untreated control (w/o). Data are presented as mean \pm SEM of a technical triplicate. 
Surprisingly, masking of the $\mathrm{G} \alpha_{\mathrm{S}}$ signaling pathway with CTX had a greater effect on the DMR response of the $\mathrm{hH}_{1} \mathrm{R}$ (Figure 5B, orange traces) than FR. Even the lowest concentration of $1.00 \mathrm{ng} / \mathrm{mL}$ CTX enormously altered both the maximum amplitude, and the time course of the HIS induced DMR response. In this case, the DMR response was slowed down and showed no signal maximum as observed for untreated $\mathrm{HEK} \mathrm{hH}_{1} \mathrm{R}$ cells. An increase in CTX concentration to $100 \mathrm{ng} / \mathrm{mL}$ further reduced the signal amplitude and led to a deceleration of the DMR signal. Unexpectedly, among the investigated modulators, $100 \mathrm{ng} / \mathrm{mL}$ CTX had the strongest effect on $\mathrm{E}_{\max }$ at the $\mathrm{hH}_{1} \mathrm{R}$ lowering the value to $23 \pm 4.9 \%$ (Figure $6 \mathrm{~A}$ ), suggesting that the $\mathrm{G} \alpha_{\mathrm{s}}$ protein is involved in the $\mathrm{hH}_{1} \mathrm{R}$ mediated DMR signal. Indeed, it has been shown that the $\mathrm{hH}_{1} \mathrm{R}$ can functionally interact with the $\mathrm{G} \alpha_{\mathrm{s}}$ protein in HEK cells overexpressing both the receptor and the $\mathrm{G} \alpha_{\mathrm{s}}$ protein $[60,91]$. The inhibition of $\mathrm{G} \alpha_{\mathrm{s}}$ pathway led to a significant increase in the $\mathrm{pEC} \mathrm{C}_{50}$ value $(7.87 \pm 0.19$; Figure $6 \mathrm{~B}$ ). It is possible that the uncoupling of $\mathrm{G} \alpha_{\mathrm{s}}$ may have enhanced $\mathrm{G} \alpha_{\mathrm{q}}$ protein interaction with the $\mathrm{hH}_{1} \mathrm{R}$, or $\mathrm{G} \alpha_{\mathrm{s}}$ may even act as a negative modulator at $\mathrm{hH}_{1} \mathrm{R}$. Further investigations are necessary to determine the mechanism involved.

A

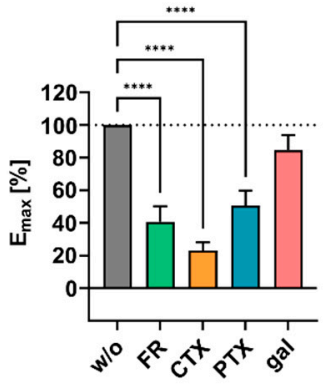

B

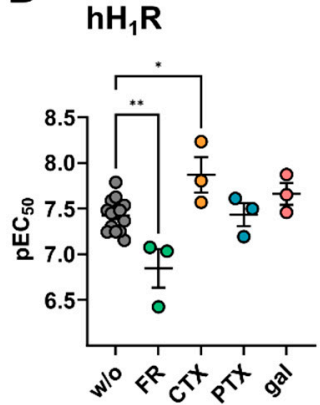

$\mathrm{hH}_{2} \mathrm{R}$

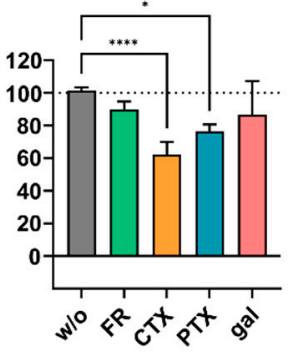

$\mathrm{hH}_{2} \mathrm{R}$

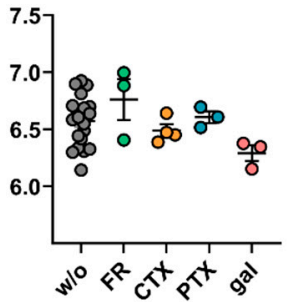

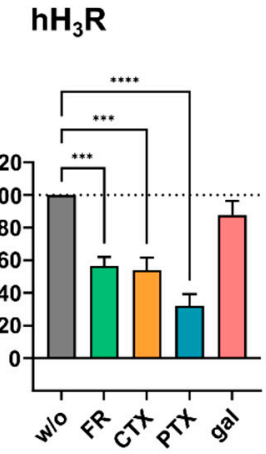

$\mathrm{hH}_{3} \mathrm{R}$

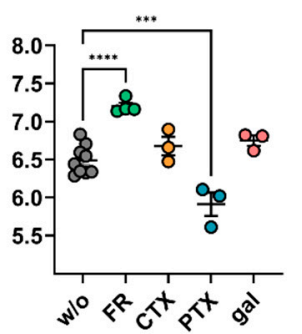

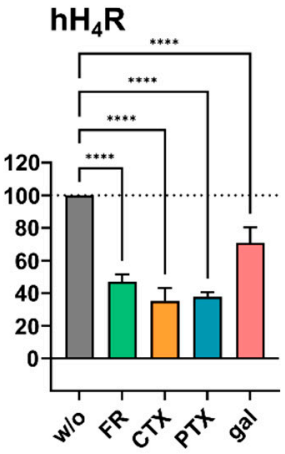

$\mathrm{hH}_{4} \mathrm{R}$

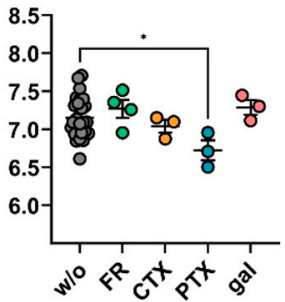

Figure 6. Effect of individual $\mathrm{G}$ protein modulators on the efficacy and potency of HIS at $\mathrm{hH}_{1-4} \mathrm{Rs}_{\text {. }}$ $\mathrm{E}_{\max }$ and $\mathrm{pEC}_{50}$ values were determined for HIS in the absence and the presence of $\mathrm{G}$ protein modulators. (A) Bar chart of $\mathrm{E}_{\max }$ values determined for HIS in absence (w/o, grey) and presence of FR (green, $1 \mu \mathrm{M}$ ), CTX (orange, $100 \mathrm{ng} / \mathrm{mL}$ ), PTX (blue, $100 \mathrm{ng} / \mathrm{mL}$ ) and gal (red, $20 \mu \mathrm{M}$ ). The $\mathrm{E}_{\max }$ values were calculated using $\mathrm{AUC}_{60}$ at the highest $\mathrm{HIS}$ concentration $\left(10 \mu \mathrm{M}\right.$ for $\mathrm{hH}_{1,2,4} \mathrm{R}$ and $100 \mu \mathrm{M}$ for $\left.\mathrm{hH}_{3} \mathrm{R}\right)$ and normalized to the $\mathrm{AUC}_{60}$ of the untreated control $(100 \%)$ and buffer $(0 \%)$ values. (B) Scatter plot of the $\mathrm{pEC}_{50}$ values in absence (grey) and presence of $\mathrm{G}$ protein modulators at the concentration stated above. The $\mathrm{pEC}_{50}$ were determined by plotting the $\mathrm{AUC}_{60}$ against the respective HIS concentration. (A,B) Data presented are means \pm SEM of at least three independent experiments, each performed in triplicate. Statistical difference relative to the control was analyzed by one-way ANOVA followed by Dunnett's multiple comparison test. Significance levels are indicated by asterisks $\left({ }^{*} p \leq 0.05,{ }^{* *} p \leq 0.01,{ }^{* * *} p \leq 0.001,{ }^{* * * *} p \leq 0.0001\right)$.

The inhibition of $\mathrm{G} \alpha_{\mathrm{i} / \mathrm{o}}$ signaling pathway with PTX reached its maximum effect at a concentration of $10.0 \mathrm{ng} / \mathrm{mL}$ at the $\mathrm{hH}_{1} \mathrm{R}$ (Figure $5 \mathrm{~B}$, blue traces). Except for decreasing the signal amplitude to maximum $50 \pm 9.3 \%$ of $\mathrm{E}_{\max }$ relative to control cells (Figure $6 \mathrm{~A}$ ), PTX 
had no effect on the time course of the DMR signal, suggesting $\mathrm{G} \alpha_{\mathrm{i} / \mathrm{o}}$ protein involvement in $\mathrm{hH}_{1} \mathrm{R}$ signal transduction. This is in good accordance with the literature $[20,59,61]$. For example, Lieb et al. showed that the $\mathrm{hH}_{1} \mathrm{R}$ also signals via $\mathrm{G} \alpha_{\mathrm{i} / \mathrm{o}}$ in the DMR assay using HEK293T-CRE-Luc-hH $\mathrm{H}_{1} \mathrm{R}-\mathrm{hMSR} 1$, as the DMR signal was completely abolished by $100 \mathrm{ng} / \mathrm{mL}$ PTX [20].

- $\mathrm{hH}_{2} \mathrm{R}$

Pretreatment of HEK $\mathrm{hH}_{2} \mathrm{R}$ cells with increasing CTX concentrations led to a gradual decrease in the signal amplitude relative to the untreated control, but, in contrast to HEK $\mathrm{hH}_{1} \mathrm{R}$ cells, did not alter the shape of the DMR time course (Figure $5 \mathrm{~B}$, orange traces). At $100 \mathrm{ng} / \mathrm{mL} \mathrm{CTX}, 62 \pm 7.7 \%$ of the $\mathrm{hH}_{2} \mathrm{R}$ signal was retained; a significant effect, but not as pronounced as with the other three HR subtypes (Figure $6 \mathrm{~A} ; \mathrm{hH}_{1} \mathrm{R} 23 \pm 4.9 \%, \mathrm{hH}_{3} \mathrm{R}$ $54 \pm 7.6 \%$ and $\mathrm{hH}_{4} \mathrm{R} 35 \pm 7.9 \%$ signal retention). This was unexpected, as the $\mathrm{hH}_{2} \mathrm{R}$ is commonly considered as a $\mathrm{G} \alpha_{\mathrm{s}}$-coupled receptor [56,95]. Furthermore, $100 \mathrm{ng} / \mathrm{mL}$ CTX have been shown to almost completely abolish the agonist induced DMR response of the $\mathrm{G} \alpha_{\mathrm{s}}$-sensitive $\beta_{2}$ adrenoreceptor $\left(\beta_{2} \mathrm{R}\right)$ expressed by different cell types endogenously or heterologously $[31,32,37]$. Moreover, the $\mathrm{pEC}_{50}$ value of HIS remained unaffected by the treatment with CTX (Figure 6B). We expected that uncoupling of the $\mathrm{G} \alpha_{\mathrm{s}}$ protein with CTX would negatively affect the $\mathrm{pEC}_{50}$ value of $\mathrm{HIS}$, as was the case with $\mathrm{hH}_{1} \mathrm{R}$ after the $\mathrm{G} \alpha_{\mathrm{q} / 11}$ protein was inactivated by FR. These data suggest that additional signaling pathways contribute to the DMR response in $\mathrm{HEK} \mathrm{hH}_{2} \mathrm{R}$ cells.

Apart from $\mathrm{G} \alpha_{\mathrm{s}}$, it is known that the $\mathrm{G} \alpha_{\mathrm{q} / 11}$ protein can play a considerable role in $\mathrm{H}_{2} \mathrm{R}$ signal transduction, dependent on the cellular background [56]. This was not confirmed in the DMR assay as the $G \alpha_{\mathrm{q} / 11}$ modulator FR was almost completely ineffective, even at a concentration of $1.00 \mu \mathrm{M}$ (Figure 5B green traces). Although a stepwise decline of the DMR response was observed with increasing PTX concentrations to investigate the involvement of $\mathrm{G} \alpha_{\mathrm{i} / \mathrm{o}}$ in the HIS induced DMR (Figure 5B blue traces), the effect was less pronounced than with $\mathrm{CTX}\left(\mathrm{E}_{\max }=77 \pm 4.2 \%\right.$ at $100 \mathrm{ng} / \mathrm{mL}$ PTX versus $\mathrm{E}_{\max }=62 \pm 7.7 \%$; Figure $\left.6 \mathrm{~A}\right)$. Strikingly, in contrast to the other three HR subtypes, the individual modulators FR, CTX and PTX, had little effect on the HIS induced DMR response in $\mathrm{HEK}_{\mathrm{hH}} \mathrm{R}$ cells. Two explanations can be considered. Firstly, silencing of one pathway may have caused the $\mathrm{hH}_{2} \mathrm{R}$ to switch to other pathways, indicating promiscuous signal transduction of the receptor. Secondly, these results may also indicate the involvement of other effectors, e.g., $\mathrm{G} \alpha_{\mathrm{z}}$ or $\mathrm{G} \alpha_{12 / 13}$ [59], in the $\mathrm{hH}_{2} \mathrm{R}$ mediated DMR response.

- $\mathrm{hH}_{3} \mathrm{R}$

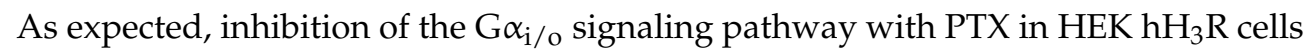
had a dramatic impact on the DMR response to $100 \mu \mathrm{M}$ HIS, for both the $E_{\max }$ and $\mathrm{pEC}_{50}$ values. Even $1.00 \mathrm{ng} / \mathrm{mL}$ of PTX was sufficient to decelerate the $\mathrm{hH}_{3} \mathrm{R}$ DMR response (Figure $5 \mathrm{~A}$, blue traces) and to reduce the $\mathrm{E}_{\max }$ to $63 \pm 14 \%$ (Figure $6 \mathrm{~A}$ ), roughly a $4 \times$ more reduction than for $\mathrm{hH}_{1,2} \mathrm{Rs}$. However, we failed to completely suppress the signal, as at $100 \mathrm{ng} / \mathrm{mL}$ PTX $32 \pm 7.2 \%$ of $\mathrm{E}_{\max }$ remained. By contrast, Shi et al. described that the HIS response was disrupted by $100 \mathrm{ng} / \mathrm{mL}$ of PTX in a CRE-driven luciferase activity assay using HEK cells stably expressing the $\mathrm{hH}_{3} \mathrm{R}$ [42]. Moreover, for other $\mathrm{G} \alpha_{\mathrm{i} / \mathrm{o}}$ coupled receptors, e.g., the muscarinic $\mathrm{M}_{2}$ [48], or prostaglandin $\mathrm{CRTH}_{2}$ [37], PTX at a concentration of $100 \mathrm{ng} / \mathrm{mL}$ was sufficient to completely disrupt the DMR signal in CHO or HEK cells. Thus, we expect that $100 \mathrm{ng} / \mathrm{mL}$ PTX was sufficient to inactivate $\mathrm{G} \alpha_{\mathrm{i} / \mathrm{o}}$ mediated signaling and conclude that other $(\mathrm{G})$ proteins were involved in the $\mathrm{hH}_{3} \mathrm{R}$ mediated DMR response. The $\mathrm{pEC}_{50}$ values declined with increasing PTX concentrations from $6.49 \pm 0.06$ (control) to $5.75 \pm 0.17$ and $5.91 \pm 0.15$ (10.0 and $100 \mathrm{ng} / \mathrm{mL}$ of PTX, respectively; Figure 6B). As described above, a similar phenomenon was observed for the $\mathrm{hH}_{1} \mathrm{R}$ when its canonical $\mathrm{G} \alpha_{\mathrm{q} / 11}$ signaling pathway was blocked with $1 \mu \mathrm{M}$ FR. We believe the same hypothesis to be true here, namely that the $\mathrm{G} \alpha_{\mathrm{i} / \mathrm{o}}$ protein stabilizes an active conformation of the $\mathrm{hH}_{3} \mathrm{R}$, resulting in decreased $\mathrm{pEC}_{50}$ values when blocked. Consistent with literature [57], this suggests that the $\mathrm{G} \alpha_{\mathrm{i} / \mathrm{o}}$ protein plays a major role in $\mathrm{hH}_{3} \mathrm{R}$ mediated signal transduction. 
However, as it was not possible to completely abrogate the DMR response with PTX, other $G$ protein (in)dependent signaling pathways might be involved as well.

The $\mathrm{G} \alpha_{\mathrm{q} / 11}$ modulator FR at increasing concentrations had no effect on the time course of the HIS induced DMR response, but did decrease the signal amplitude (Figure 5B, green traces). A decrease in $E_{\max }$ to about $95 \pm 5.3 \%$ was observed in the presence of $0.01 \mu \mathrm{M} F R$, whereas $0.10 \mu \mathrm{M}$ FR significantly reduced the $\mathrm{E}_{\max }$ value to $60 \pm 6.4 \%$. A ten-fold increase in FR concentration to $1.00 \mu \mathrm{M}$ decreased the $\mathrm{E}_{\max }$ by only additional $3 \%$ compared with $0.10 \mu \mathrm{M} F R$, indicating that at the latter concentration of FR the $\mathrm{G} \alpha_{\mathrm{q} / 11}$ dependent DMR was almost completely inhibited in $\mathrm{HEK} \mathrm{hH}_{3} \mathrm{R}$ cells (Figure 6A). Strikingly, the $\mathrm{pEC}_{50}$ value was significantly increased to $7.20 \pm 0.05$ after treatment with $1.00 \mu \mathrm{M}$ FR referring to the $\mathrm{pEC}_{50}$ of $6.49 \pm 0.06$ in control cells (Figure 6B). We did not expect this impact of $\mathrm{G} \alpha_{\mathrm{q} / 11}$ inhibition because hitherto the $\mathrm{hH}_{3} \mathrm{R}$ has been described as a $\mathrm{G} \alpha_{\mathrm{i} / \mathrm{o}}$ selective receptor and to date, no evidence has been provided that the $\mathrm{hH}_{3} \mathrm{R}$ is capable of activating a $\mathrm{G} \alpha$ protein other than $\mathrm{G} \alpha_{\mathrm{i} / \mathrm{o}}$ [91].

Masking the $G \alpha_{\mathrm{s}}$ signaling with CTX did not affect the time course of the HIS-induced $\mathrm{hH}_{3} \mathrm{R}$ mediated DMR response elicited by HIS, but again the signal amplitude was affected (Figure $5 \mathrm{~B}$ ). The $\mathrm{E}_{\max }$ values decreased to $77 \pm 9.0 \%$ or $76 \pm 6.3 \%$ after treatment with 1.00 or $10.0 \mathrm{ng} / \mathrm{mL}$ of CTX, respectively and was significantly reduced to $54 \pm 7.61 \%$ in the presence of $100 \mathrm{ng} / \mathrm{mL}$ CTX compared to control cells (Figure 6A). In comparison, the $\mathrm{E}_{\max }$ value at the $\mathrm{hH}_{1} \mathrm{R}$ was already reduced to $43 \pm 9.5 \%$ at a concentration of $1 \mathrm{ng} / \mathrm{mL}$ of CTX. Therefore, we reason that $\mathrm{G} \alpha_{\mathrm{s}}$ is not as involved in signal transduction at the $\mathrm{hH}_{3} \mathrm{R}$ as at the $\mathrm{hH}_{1} \mathrm{R}$. This assumption was further supported by the fact that the $\mathrm{pEC}_{50}$ value was not significantly affected by the treatment with CTX (Figure 6B).

- $\mathrm{hH}_{4} \mathrm{R}$

Pre-incubation of $\mathrm{HEK} \mathrm{hH}_{4} \mathrm{R}$ cells with PTX at increasing concentrations to block the $\mathrm{G} \alpha_{\mathrm{i} / \mathrm{o}}$ protein had no influence on the time course but did affect the signal amplitude of the HIS induced DMR response (Figure 5B). Similar to the $\mathrm{hH}_{3} \mathrm{R}$ response, even at $1 \mathrm{ng} / \mathrm{mL}$ PTX the $\mathrm{E}_{\max }$ was lowered to $51 \pm 6.8 \%$ (Figure $6 \mathrm{~A}$ ). However, we failed to completely displace the HIS induced DMR response at the $\mathrm{hH}_{4} \mathrm{R}$ by PTX, even at a concentration of $100 \mathrm{ng} / \mathrm{mL}$ (Figure $6 \mathrm{~A} ; \mathrm{E}_{\max }=38 \pm 2.9 \%$ ). Elsewhere, in a luciferase reporter gene assay with HEK293-EBNA cells transfected with the $\mathrm{hH}_{4} \mathrm{R}$ (referred to as GPRv53), $100 \mathrm{ng} / \mathrm{mL}$ PTX completely abolished the HIS induced response [96]. However, unlike the $\mathrm{hH}_{3} \mathrm{R}$ response, an increase in PTX concentration had no effect on $\mathrm{pEC}_{50}$ values in $\mathrm{HEK} \mathrm{hH}_{4} \mathrm{R}$ cells (Figure 6B).

The contribution of the $\mathrm{G} \alpha_{\mathrm{s}}$ protein was analyzed by pre-treating the cells with CTX at increasing concentrations. Figure $5 \mathrm{~B}\left(\mathrm{hH}_{4} \mathrm{R}\right.$ orange traces) shows that the maximum responses declined stepwise, whereas time courses of the HIS induced DMR remained unaltered (Figure 5B). Only at the highest CTX concentration of $100 \mathrm{ng} / \mathrm{mL}$, did the signal decrease substantially ( $E_{\max }=35 \pm 7.9 \%$; Figure $6 \mathrm{~A}$ ). Analogous to the $\mathrm{hH}_{3} \mathrm{R}$, we assume that $\mathrm{G} \alpha_{\mathrm{S}}$ is of smaller importance in the signal transduction of the $\mathrm{hH}_{4} \mathrm{R}$ compared to the $\mathrm{hH}_{1} \mathrm{R}$, where the $\mathrm{E}_{\max }$ value was reduced to $43 \pm 9.5 \%$ with $1 \mathrm{ng} / \mathrm{mL}$ CTX. Moreover, the $\mathrm{pEC}_{50}$ value for HIS in HEK $\mathrm{hH}_{4} \mathrm{R}$ cells was not affected in the presence of CTX (Figure 6B). The $\mathrm{G} \alpha_{\mathrm{q} / 11}$ modulator FR at increasing concentrations led to a stepwise decrease in the $\mathrm{hH}_{4} \mathrm{R}$ mediated DMR response. FR at a concentration of $0.10 \mu \mathrm{M}$ was sufficient to decrease the DMR signal to $71 \pm 18 \%$ relative to the untreated control, and a further decline was observed in the presence of $1.00 \mu \mathrm{M}$ FR ( $\mathrm{E}_{\max }=47 \pm 4.5 \%$; Figure $\left.6 \mathrm{~A}\right)$. Different to the $\mathrm{hH}_{3} \mathrm{R}$, the $\mathrm{pEC}_{50}$ value was unaltered by the blockage of the $\mathrm{G} \alpha_{\mathrm{q} / 11}$ protein with $\mathrm{FR}$ (Figure 6B).

2.3.2. Impact of the G $\beta \gamma$ Protein Modulator Gallein on the DMR Response upon Stimulation with Histamine

In addition to $G \alpha$, the $G \beta \gamma$ dimer is also able to interact with effectors in the signal transduction process. A contribution of $G \beta \gamma$ to the DMR response was assessed by means

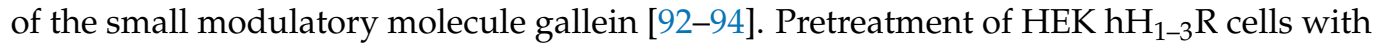


$20 \mu \mathrm{M}$ gallein prior to stimulation with HIS led only to a marginal reduction of the $\mathrm{E}_{\max }$ value to approximately 85\% compared to control cells (Figure 5B, red traces and Figure 6A). In the case of the $\mathrm{hH}_{4} \mathrm{R}$, the same gallein concentration significantly reduced the $\mathrm{E}_{\max }$ value to $71 \pm 9.3 \%$. The $\mathrm{pEC}_{50}$ value for HIS remained unaltered by the treatment with gallein (Figure 6B). The modulatory effect of gallein on $\mathrm{E}_{\max }$ values was markedly weaker at $\mathrm{hH}_{1-4}$ Rs than for individual $\mathrm{G} \alpha$ modulators $(1.00 \mu \mathrm{M} \mathrm{FR}, 100 \mathrm{ng} / \mathrm{mL}$ CTX and $100 \mathrm{ng} / \mathrm{mL}$ PTX). This may indicate that the endogenous $G \beta \gamma$ subunit plays a minor role in $\mathrm{hH}_{1-4} \mathrm{Rs}$ signal transduction in the DMR assay. Previous investigations using the cAMP-sensitive luciferase reporter gene assay with $\mathrm{hH}_{1,2} \mathrm{Rs}$ stably expressed in HEK293T cells also showed gallein as ineffective at reducing signal response $\left(\mathrm{hH}_{1} \mathrm{R}\right.$ [20] or $\mathrm{hH}_{2} \mathrm{R}$ [97]). Unfortunately, to the best of our knowledge, comparable investigations with gallein concerning $\mathrm{hH}_{3,4} \mathrm{Rs}$ expressed in HEK cells were not available. Lavenus et al. [45] came to a similar conclusion when investigating the effect of $20 \mu \mathrm{M}$ gallein on the Angiotensin II-induced response in HEK293-AT 1 R cells using the label-free surface plasmon resonance (SPR) technique. Further experiments are therefore necessary to clarify the involvement of $G \beta \gamma$ dimer in the signal transduction mediated by the $\mathrm{hH}_{1-4} \mathrm{Rs}$.

\subsubsection{Impact of $\mathrm{G} \alpha$ Protein Modulator Combinations on the Histamine Induced DMR Response}

None of the four HR subtypes displayed completely suppressed DMR signals with single $\mathrm{G}$ protein modulators (Figure 6A). These results prompted us to investigate whether a complete inhibition of the DMR signal in $\mathrm{HEK} \mathrm{H}_{1-4} \mathrm{R}$ cells is achievable by combining the G $\alpha$ protein modulators PTX, CTX and FR. At this point it should be noted that PTX and CTX were used at a concentration of $10.0 \mathrm{ng} / \mathrm{mL}$ instead of $100 \mathrm{ng} / \mathrm{mL}$ to avoid off target effects, which was usually sufficient to achieve the maximum effect (Supplementary Figure $\mathrm{S11}$ ). $\mathrm{HEK} \mathrm{hH}_{1-4} \mathrm{R}$ cells were treated with indicated modulators prior to stimulation with $10 \mu \mathrm{M}$ HIS (Figure 7).

In $\mathrm{HEK} \mathrm{hH}_{1} \mathrm{R}$ cells, each of the modulator combinations changed the time course of the HIS induced DMR response (Figure 7A), consistent with results from experiments with individual modulators (Figure $5 \mathrm{~B}$ ). Substantial depression of $\mathrm{E}_{\max }$ to $14 \pm 8.4 \%$ was seen in HEK $\mathrm{hH}_{1} \mathrm{R}$ cells after pretreatment with a combination of PTX and CTX (Figure 7B), corroborating with our previous results for the individual contributions of $G \alpha_{\mathrm{s} / \mathrm{i} / \mathrm{o}}$. A stronger reduction of the signal was observed when combining either PTX or CTX with $\mathrm{FR}$, where the signal was reduced almost to the basal level $\left(\mathrm{E}_{\max }(\mathrm{PTX}+\mathrm{FR})=3.4 \pm 3.5 \%\right.$, $\mathrm{E}_{\max }(\mathrm{CTX}+\mathrm{FR})=5.7 \pm 0.8 \%$; Figure $\left.7 \mathrm{~B}\right)$. The DMR signal was completely removed with a combination of the three modulators (PTX, CTX and FR). Therefore, we hypothesize that

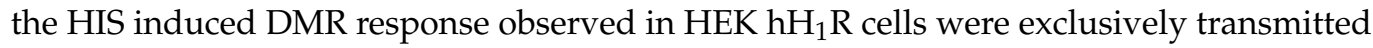
via the three main classes of $G$ proteins, namely $G \alpha_{q / 11}, G \alpha_{s}$ and $G \alpha_{i / o}$ proteins.

In accordance with the observations on individually applied $\mathrm{G} \alpha$ protein modulators (Figure 6), none of the modulator combinations altered the time course of the DMR response in $\mathrm{HEK} \mathrm{hH}_{2} \mathrm{R}$ cells (Figure 7A). Surprisingly, the HIS induced DMR response in $\mathrm{HEK} \mathrm{hH}_{2} \mathrm{R}$ cells was not even reduced by half upon treatment with a triple modulator combination $\left(\mathrm{E}_{\max }(\mathrm{CTX}, \mathrm{PTX}, \mathrm{FR})=55 \pm 2.2 \%\right)$. In supplementary Figure S11, we showed that for both PTX and CTX, increasing the concentration from $10 \mathrm{ng} / \mathrm{mL}$ to $100 \mathrm{ng} / \mathrm{mL}$ no longer significantly reduced the DMR signal at the $\mathrm{hH}_{2} \mathrm{R}$ and $\mathrm{FR}$ had no effect on the $\mathrm{E}_{\max }$ value at $\mathrm{hH}_{2} \mathrm{R}$. Thus, we can exclude that PTX and CTX at a concentration of $10 \mathrm{ng} / \mathrm{mL}$ might not have been sufficient to completely inhibit the respective signaling pathways. Beyond this, at the $\mathrm{hH}_{1,3,4} \mathrm{Rs}$, the same modulator combination caused a more pronounced decrease in the $E_{\max }$ value (Figure 7). Both arguments suggest that the weak impact of the triple modulator combination on the $\mathrm{E}_{\max }$ was a $\mathrm{hH}_{2} \mathrm{R}$-specific phenomenon. We conclude that in $\mathrm{HEK} h \mathrm{H}_{2} \mathrm{R}$ cells the $\mathrm{G} \alpha_{\mathrm{q} / 11}, \mathrm{G} \alpha_{\mathrm{s}}$ and $\mathrm{G} \alpha_{\mathrm{i} / \mathrm{o}}$ are not mainly responsible for the HIS induced DMR response, opposed to the $\mathrm{hH}_{1,3,4}$ Rs. Referring to the aforementioned hypotheses constructed from the individually applied modulators, it appears that the $\mathrm{hH}_{2} \mathrm{R}$ is not only promiscuous with these $\mathrm{G} \alpha$ proteins, but there is also growing evidence for a possible 
interaction of $\mathrm{hH}_{2} \mathrm{R}$ with the $\mathrm{G} \alpha_{12 / 13}$ and/or $\mathrm{G} \alpha_{\mathrm{z}}$, which are endogenously expressed in HEK cells [62].

A
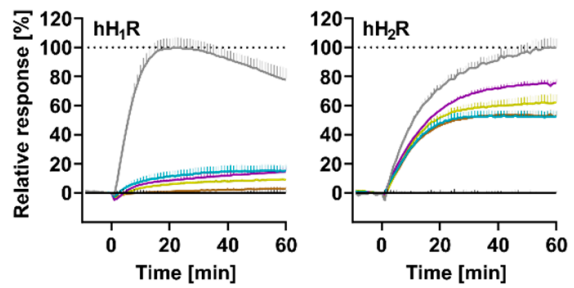

B
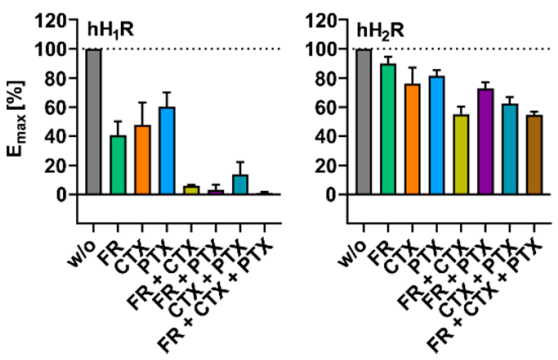
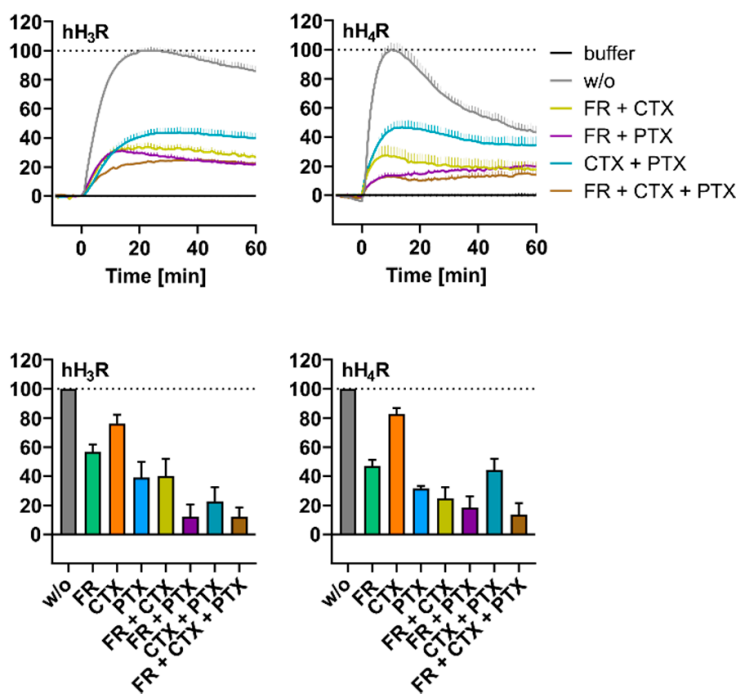

Figure 7. Impact of a combined application of $\mathrm{G} \alpha$ protein modulators FR, CTX and PTX on the DMR response at $\mathrm{hH}_{1-4} \mathrm{R}$. (A) Representative DMR traces recorded for HIS in the absence (w/o) and in the presence of $\mathrm{G} \alpha$ protein modulators FR $(1 \mu \mathrm{M}, 30 \mathrm{~min}$ before measurement), CTX and/or PTX (both $10 \mathrm{ng} / \mathrm{mL}$ overnight) in $\mathrm{HEK} \mathrm{hH}_{1-4} \mathrm{R}$ cells. (B) The $\mathrm{AUC}_{60}$ was calculated for the traces and normalized to the $\mathrm{AUC}_{60}$ of the untreated control $(10 \mu \mathrm{M}$ HIS without (w/o) modulator (100\%) and to the $\mathrm{AUC}_{60}$ of the buffer control $(0 \%)$. The values represent mean \pm SEM of three independent experiments each performed in triplicate.

In experiments with individually applied $\mathrm{G} \alpha$ modulators, a marked deceleration of the DMR response was observed in $\mathrm{HEK} \mathrm{hH}_{3} \mathrm{R}$ cells in the presence of $10 \mathrm{ng} / \mathrm{mL}$ PTX (Figure 5B). As expected, such a retardation of the DMR signal was observed when HEK $\mathrm{hH}_{3} \mathrm{R}$ cells were pre-treated with modulator combinations comprising $10 \mathrm{ng} / \mathrm{mL}$ of PTX (Figure 7A). Unexpectedly, a combination of $1 \mu \mathrm{M} F R+10 \mathrm{ng} / \mathrm{mL}$ of CTX decelerated the DMR response. Moreover, the same combination (FR $+\mathrm{CTX}$ ) markedly reduced the $\mathrm{E}_{\max }$ to $40 \pm 12 \%$ (Figure $7 \mathrm{~B}$ ). Both the impact on the time courses and the reduced $E_{\max }$ value in the presence of FR + CTX suggest that $G \alpha_{\mathrm{q} / 11}$ and $G \alpha_{\mathrm{s}}$ are involved in the $\mathrm{hH}_{3} \mathrm{R}$ mediated DMR response. However, in comparison, a stronger decrease in $\mathrm{E}_{\max }$ value was observed when combining $1 \mu \mathrm{M}$ FR with $10 \mathrm{ng} / \mathrm{mL}$ of PTX to jointly inhibit $\mathrm{G} \alpha_{\mathrm{q} / 11}$ and $\mathrm{G} \alpha_{\mathrm{i} / \mathrm{o}}$ signaling pathways. This modulator combination reduced the $\mathrm{E}_{\max }$ to $12 \pm 8.3 \%$, reaching a plateau that was found to be non-suppressible by the triple modulator combination of $\mathrm{FR}+\mathrm{CTX}+\mathrm{PTX}\left(\mathrm{E}_{\max }=12 \pm 6.4 \%\right.$; Figure 7B) suggesting that $\mathrm{G} \alpha_{\mathrm{i} / \mathrm{o}}$ and $\mathrm{G} \alpha_{\mathrm{q} / 11}$ played a more pronounced role in the $\mathrm{hH}_{3} \mathrm{R}$ mediated DMR response to HIS than $\mathrm{G} \alpha_{\mathrm{s}}$. Again, as with the $\mathrm{hH}_{2} \mathrm{R}$, the HIS induced DMR response was not completely ablated by the triple modulator combination. Inter alia, one possible explanation for this might be an involvement of additional $G$ proteins such as $G \alpha_{12 / 13}$ and /or $G \alpha_{z}$. However, it should be noted that, unlike for the $\mathrm{hH}_{1,2} \mathrm{Rs}$, the concentration of CTX in the triple modulator combination (FR + CTX + PTX) is a factor to be considered. In experiments with CTX alone (Supplementary Figure S11), $10 \mathrm{ng} / \mathrm{mL}$ CTX were not sufficient to achieve the maximum effect. Precisely, in the presence of $10 \mathrm{ng} / \mathrm{mL}$ an $\mathrm{E}_{\max }$ value of $76 \pm 6.3 \%$ was obtained, whereas $100 \mathrm{ng} / \mathrm{mL}$ CTX reduced the $\mathrm{E}_{\max }$ value to $54 \pm 7.6 \%$. Although this difference was not determined to be significant (one-way ANOVA analysis followed by Tukey's multiple comparison test; $p=0.1980$ ), we still find it worth mentioning.

Likewise, we examined the influence of modulator combinations on the DMR signal in $\mathrm{HEK} \mathrm{hH}_{4} \mathrm{R}$ cells. We would like to note that the differences in $\mathrm{E}_{\max }$ values between the 
different modulator combinations were subtly nuanced rather than clear, just as with the individual modulators in Section 2.3.1. None of the $G \alpha$ modulators effected the time courses of the HIS induced DMR responses when applied individually (Figure 5B). However, in combination, FR + PTX and FR + CTX + PTX altered the time course of the DMR response to HIS (Figure 7A). In both cases the DMR signal showed no peak and did not decline continuously, as observed in control experiments without modulators (Figure 2A). Instead, the DMR response increased steadily over time upon stimulation with HIS (Figure 7A). We took this as a hint that $G \alpha_{\mathrm{q} / 11}$ and $\mathrm{G} \alpha_{\mathrm{i} / \mathrm{o}}$ have more impact on the signal transduction of $\mathrm{hH}_{4} \mathrm{R}$ in HEK cells than $\mathrm{G} \alpha_{s}$; nevertheless, the involvement of the latter should not be neglected. This opinion was enforced when $\mathrm{E}_{\max }$ values were considered (Figure $7 \mathrm{~B}$ ); the treatment of $\mathrm{HEK} \mathrm{hH}_{4} \mathrm{R}$ cells with CTX + PTX decreased the $\mathrm{E}_{\max }$ to $44 \pm 7.7 \%$, whereas addition of FR (FR + CTX + PTX) reduced the $E_{\max }$ to a final value of $14 \pm 8.0 \%$, relative to control cells. It is also remarkable that a jointly inhibition of $\mathrm{G} \alpha_{\mathrm{q} / 11}$ and $\mathrm{G} \alpha_{\mathrm{i} / \mathrm{o}}$ signaling pathways with FR + PTX decreased the maximum response by almost the same level $\left(\mathrm{E}_{\max }=19 \pm 7.7 \%\right)$ as the triple combination FR + CTX + PTX. Unexpectedly, the $\mathrm{E}_{\max }$ value in presence of $10 \mathrm{ng} / \mathrm{mL} \mathrm{CTX}+10 \mathrm{ng} / \mathrm{mL}$ PTX was higher $\left(\mathrm{E}_{\max }=44 \pm 7.7 \%\right)$ than that upon treatment with $10 \mathrm{ng} / \mathrm{mL}$ of PTX alone ( $\left.E_{\max }=32 \pm 1.9 \%\right)$. This might be due to the mechanism of action of CTX, as CTX does not directly inhibit the $\mathrm{G} \alpha_{\mathrm{s}}$ protein, but rather masks the $G \alpha_{s}$ dependent signaling pathway by permanent $G \alpha_{s}$ protein activation. Similar to the $\mathrm{hH}_{3} \mathrm{R}$, the inhibition of the three signaling pathways was not sufficient to completely remove the $\mathrm{hH}_{4} \mathrm{R}$ mediated response, as $14 \pm 8.0 \%$ of $\mathrm{E}_{\max }$ remained after treatment with FR + CTX + PTX (Figure 7B). Again, as with the $\mathrm{hH}_{3} \mathrm{R}$, this demonstrates that signal transduction of the $\mathrm{hH}_{4} \mathrm{R}$ overexpressed in HEK cells occurred mainly through activation of $G \alpha_{i / o}, G \alpha_{s}$ and $G \alpha_{q / 11}$ proteins, but the DMR signal might also arise from either $G \beta \gamma, G \alpha_{12 / 13}$ and/or $G \alpha_{Z}$ proteins.

Of note, the two structurally related receptor subtypes $\mathrm{hH}_{3} \mathrm{R}$ and $\mathrm{hH}_{4} \mathrm{R}$ have similar coupling specificities to $\mathrm{G} \alpha$ proteins, and so it is unsurprising that so that inhibition of the corresponding $\mathrm{G} \alpha$ signaling pathways led to comparable reduction in $\mathrm{E}_{\max }$ values.

\subsection{Investigation of HIS Induced DMR Signaling in G Protein Knock Out Cells}

2.4.1. Expression of $\mathrm{hH}_{1-4} \mathrm{Rs}$ in $\Delta \mathrm{G} \alpha_{\mathrm{s}}$ HEK Cells

In addition to the concept of classical pharmacology, namely the employment of specific $G$ protein modulators as molecular tools to elucidate cellular processes, we explored a molecular biology approach to better understand the contribution of individual $G \alpha$ isoforms to the $\mathrm{hH}_{1-4} \mathrm{R}$ mediated DMR response using CRISPR/Cas9 modified HEK cells devoid of distinct $\mathrm{G} \alpha$ proteins ( $\Delta \mathrm{G} \alpha_{\mathrm{x}}$ HEK cells). For the generation of $\Delta \mathrm{G} \alpha_{\mathrm{x}} \mathrm{HEK} \mathrm{hH}_{1-4} \mathrm{R}$ cells the $\Delta \mathrm{G} \alpha_{\mathrm{s} / 1}$ HEK [63], $\Delta \mathrm{G} \alpha_{\mathrm{q} / 11}$ HEK [44], $\Delta \mathrm{G} \alpha_{12 / 13}$ HEK [64] and $\Delta \mathrm{G} \alpha_{\text {six }}$ HEK [41] cells were stably transfected with the pIRESneo3-SP-FLAG-hH ${ }_{1-4} \mathrm{R}$ constructs and used as polyclonal cell lines. We confirmed the expression of the $\mathrm{hH}_{1-4} \mathrm{Rs}$ in $\Delta \mathrm{G} \alpha_{\mathrm{x}} \mathrm{HEK} \mathrm{hH}_{1-4} \mathrm{R}$ cells by radioligand saturation binding using live cells (Supplementary Figure S3). The

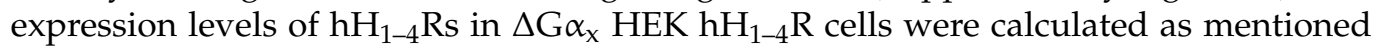
for $\mathrm{HEK} \mathrm{hH}_{1-4} \mathrm{R}$ cells (Table 1). When comparing the expression levels of respective HR

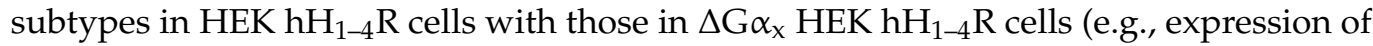

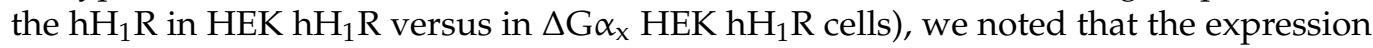
levels of $\mathrm{hH}_{2-4} \mathrm{Rs}$ were in the same range. In the case of the $\mathrm{hH}_{1} \mathrm{R}$, the expression level

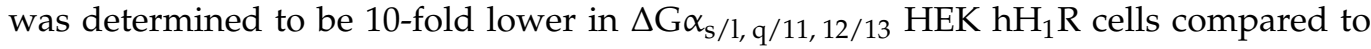
$\mathrm{HEK} \mathrm{hH}_{1} \mathrm{R}$ cells. On the one hand, this difference may be due to the single clone selection procedure by which only the highest response $\mathrm{HEK}_{\mathrm{hH}} \mathrm{R}$ cells were obtained, thereby having the highest receptor expression level. The fact that only the binding capacity but not the affinity of the radioligand $\left[{ }^{3} \mathrm{H}\right] \mathrm{MEP}$ was affected would argue in favor of this. However, this is contradicted by the fact that no difference in expression level

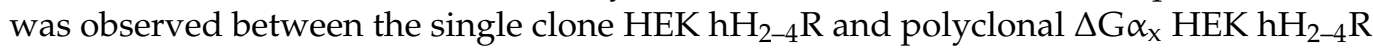
cells. On the other hand, we cannot exclude that knock-out of $\mathrm{G} \alpha$ proteins might have impaired either the expression of the $\mathrm{hH}_{1} \mathrm{R}$ or the detection of the binding capacity of 
the radioligand $\left[{ }^{3} \mathrm{H}\right] \mathrm{MEP}$ to the $\mathrm{hH} \mathrm{H}_{1} \mathrm{R}$ in $\Delta \mathrm{G} \alpha_{\mathrm{x}}$ HEK $\mathrm{hH} \mathrm{H}_{1} \mathrm{R}$ cells. This suspicion arose when we failed to detect the expression of the $\mathrm{hH}_{1} \mathrm{R}$ in $\Delta \mathrm{G} \alpha_{\text {six }} \mathrm{hH}_{1} \mathrm{R}$ cells by radioligand saturation binding (Supplementary Figure S3), although a concentration-dependent signal was detected in the DMR assay when these cells were stimulated with HIS (Section 2.4.2 and supplementary Figure S12). By contrast, no DMR signal was observed in $\Delta G \alpha_{\text {six }}$ HEK cells devoid of the $\mathrm{hH}_{1} \mathrm{R}$ (Supplementary Figure S6), suggesting that the $\mathrm{hH}_{1} \mathrm{R}$ was expressed in $\Delta \mathrm{G} \alpha_{\text {six }} \mathrm{HEK}_{\mathrm{hH}} \mathrm{R}$ cells. For MEP, which has been reclassified as an inverse agonist [98], multiple binding sites differing in affinity and binding capacity for the $\mathrm{H}_{1} \mathrm{R}$ have been reported $[99,100]$. Moreover, the intrinsic negative efficacy of MEP is thought to be due to the stabilization of a G-protein-coupled state of the $\mathrm{H}_{1} \mathrm{R}$ that is not capable of eliciting a response [100]. Considering this, we argue in favor of the latter hypothesis, namely that the absence of $\mathrm{G} \alpha$ proteins may have affected the binding of $\left[{ }^{3} \mathrm{H}\right] \mathrm{MEP}$ to the $\mathrm{hH}_{1} \mathrm{R}$. However, as this research project is focused on the results in the DMR assay, we have not pursued this issue. The $\mathrm{pK}_{d}$ values determined with both $H E K \mathrm{hH}_{1-4} \mathrm{R}$ and $\Delta \mathrm{G} \alpha_{\mathrm{x}}$ HEK $\mathrm{hH}_{1-4} \mathrm{R}$ cells were in very good agreement with literature data (Table 1 ), except for $\Delta \mathrm{G} \alpha_{12 / 13} \mathrm{hH}_{2} \mathrm{R}$ and $\Delta \mathrm{G} \alpha_{\text {six }} \mathrm{hH}_{2} \mathrm{R}$. In both cases, the $\mathrm{pK}_{\mathrm{d}}$ value increased significantly to $7.98+0.05\left(\Delta \mathrm{G} \alpha_{12 / 13} \mathrm{hH}_{2} \mathrm{R}, p<0.0001\right)$ and $7.86+0.06\left(\Delta \mathrm{G} \alpha_{\text {six }} \mathrm{hH}_{2} \mathrm{R}, p=0.0004\right)$ relative to the value determined using $\mathrm{HEK} \mathrm{hH}_{2} \mathrm{R}$ cells $\left(\mathrm{pK}_{\mathrm{d}}=7.19+0.06\right)$. Apparently, the absence of $\mathrm{G} \alpha_{12 / 13}$ facilitates the binding of the radioligand $\left[{ }^{3} \mathrm{H}\right] \mathrm{DE}-257$ to the $\mathrm{hH}_{2} \mathrm{R}$.

The impact of $\mathrm{G} \alpha$ protein knock-out on the affinity of $\mathrm{HIS}$ to the $\mathrm{hH}_{1-4} \mathrm{Rs}$ was analyzed by radioligand competition binding with $\mathrm{HIS}$ as a competitor using live $\Delta \mathrm{G} \alpha_{\mathrm{x}} \mathrm{HEK} \mathrm{hH}_{1-4} \mathrm{R}$ cells (Figure 8 and supplementary Table S2). Of note, such experiments were not performed with $\Delta \mathrm{G} \alpha_{\text {six }} \mathrm{HEK} \mathrm{hH}_{1} \mathrm{R}$, as the expression of $\mathrm{hH}_{1} \mathrm{R}$ was not detectable in saturation binding experiments. Unfortunately, in $\Delta \mathrm{G} \alpha_{\mathrm{s} / 1, \mathrm{q} / 11} \mathrm{HEK} \mathrm{hH}_{1} \mathrm{R}$ cells a $\mathrm{pK} \mathrm{K}_{\mathrm{i}}$ value could not be determined for HIS due to an ambiguous curve fit of the data. Although not statistically significant ( $p=0.0545$, $t$-test two-tailed), the $\mathrm{pK}_{\mathrm{i}}$ value for $\mathrm{HIS}$ in $\Delta \mathrm{G} \alpha_{12 / 13} \mathrm{HEK} \mathrm{hH}_{1} \mathrm{R}$ cells $\left(\mathrm{pK}_{\mathrm{i}}=2.23 \pm 0.37\right)$ was approx. one order of magnitude lower than at $\mathrm{HEK}_{\mathrm{hH}} \mathrm{R}$ cells $\left(\mathrm{pK}_{\mathrm{i}}=3.37 \pm 0.29\right)$. While the absence of $\mathrm{G} \alpha_{\mathrm{s} / 1}$ or $\mathrm{G} \alpha_{\mathrm{q} / 11}$ proteins in $\Delta \mathrm{G} \alpha_{\mathrm{s} / 1, \mathrm{q} / 11}$ HEK $\mathrm{hH}_{2} \mathrm{R}$ cells had no impact on the $\mathrm{pK}_{\mathrm{i}}$ of HIS $\left(\mathrm{pK}_{\mathrm{i}}=3.68 \pm 0.09\right.$ and $4.23 \pm 0.11$, respec-

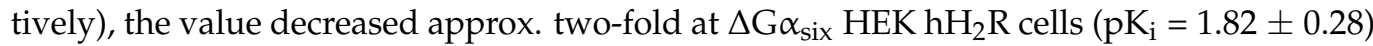
compared to HEK $\mathrm{hH}_{2} \mathrm{R}$ cells $\left(\mathrm{pK}_{\mathrm{i}}=4.32 \pm 0.38\right)$. The listed discrepancy of the $\mathrm{pK}_{\mathrm{i}}$ values of $\mathrm{HIS}$ at the $\mathrm{hH}_{1,2} \mathrm{Rs}$ were not surprising, as saturation binding experiments (Table 1) demonstrate that the absence of $\mathrm{G} \alpha$ proteins can positively or negatively impact ligand binding at the $\mathrm{hH}_{1,2} \mathrm{Rs}$. The $\mathrm{pK}_{\mathrm{i}}$ values determined for HIS using $\Delta \mathrm{G} \alpha_{\mathrm{x}} \mathrm{HEK} \mathrm{hH}_{3,4} \mathrm{R}$ cells were in good agreement with literature data and the results determined with $\mathrm{HEK}_{\mathrm{hH}} \mathrm{H}_{3,4} \mathrm{R}$ cells (Supplementary Table S2).

\subsubsection{Stimulation of $\Delta \mathrm{G} \alpha_{\mathrm{x}} \mathrm{HEK} \mathrm{hH}_{1-4} \mathrm{R}$ Cells in the DMR Assay with HIS}

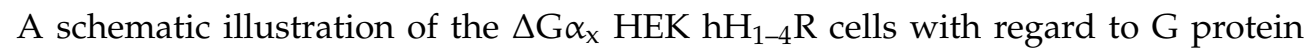
knock-out is given in Figure 9A. The $\Delta \mathrm{G} \alpha_{x} \mathrm{HEK} \mathrm{hH}_{1-4} \mathrm{R}$ cells were stimulated with HIS at increasing concentrations and the DMR response was recorded for $60 \mathrm{~min}$. Throughout, the DMR traces showed a positive deflection and were concentration dependent (Figure 9B; $\mathrm{AUC}_{60}$ CRCs in supplementary Figure S12). By contrast, stimulation of $\Delta \mathrm{G} \alpha_{\mathrm{q} / 11} \mathrm{HEK}$, $\Delta \mathrm{G} \alpha_{12 / 13} \mathrm{HEK}$ and $\Delta \mathrm{G} \alpha_{\text {six }}$ HEK cells devoid of $\mathrm{hH}_{1-4}$ Rs with HIS did not provoke a DMR signal. However, with $\Delta \mathrm{G} \alpha_{\mathrm{S}}$ HEK cells, devoid of a HR subtype, a slight increase in the DMR signal was observed, but only at high HIS concentrations (1.00 and $10.0 \mu \mathrm{M})$. Therefore, we considered this DMR increase as negligible due to its low intensity (Supplementary Figure S6). To evaluate the effect of $\mathrm{G} \alpha$ protein knock-out on the DMR response, the $\mathrm{AUC}_{60}$ at the respective HIS concentration $\left(\mathrm{hH}_{1,2,4} \mathrm{Rs} 10 \mu \mathrm{M}\right.$ HIS and $\mathrm{hH}_{3} \mathrm{R} 100 \mu \mathrm{M}$ HIS) using $\Delta \mathrm{G} \alpha_{\mathrm{x}} \mathrm{HEK} h \mathrm{H}_{1-4} \mathrm{R}$ cells was compared to the mean $\mathrm{AUC}_{60}$ of $\mathrm{HEK} h \mathrm{H}_{1-4} \mathrm{R}$ cells, in which all $\mathrm{G}$ proteins were present (100\% control, Figure 10). This approximation was reasonable, because mostly the expression of the different receptor subtypes was comparable (Table 1). 

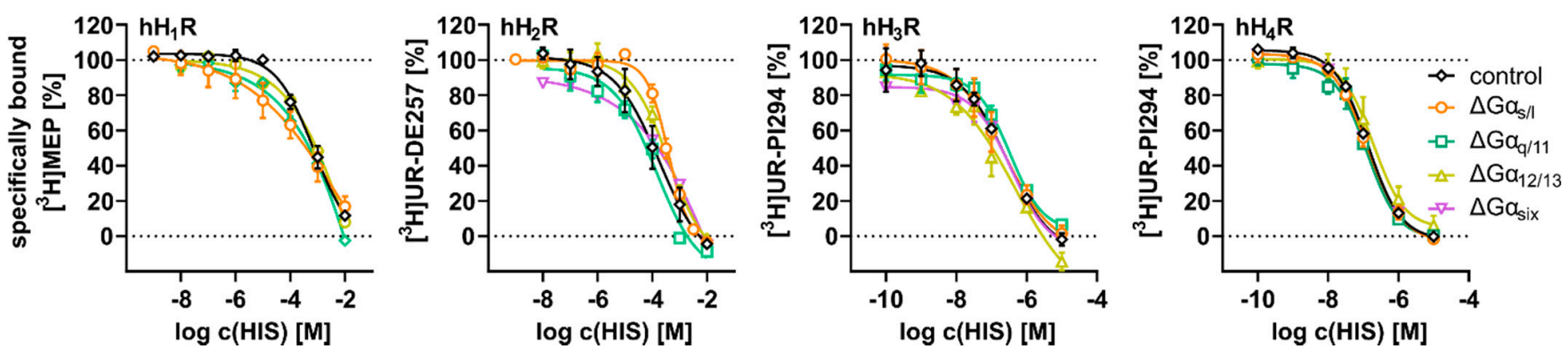

Figure 8. Radioligand displacement curves determined for histamine (HIS) at $\mathrm{HEK} \mathrm{hH}_{1-4} \mathrm{R}$ and $\Delta \mathrm{G} \alpha_{\mathrm{x}} \mathrm{hH} \mathrm{H}_{1-4} \mathrm{R}$ cells. HIS was incubated at indicated concentrations in the presence of $5 \mathrm{nM}\left[{ }^{3} \mathrm{H}\right]$ mepyramine $\left(\left[{ }^{3} \mathrm{H}\right] \mathrm{MEP}\right)$ at the $\mathrm{hH} \mathrm{H}_{1} \mathrm{R}, 50 \mathrm{nM}$ $\left[{ }^{3} \mathrm{H}\right] \mathrm{UR}$-DE257 at the $\mathrm{hH}_{2} \mathrm{R}, 2 \mathrm{nM}$ or $5 \mathrm{nM}\left[{ }^{3} \mathrm{H}\right] \mathrm{UR}-\mathrm{PI} 294 \mathrm{hH}_{3} \mathrm{R}$ or $\mathrm{hH}_{4} \mathrm{R}$, respectively. The non_specific binding was determined in the presence of DPH $\left(\mathrm{hH}_{1} \mathrm{R}\right)$, FAM $\left(\mathrm{hH}_{2} \mathrm{R}\right)$ or HIS $\left(\mathrm{hH}_{3,4} \mathrm{Rs}\right)$, each at a final concentration of $10 \mu \mathrm{M}$. The non-specific binding was subtracted from the total binding to receive the specific binding. Specific binding was normalized to the buffer value $(100 \%)$ and the corrected non_specific binding value $(0 \%)$. Each point represents mean \pm SEM of at least three independent experiments, each performed in triplicate.

When comparing the HIS induced DMR responses of $\Delta \mathrm{G} \alpha_{\mathrm{s} / 1,12 / 13} \mathrm{HEK} \mathrm{hH}_{1} \mathrm{R}$ with that of $\mathrm{HEK} \mathrm{hH}_{1} \mathrm{R}$ cells by visual inspection, there was no discernible difference (Figure $9 \mathrm{~B}$ ). Consequently, the $\mathrm{E}_{\max }$ values for HIS using $\Delta \mathrm{G} \alpha_{\mathrm{s} / 1,12 / 13} \mathrm{HEK} \mathrm{hH}_{1} \mathrm{R}$ were not significantly different from the control cell line $\mathrm{HEK}_{\mathrm{hH}} \mathrm{R}$ (Figure 10A). Of note, in Section 2.4.1 we discussed that the binding capacity of $\left[{ }^{3} \mathrm{H}\right] \mathrm{MEP}$ was by factor 10 lower in $\Delta \mathrm{G} \alpha_{\mathrm{x}}$ HEK $\mathrm{hH}_{1} \mathrm{R}$ cells than in HEK $\mathrm{hH}_{1} \mathrm{R}$ cells. Apparently, this difference had no impact on the signal amplitude and the $\mathrm{E}_{\max }$ value, supporting the hypothesis that the absence of the $\mathrm{G} \alpha$ proteins impaired the binding of $\left[{ }^{3} \mathrm{H}\right] \mathrm{MEP}$ to the $\mathrm{hH}_{1} \mathrm{R}[99,100]$. The absence of the $\mathrm{G} \alpha_{\mathrm{s}}$ protein in $\Delta \mathrm{G} \alpha_{\mathrm{s} / 1} \mathrm{HEK} \mathrm{hH}_{1} \mathrm{R}$ cells caused the $\mathrm{pEC}_{50}$ value for HIS to significantly increase to $7.96+0.09$ compared to $\mathrm{HEK} \mathrm{hH}_{1} \mathrm{R}$ cells $\left(\mathrm{pEC}_{50}=7.43+0.05\right)$, an effect also observed in $\Delta \mathrm{G} \alpha_{12 / 13} \mathrm{HEK}_{\mathrm{hH}} \mathrm{R}$ cells $\left(\mathrm{pEC}_{50}=7.78+0.05\right)$. By contrast, the absence of the $\mathrm{G} \alpha_{\mathrm{q} / 11}$ protein in $\Delta \mathrm{G} \alpha_{\mathrm{q} / 11 \text {, six }} \mathrm{HEK} h \mathrm{hH}_{1} \mathrm{R}$ cells lowered the signal amplitude $\left(\mathrm{E}_{\max }=46 \pm 38 \%\right.$; Figure 10A) and slightly altered the time course of the signal (Figure 9B). Moreover, the $\mathrm{pEC}_{50}$ value for HIS in $\Delta \mathrm{G} \alpha_{\mathrm{q} / 11 \text {, six }} \mathrm{HEK} \mathrm{hH}_{1} \mathrm{R}$ cells was significantly lower in both cell

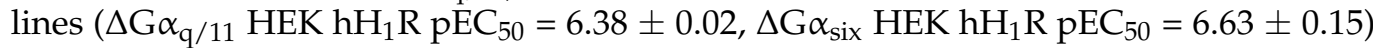
than with $\mathrm{HEK} \mathrm{hH}_{1} \mathrm{R}$ cells (Figure 10B). We still hypothesize that the presence of $\mathrm{G} \alpha_{\mathrm{q} / 11}$ stabilized the active state of $\mathrm{hH}_{1} \mathrm{R}$ in HEK cells and that this effect is further enhanced in the absence of other $\mathrm{G} \alpha$ proteins.

The lack of $\mathrm{G} \alpha$ proteins in $\Delta \mathrm{G} \alpha_{\mathrm{x}}$ HEK $\mathrm{hH}_{2} \mathrm{R}$ cells did not alter the time course of the DMR response (Figure 9B). Despite the lack of the $G \alpha_{s}$ protein in $\Delta G \alpha_{s} H E K h H_{2} R$ cells, stimulation with HIS evoked a robust DMR response, similar to that observed with $\mathrm{HEK} h \mathrm{H}_{2} \mathrm{R}$ cells. Consequently, the $\mathrm{E}_{\max }$ value of $\Delta \mathrm{G} \alpha_{\mathrm{s}} \mathrm{HEK} \mathrm{hH}_{2} \mathrm{R}$ cells was not significantly different compared to $\mathrm{HEK} \mathrm{hH}_{2} \mathrm{R}$ cells (Figure 10A). This was unexpected, as we observed a significant decrease in $E_{\max }$ in our experiments with CTX to mask $G \alpha_{s}$.

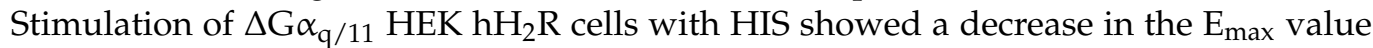
to $84 \pm 14 \%$ (Figure $10 \mathrm{~A}$ ) compared to $\mathrm{HEK}_{\mathrm{hH}} \mathrm{R}$ cells. The $\mathrm{pEC}_{50}$ value determined for HIS in $\Delta \mathrm{G} \alpha_{\mathrm{s} / 1, \mathrm{q} / 11} \mathrm{HEK} \mathrm{hH}_{2} \mathrm{R}$ cells remained in the same range as in $\mathrm{HEK}_{\mathrm{hH}} \mathrm{R}$ cells (Figure 10B). In Section 2.3.1 it was considered that $\mathrm{G} \alpha_{12 / 13}$ protein might be responsible for the HIS induced DMR at HEK $\mathrm{hH}_{2} \mathrm{R}$ cells. This hypothesis was affirmed as the signal

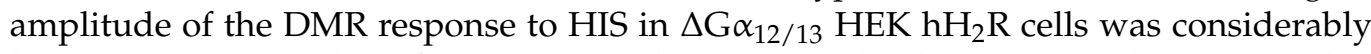
lower compared to that of $\mathrm{HEK} \mathrm{hH}_{2} \mathrm{R}$ cells (Figure $9 \mathrm{~B}$ ). The corresponding $\mathrm{E}_{\max }$ value determined in $\Delta \mathrm{G} \alpha_{12 / 13} \mathrm{HEK} \mathrm{hH}_{2} \mathrm{R}$ cells amounted to $10.0 \pm 0.8 \%$ (Figure 10A) relative to $\mathrm{HEK} h \mathrm{H}_{2} \mathrm{R}$ cells. In $\Delta \mathrm{G} \alpha_{\text {six }} \mathrm{HEK} \mathrm{hH}_{2} \mathrm{R}$ cells, which lack the $\mathrm{G} \alpha_{12 / 13}$ protein too, the $\mathrm{E}_{\max }$ value was also reduced significantly to $20 \pm 2.0 \%$. In addition to $\mathrm{E}_{\max }$, the $\mathrm{HIS}_{\mathrm{pEC}} \mathrm{C}_{50}$ value in both cell lines wassignificantly reduced $\left(\Delta \mathrm{G} \alpha_{12 / 13} \mathrm{HEK} \mathrm{hH}_{2} \mathrm{R} \mathrm{pEC} \mathrm{C}_{50}=5.77 \pm 0.46\right.$; $\Delta \mathrm{G} \alpha_{\text {six }}$ HEK $\left.\mathrm{hH}_{2} \mathrm{R} \mathrm{pEC}_{50}=6.01 \pm 0.04\right)$ compared to HEK $\mathrm{hH}_{2} \mathrm{R}$ cells $\left(\mathrm{pEC}_{50}=6.57 \pm 0.05\right.$; Figure 10B). We interpreted this as an indication that $\mathrm{G} \alpha_{12 / 13}$ might stabilize the active 
state of the $\mathrm{hH}_{2} \mathrm{R}$ and is essential for $\mathrm{hH}_{2} \mathrm{R}$ mediated signal transduction in HEK cells. Further studies are necessary to substantiate or rule out the involvement of other cellular constituents, such as $G \alpha_{z}$.

A

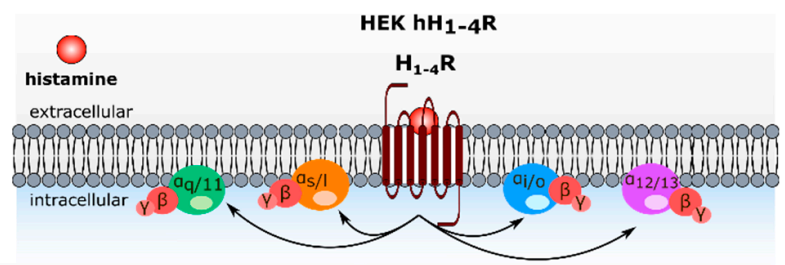

$\Delta \mathrm{Ga}_{\mathrm{s} / \mathrm{l}} \mathrm{HEK} \mathrm{hH} \mathrm{H}_{1-4} \mathrm{R}$

$\Delta G_{\mathrm{q} / 11} \mathrm{HEK} \mathrm{hH}_{1-4} R$

$\Delta \mathrm{Ga}_{12 / 13} \mathrm{HEK} \mathrm{hH}_{1-4} \mathrm{R}$

$\mathrm{H}_{1-4} \mathrm{R}$

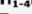

$\mathrm{H}_{1-4} \mathrm{R}$

$\Delta G_{\text {six }}{\text { HEK } h H_{1-4} R}^{H_{1-4} R}$

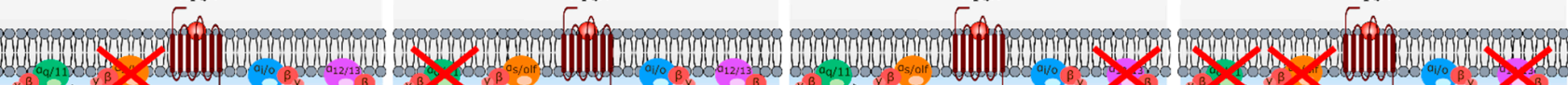

作

B

$\mathrm{hH}_{1} \mathrm{R}$
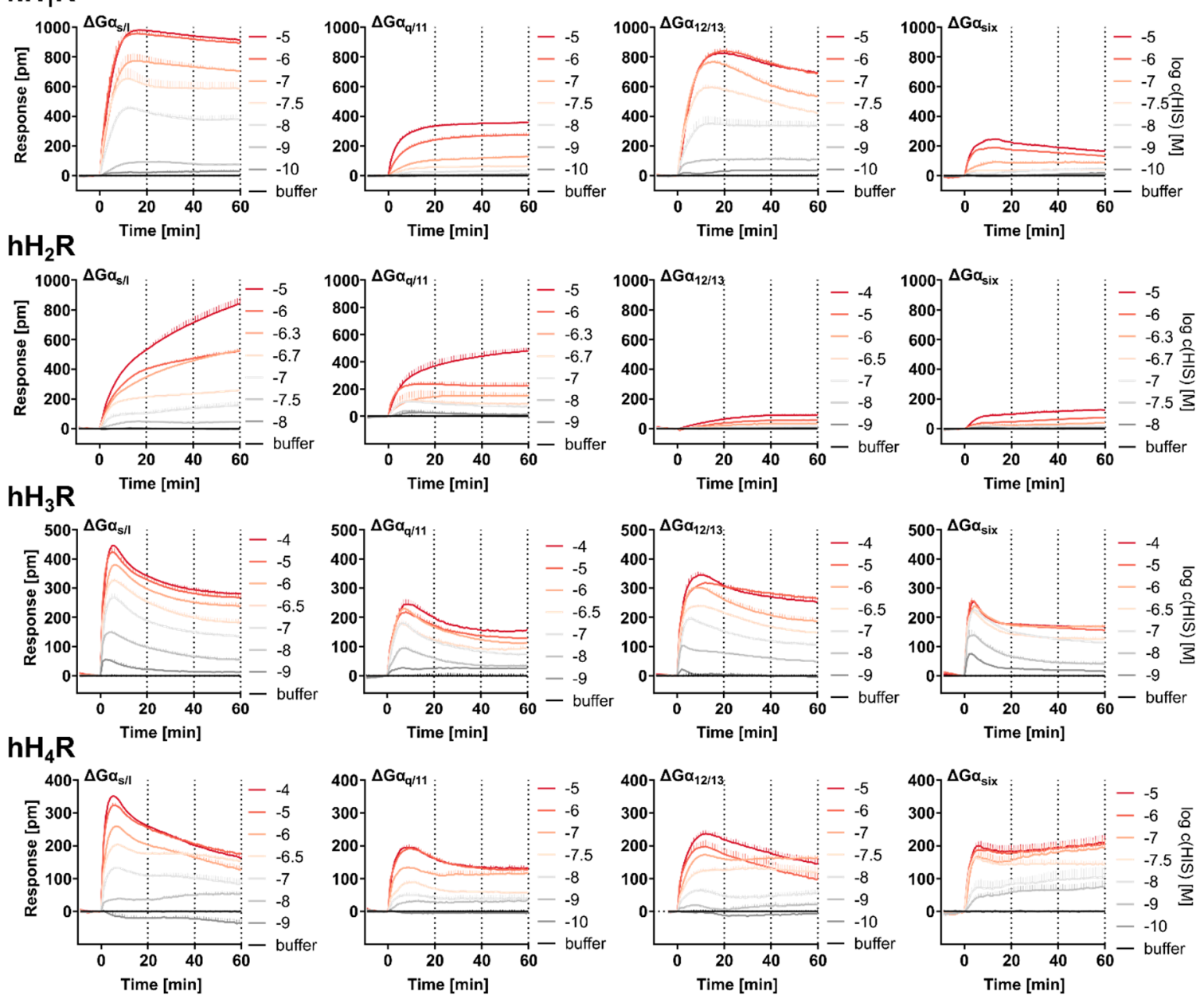

Figure 9. DMR responses recorded in $\mathrm{G} \alpha$ protein knock_out $\mathrm{HEK} \mathrm{hH}_{1-4} \mathrm{R}$ cells upon stimulation with HIS. (A) Schematics of used G $\alpha$ protein knock_out $\operatorname{HEK}\left(\Delta \mathrm{G} \alpha_{\mathrm{x}} \mathrm{HEK}\right)$ cells. The $\Delta \mathrm{G} \alpha_{\mathrm{x}}$ HEK cells lacking either the $\mathrm{G} \alpha_{\mathrm{s} / 1}\left(\Delta \mathrm{G} \alpha_{\mathrm{s} / 1} \mathrm{HEK}\right)$ [63], the $\mathrm{G} \alpha_{\mathrm{q} / 11}\left(\Delta \mathrm{G} \alpha_{\mathrm{q} / 11} \mathrm{HEK}\right)$ [44], the $\mathrm{G} \alpha_{12 / 13}\left(\Delta \mathrm{G} \alpha_{12 / 13} \mathrm{HEK}\right)$ [64] or six G $\alpha$ proteins $\left(\Delta \mathrm{G} \alpha_{\mathrm{s} / 1, \mathrm{q} / 11,12 / 13}=\Delta \mathrm{G} \alpha_{\text {six }} \mathrm{HEK}\right)$ [41] were stably transfected with $\mathrm{hH}_{1-4}$ Rs. The knocked_out $\mathrm{G} \alpha$ protein is marked with a red " $\mathrm{X}^{\prime}$. $\mathrm{HEK}_{\mathrm{hH}} \mathrm{H}_{1-4} \mathrm{R}$ cells,

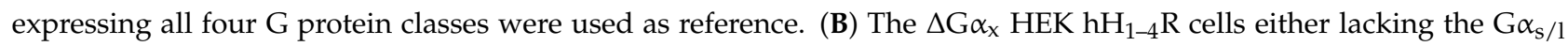
$\left(\Delta \mathrm{G} \alpha_{\mathrm{s} / 1}\right), \mathrm{G} \alpha_{\mathrm{q} / 11}\left(\Delta \mathrm{G} \alpha_{\mathrm{q} / 11}\right), \mathrm{G} \alpha_{12 / 13}\left(\Delta \mathrm{G} \alpha_{12 / 13}\right)$ or $\mathrm{G} \alpha_{\mathrm{s} / 1}, \mathrm{q} / 11,12 / 13\left(\Delta \mathrm{G} \alpha_{\text {six }}\right)$ proteins were stimulated with indicated HIS concentration and the DMR response was recorded for $60 \mathrm{~min}$. Depicted are representative DMR traces, which were corrected for the buffer. Each trace represent mean \pm SEM of a representative experiment performed in triplicate. 
A

$\mathrm{hH}_{1} \mathrm{R}$

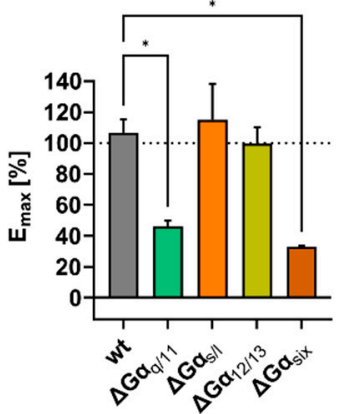

B

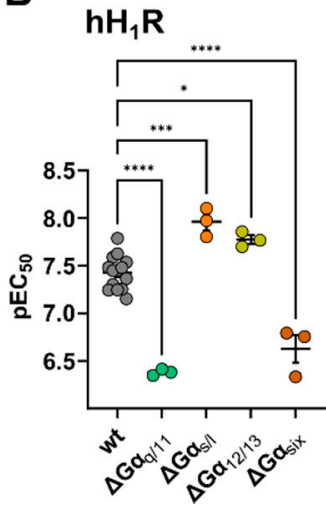

$\mathrm{hH}_{2} \mathrm{R}$

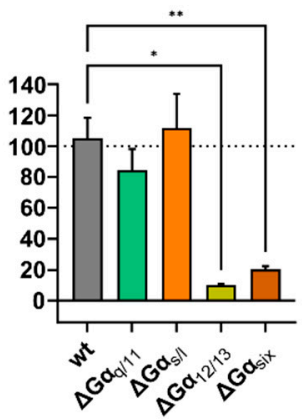

$\mathrm{hH}_{2} \mathrm{R}$

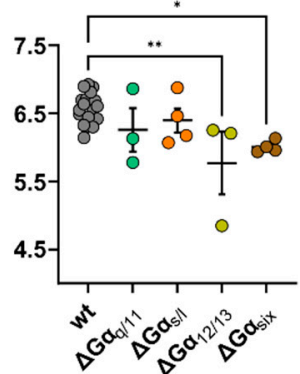

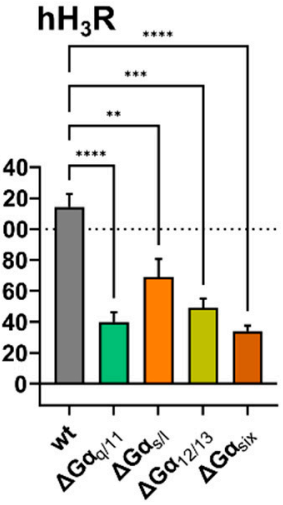

$\mathrm{hH}_{3} \mathrm{R}$

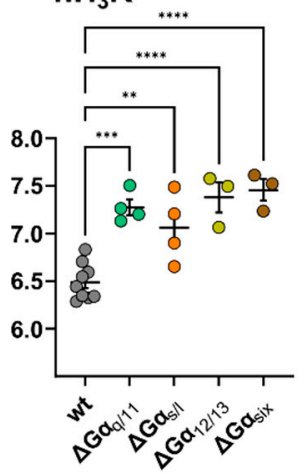

$\mathrm{hH}_{4} \mathrm{R}$

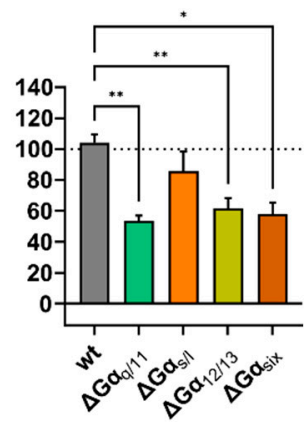

$\mathrm{hH}_{4} \mathrm{R}$

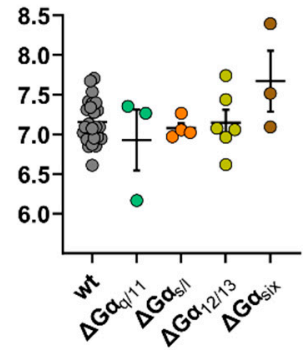

Figure 10. Effect of $G$ protein knock-out on the efficacy and potency of $\mathrm{HIS}$ at $\mathrm{hH}_{1-4} \mathrm{Rs}_{\text {s. }} \mathrm{E}_{\max }$ and pEC 50 values determined for HIS in $\triangle \mathrm{G} \alpha_{\mathrm{x}} \mathrm{HEK} \mathrm{hH}_{1-4} \mathrm{R}$ cells. (A) Bar chart of $\mathrm{E}_{\max }$ values determined

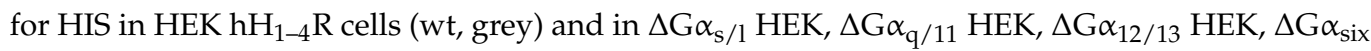
HEK cells each stably expressing $\mathrm{hH}_{1-4} \mathrm{Rs}$, respectively. The $\mathrm{E}_{\max }$ max values were calculated using $\mathrm{AUC}_{60}$ at the highest HIS concentration $\left(10 \mu \mathrm{M}\right.$ for $\mathrm{hH}_{1,2,4} \mathrm{R}$ and $100 \mu \mathrm{M}$ for $\left.\mathrm{hH}_{3} \mathrm{R}\right)$ and normalized to the mean $\mathrm{AUC}_{60}$ from $\mathrm{HEK} \mathrm{hH}_{1-4} \mathrm{R}$ cells at the corresponding receptor subtype $(100 \%)$ and to the corresponding buffer value $(0 \%)$ determined in $\Delta \mathrm{G} \alpha_{\mathrm{x}} \mathrm{HEK} \mathrm{hH}_{1-4} \mathrm{R}$ cells. (B) Scatter plot of the $\mathrm{pEC}_{50}$ values in $\mathrm{HEK} h \mathrm{H}_{1-4} \mathrm{R}$ cells (wt, grey) and in $\Delta \mathrm{G} \alpha_{\mathrm{s} / 1} \mathrm{HEK}, \Delta \mathrm{G} \alpha_{\mathrm{q} / 11} \mathrm{HEK}, \Delta \mathrm{G} \alpha_{12 / 13} \mathrm{HEK}, \Delta \mathrm{G} \alpha_{\text {six }}$ HEK cells each stably expressing $\mathrm{hH}_{1-4} \mathrm{Rs}$, respectively. The $\mathrm{pEC}_{50}$ were determined by plotting the $\mathrm{AUC}_{60}$ against the respective HIS concentration. $(\mathbf{A}, \mathbf{B})$ Data presented are means $\pm \mathrm{SEM}$ of at least three independent experiments each performed in triplicate. Statistical difference relative to the control was analyzed by one-way ANOVA followed by Dunnett's multiple comparison test. Significance levels are indicated by asterisks $\left({ }^{*} p \leq 0.05,{ }^{* *} p \leq 0.01,{ }^{* * *} p \leq 0.001,{ }^{* * * *} p \leq 0.0001\right)$.

Unlike $\mathrm{HEK}_{\mathrm{hH}} \mathrm{R}$ cells (all G proteins present) in which the DMR signal increased steadily but slowly after addition of HIS (Figure 2A), the DMR signal in all $\Delta \mathrm{G} \alpha_{\mathrm{x}}$ HEK $\mathrm{hH}_{3} \mathrm{R}$ cells increased rapidly, showing a peak within $10 \mathrm{~min}$ upon stimulation with HIS (Figure 9B). Interestingly, such a time course was not observed in any of the experiments in $\mathrm{HEK} \mathrm{hH}_{3} \mathrm{R}$ cells with $\mathrm{G} \alpha$ protein modulators (Figure $5 \mathrm{~B}$ ). The $\mathrm{E}_{\max }$ values of HIS in

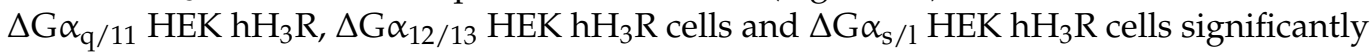
declined to $40 \pm 6.4 \%, 49 \pm 5.5 \%$ and $69 \pm 11 \%$, respectively, compared to the $100 \%$ control

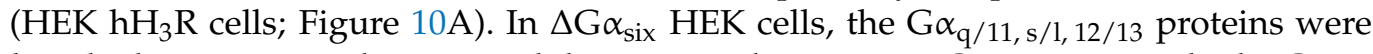
knocked-out, so it can be assumed that among the common $\mathrm{G} \alpha$ proteins, only the $\mathrm{G} \alpha_{\mathrm{i} / \mathrm{o}}$ was expressed. Upon stimulation of these cells with HIS, a weaker DMR response was detected with an $\mathrm{E}_{\max }$ value of $34 \pm 3.7 \%$ compared to $\mathrm{HEK}_{\mathrm{hH}} \mathrm{R}$ cells (Figure $10 \mathrm{~A}$ ). As the $\mathrm{G} \alpha_{\mathrm{i} / \mathrm{o}}$ signaling pathway is almost exclusively considered as physiologically relevant for the $\mathrm{hH}_{3} \mathrm{R}$, we did not expect a complete suppression of the signal in $\Delta \mathrm{G} \alpha_{\text {six }} \mathrm{HEK} \mathrm{hH}_{3} \mathrm{R}$ cells. However, before assigning this response solely to the $G \alpha_{i / o}$ protein, it should be noted that other $G$ proteins, such as $G \alpha_{z}$ should be considered. Strikingly, the $\mathrm{pEC}_{50}$ value 
determined for HIS in all $\Delta \mathrm{G} \alpha_{\mathrm{x}}$ HEK $\mathrm{hH}_{3} \mathrm{R}$ cells was significantly higher (Figure 10B) compared to that determined with $\mathrm{HEK}_{\mathrm{hH}} \mathrm{R}$ cells.

Different to the $\mathrm{hH}_{3} \mathrm{R}$, the time course of the HIS induced DMR response recorded using $\Delta \mathrm{G} \alpha_{\mathrm{x}} \mathrm{hH}_{4} \mathrm{R}$ cells (Figure 9) agreed well with that of $\mathrm{HEK} \mathrm{hH}_{4} \mathrm{R}$ cells (100\% control). The lack of $G \alpha_{\mathrm{q} / 11}$ in $\Delta \mathrm{G} \alpha_{\mathrm{q} / 11} \mathrm{HEK} \mathrm{hH}_{4} \mathrm{R}$ cells led to a significant decrease in the DMR signal to $54 \pm 3.3 \%$ (Figure $10 \mathrm{~A}$ ), whereas knock-out of $\mathrm{G} \alpha_{\mathrm{s}}\left(\Delta \mathrm{G} \alpha_{\mathrm{s}} \mathrm{HEK} \mathrm{hH}_{4} \mathrm{R}\right)$ showed a weaker impact on the DMR response, reducing the $\mathrm{E}_{\max }$ to $86 \pm 13 \%$ relative to the control. This was surprising because a much more pronounced suppression was observed after treatment with CTX. In $\Delta \mathrm{G} \alpha_{12 / 13} \mathrm{HEK} \mathrm{hH}_{4} \mathrm{R}$ cells, the $\mathrm{E}_{\max }$ value was suppressed to $62 \pm 6.7 \%$ compared to $\mathrm{HEK} \mathrm{hH}_{4} \mathrm{R}$ cells; therefore, it can be concluded that the $\mathrm{G \alpha}_{12 / 13}$ pathway seems to be involved in the signal transduction of the $\mathrm{hH}_{4} \mathrm{R}$ in HEK cells. The knock-out of the three subclasses of $\mathrm{G} \alpha$ proteins in $\Delta \mathrm{G} \alpha_{\text {six }} \mathrm{hH}_{4} \mathrm{R}$ cells reduced the $\mathrm{E}_{\max }$ value to $58 \pm 7.3 \%$ compared to $\mathrm{HEK} \mathrm{hH}_{4} \mathrm{R}$ cells, being in good agreement with results determined with the $G \alpha_{i / o}$ modulator PTX. However, as the other three $G$ proteins classes have been shown to be essentially involved in the signaling of the $\mathrm{hH}_{4} \mathrm{R}$ (see Section 2.3.1), we expected a more pronounced reduction of the signal. Perhaps the cells compensate for the lack of targeted $G$ proteins by enhanced expression of either $G \alpha_{i / o}$ or other $(G)$ proteins are involved in the signal transduction process.

\subsection{Pharmacological versus Molecular Biological Approach to Silence G $\alpha$ Protein}

The contribution of $\mathrm{G} \alpha$ proteins to the DMR response elicited by HIS at the $\mathrm{hH}_{1-4} \mathrm{Rs}$ stably expressed in HEK cells was investigated either by a classical pharmacological ( $\mathrm{G}$ protein modulators) or by a molecular biological ( $\mathrm{G} \alpha$ protein knock-out) approach In the pharmacological approach, $\mathrm{HEK} \mathrm{hH}_{1-4}$ Rs cells were pre-treated with $\mathrm{G} \alpha$ protein modulators FR, CTX and PTX to silence either $\mathrm{G} \alpha_{\mathrm{q} / 11}, \mathrm{G} \alpha_{\mathrm{S}}$ or $\mathrm{G} \alpha_{\mathrm{i} / \mathrm{o}}$ proteins, respectively (Section 2.3). In the molecular biological approach, the $G \alpha_{\mathrm{q} / 11}, \mathrm{G} \alpha_{\mathrm{s}}, \mathrm{G} \alpha_{12 / 13}$ proteins were knocked out individually or in combination (knock-out of $\mathrm{G} \alpha_{\mathrm{q} / 11, \mathrm{~s} / 1,12 / 13}$ ) using the CRISPR/Cas9 technology (Section 2.4). The focus of this section was to highlight the similarities and discuss the differences of the results obtained with these two approaches.

Silencing of the $\mathrm{G} \alpha_{\mathrm{q} / 11}$ signaling pathway either by $1.00 \mu \mathrm{M}$ FR in $\mathrm{HEK} \mathrm{hH}_{1-4} \mathrm{R}$ cells or by knocking out $\mathrm{G} \alpha_{\mathrm{q} / 11}$ in $\Delta \mathrm{G} \alpha_{\mathrm{q} / 11} \mathrm{HEK}_{\mathrm{hH}} \mathrm{H}_{1-4} \mathrm{R}$ cells have shown agreement in terms of $\mathrm{E}_{\max }$ and $\mathrm{pEC}_{50}$ values for HIS. At the $\mathrm{hH}_{1} \mathrm{R}$, for example, the time course of DMR traces were similarly altered by both approaches compared to the control (HEK $\mathrm{hH}_{1} \mathrm{R}$ cell w/o; Figure 11) and the $\mathrm{E}_{\max }$ for HIS was significantly reduced $\left(\Delta \mathrm{G} \alpha_{\mathrm{q} / 11}\right.$ $\mathrm{HEK} \mathrm{hH}_{1} \mathrm{R} \mathrm{E}_{\max }=46 \pm 3.8 ; \mathrm{HEK} \mathrm{hH}_{1} \mathrm{R}+1 \mu \mathrm{M}$ FR $\mathrm{E}_{\max }=41 \pm 9.5$ ) relative to HEK $\mathrm{hH}_{1} \mathrm{R}$ cells $\left(100 \% \mathrm{w} / \mathrm{o}\right.$ modulator). Moreover, both procedures to silence the $\mathrm{G} \alpha_{\mathrm{q} / 11}$ have led to a significant decrease in the $\mathrm{pEC}_{50}$ determined for $\mathrm{HIS}\left(\Delta \mathrm{G} \alpha_{\mathrm{q} / 11} \mathrm{HEK} \mathrm{hH}_{1} \mathrm{R}\right.$ $\mathrm{pEC}_{50}=6.38 \pm 0.02 ; \mathrm{HEK} \mathrm{hH}_{1} \mathrm{R}+1 \mu \mathrm{M}$ FR $\left.\mathrm{pEC}_{50}=6.60 \pm 0.29\right)$ relative to $\mathrm{HEK}_{\mathrm{hH}} \mathrm{R}$ control cells $\left(\mathrm{pEC}_{50}=7.43 \pm 0.05\right)$. A similar effect was observed for HIS with $\Delta \mathrm{G} \alpha_{\text {six }}$ HEK $\mathrm{hH}_{1} \mathrm{R}$ cells, which also lack the $\mathrm{G} \alpha_{\mathrm{q} / 11}$ protein. We expected such a pronounced perturbation of the $\mathrm{E}_{\max }$ and the $\mathrm{pEC}_{50}$ value, as $\mathrm{hH}_{1} \mathrm{R}$ is predominantly described as a $\mathrm{G} \alpha_{\mathrm{q} / 11}$ coupled receptor [57]. It was surprising that for the $\mathrm{hH}_{2} \mathrm{R}$, silencing of the $\mathrm{G} \alpha_{\mathrm{q} / 11}$ signaling pathway by both approaches (FR and $\mathrm{G} \alpha_{\mathrm{q} / 11}$ knock-out) had almost no impact on the DMR response (kinetics, $\mathrm{E}_{\max }$ and $\mathrm{pEC}_{50}$ ), as it is commonly accepted that the $\mathrm{G} \alpha_{\mathrm{q} / 11}$ protein is considerably involved in the signal transduction of the $\mathrm{hH}_{2} \mathrm{R}$ [56]. We cannot confirm this in the DMR assay using HEK cells. By contrast, deactivation of the $\mathrm{G} \alpha_{\mathrm{q} / 11}$ signaling pathway either by FR or knock-out affected the $E_{\max }$ value for HIS at $\mathrm{hH}_{3,4} \mathrm{Rs}$ (Figure 11). In HEK hH $\mathrm{H}_{3,4} \mathrm{Rs}, 1.00 \mu \mathrm{M}$ FR reduced the $\mathrm{E}_{\max }$ to $57 \pm 5.4 \%$ and $47 \pm 4.5 \%$, respectively (Figure $6 \mathrm{~A}$ ) and in $\Delta \mathrm{G} \alpha_{\mathrm{q} / 11} \mathrm{HEK} \mathrm{hH}_{3,4} \mathrm{R}$ cells the $\mathrm{E}_{\max }$ was diminished to $40 \pm 6.4 \%$ and $54 \pm 3.3 \%$, respectively (Figure 10A; compared to untreated $\mathrm{HEK} \mathrm{hH}_{3,4} \mathrm{R}$ cells). Moreover, at $\mathrm{hH}_{3} \mathrm{R}$, the $\mathrm{pEC}_{50}$ value for HIS increased significantly by both approaches $\left(\mathrm{HEK} \mathrm{hH}_{3} \mathrm{R}+1 \mu \mathrm{M}\right.$ FR pEC $50=7.20 \pm 0.05, \Delta \mathrm{G} \alpha_{\mathrm{q} / 11} \mathrm{HEK} \mathrm{hH}_{3} \mathrm{R}$ cells $\left.\mathrm{pEC}_{50}=7.28 \pm 0.08\right)$ relative to $\mathrm{HEK}_{\mathrm{hH}} \mathrm{R}$ cells $\left(\mathrm{pEC}_{50}=6.49 \pm 0.06\right)$. By contrast, in both systems the $\mathrm{pEC}_{50}$ determined for $\mathrm{HIS}$ at the $\mathrm{hH}_{4} \mathrm{R}$ was not significantly altered. As both 
approaches led to the same consequences, we are convinced that the results are not an artifact and conclude that $\mathrm{G} \alpha_{\mathrm{q} / 11}$ contributed to the DMR signaling of the $\mathrm{hH}_{3,4} \mathrm{Rs}$ in HEK cells, even though the limited literature suggests the opposite $[91,101]$. We consider this as an intriguing starting point for further investigations.
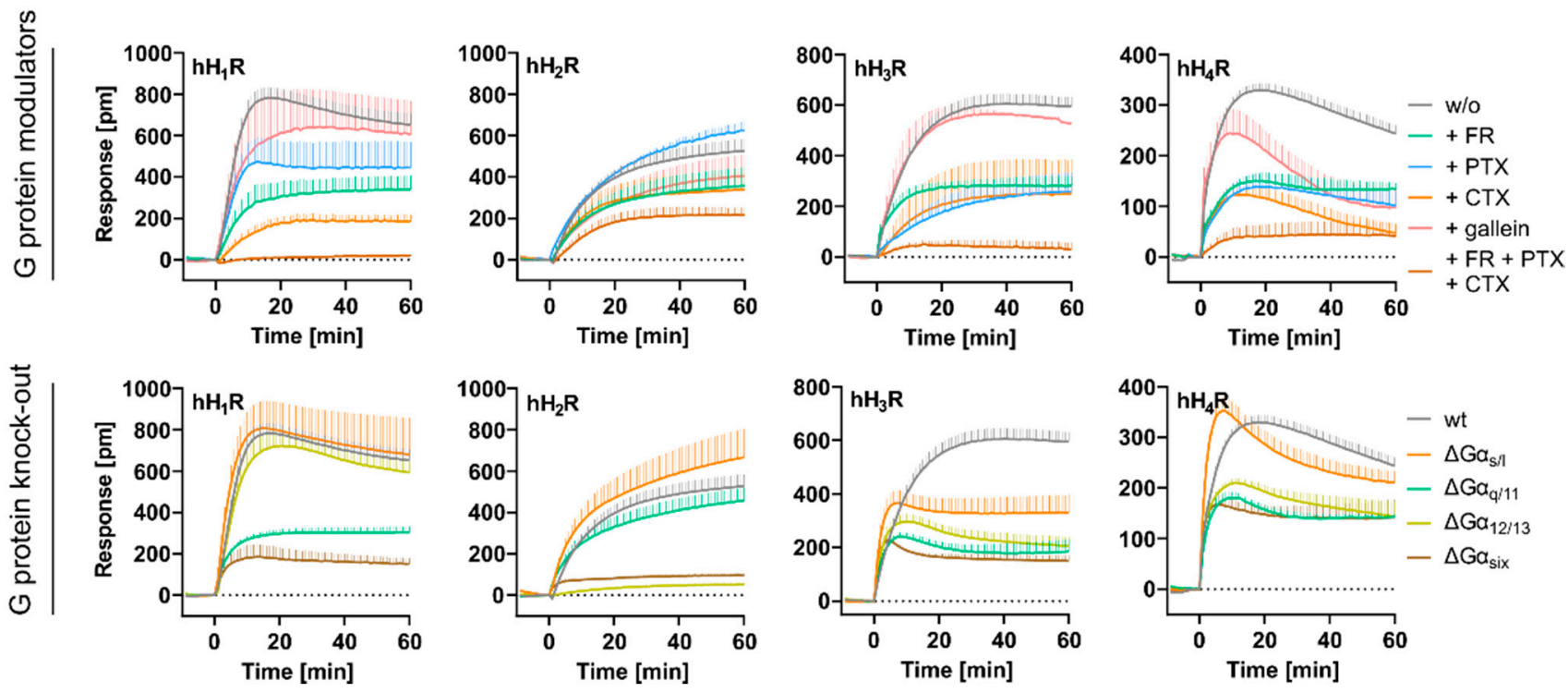

Figure 11. G protein inhibition using a classical pharmacological concept (G protein modulator) or by a molecular biological approach (G $\alpha$ protein knock-out cells). DMR traces recorded for HIS in $\mathrm{HEK} \mathrm{hH}_{1-4} \mathrm{R}$ cells in the absence (w/o modulator) or presence of $\mathrm{G}$ protein modulators (100 ng/mL PTX, $100 \mathrm{ng} / \mathrm{mL}$ CTX, $1 \mu \mathrm{M}$ FR, $20 \mu \mathrm{M}$ gallein (gal) and combination of $10 \mathrm{ng} / \mathrm{mL} \mathrm{PTX}+10 \mathrm{ng} / \mathrm{mL} \mathrm{CTX}+1 \mu \mathrm{M}$ FR) or in G $\alpha$ protein knock-out cells $\left(\Delta \mathrm{G} \alpha_{\mathrm{s} / 1} \mathrm{HEK}, \Delta \mathrm{G} \alpha_{\mathrm{q} / 11} \mathrm{HEK}, \Delta \mathrm{G} \alpha_{12 / 13} \mathrm{HEK}\right.$ and $\Delta \mathrm{G} \alpha_{\text {six }}$ HEK cells) stably transfected with $\mathrm{hH}_{1-4}$ Rs. In the case of the $\mathrm{hH}_{1,2,4}$ Rs the cells were stimulated with $10 \mu \mathrm{M}$ HIS, whereas in the case of the $\mathrm{hH}_{3} \mathrm{R}$ the cells were stimulated with $100 \mu \mathrm{M}$ HIS. All traces shown were corrected for the assay buffer and represent means \pm SEM of at least three independent experiments, each performed in triplicate.

Unlike $\mathrm{G} \alpha_{\mathrm{q} / 11}$, we found differences between CTX and knocking-out $\mathrm{G} \alpha_{\mathrm{s}}$ (Figure 11).

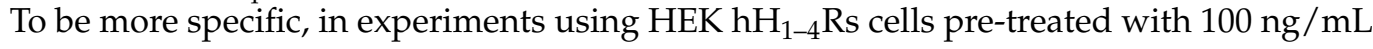
CTX, we concluded that $\mathrm{G} \alpha_{\mathrm{s}}$ was markedly involved in the $\mathrm{hH}_{1-4} \mathrm{R}$ mediated signal transduction process in HEK cells throughout. For example, for the $\mathrm{hH}_{1} \mathrm{R}$ the $\mathrm{E}_{\max }$ was dramatically reduced to $23 \pm 4.9 \%$ (Figure $6 \mathrm{~A}$ ). Moreover, the $\mathrm{E}_{\max }$ of HIS determined in $\mathrm{HEK} \mathrm{hH}_{3,4} \mathrm{R}$ cells was significantly reduced to $54 \pm 7.6 \%$ or $35 \pm 7.9 \%$, respectively (Figures 5 and $6 \mathrm{~A}$ ). By contrast, we observed that knock-out of $\mathrm{G} \alpha_{\mathrm{s} / 1}$ in $\Delta \mathrm{G} \alpha_{\mathrm{s} / 1}$ HEK $\mathrm{hH}_{1-4} \mathrm{R}$ cells had a weaker effect on the $\mathrm{E}_{\max }$ value. In $\Delta \mathrm{G} \alpha_{\mathrm{s} / 1} \mathrm{HEK} \mathrm{hH}_{1,3,4} \mathrm{R}$ cells, the $\mathrm{E}_{\max }$ value amounted to $115 \pm 23 \%, 69 \pm 12 \%$ and $86 \pm 13 \%$ of control responses respectively (Figure 10A), suggesting that $\mathrm{G} \alpha_{\mathrm{s}}$ plays a supporting role in the HIS induced DMR response. Various explanations can be considered to address this discrepancy in $\mathrm{E}_{\max }$ between the two approaches. On the one hand, it seems possible that HEK cells have "adapted" their repertoire of expressed $\mathrm{G} \alpha$ proteins to compensate for the lack of $\mathrm{G} \alpha_{\mathrm{s}}$ in $\Delta \mathrm{G} \alpha_{\mathrm{s} / \mathrm{l}}$ HEK $\mathrm{hH}_{1-4} \mathrm{R}$ cells so that the $\mathrm{E}_{\max }$ remained unaffected. On the other hand, it is conceivable that, in addition to $G \alpha_{S}, C T X$ may have off-target effects that were relevant for the generation of the DMR signal in $\mathrm{HEK} \mathrm{hH}_{1-4} \mathrm{R}$ cells, which led to a decrease in $\mathrm{E}_{\max }$. Elucidation of the difference in results between the pharmacological and molecular biological approaches for $\mathrm{G} \alpha_{\mathrm{s}}$ modulation should be pursued in the future.

Regarding the $G \alpha_{i / o}$ signaling pathway, in the experiments with PTX we found that $\mathrm{G} \alpha_{\mathrm{i} / \mathrm{o}}$ was directly involved in the $\mathrm{hH}_{1} \mathrm{R}$ mediated DMR response in HEK cells, as the $\mathrm{E}_{\max }$ was reduced to $50 \pm 9.3 \%$ in the presence of $100 \mathrm{ng} / \mathrm{mL}$ PTX (Figure 6A). Alternatively, in $\Delta \mathrm{G} \alpha_{\text {six }} \mathrm{hH}_{1} \mathrm{R}$ cells, which among the canonical $\mathrm{G} \alpha$ proteins only express $\mathrm{G} \alpha_{\mathrm{i} / \mathrm{o}}$, HIS elicited a DMR response with a corresponding $\mathrm{E}_{\max }$ of $33 \pm 0.5 \%$ (Figure $10 \mathrm{~A}$ ). As we ruled out that $\mathrm{G} \alpha_{12 / 13}$ and $\mathrm{G} \alpha_{\mathrm{z}}$ play a role in the $\mathrm{hH}_{1} \mathrm{R}$ mediated DMR response (Figure 7), we conclude 
that the residual $33 \%$ represent the interaction of the $\mathrm{hH}_{1} \mathrm{R}$ with the $\mathrm{G} \alpha_{\mathrm{i} / \mathrm{o}}$, in accordance with literature [57]. The $\mathrm{hH}_{3,4} \mathrm{Rs}$ are considered as $\mathrm{G} \alpha_{\mathrm{i} / \mathrm{o}}$ selective receptors [57], however, according to our experiments, we conclude that $G \alpha_{i / o}$ was not exclusively involved in the manifestation of the DMR signal in $\mathrm{HEK} \mathrm{hH}_{3,4} \mathrm{R}$ cells. Namely, pretreatment of HEK $\mathrm{hH}_{3,4} \mathrm{R}$ cells with $100 \mathrm{ng} / \mathrm{mL}$ of PTX led to a dramatic decrease in $\mathrm{E}_{\max }$, and the $\mathrm{pEC}_{50}$ was reduced in $\mathrm{HEK} \mathrm{hH}_{3} \mathrm{R}$ cells compared to controls (Figure 6B). Additionally, in the presence of the $G \alpha_{\mathrm{q} / 11}$ protein modulator $F R$, the $\mathrm{E}_{\max }$ was significantly reduced for both receptor subtypes (Figure 6B). Moreover, it was not possible to completely abolish the HIS triggered DMR in HEK $\mathrm{hH}_{3,4} \mathrm{R}$ cells with a modulator cocktail comprising FR, CTX and PTX (Figure 7). In addition to the canonical $G \alpha$ proteins, we observed that the $G \alpha_{12 / 13}$ proteins might be involved in the signal transduction process of the $\mathrm{hH}_{3,4} \mathrm{Rs}$, as the $\mathrm{E}_{\max }$

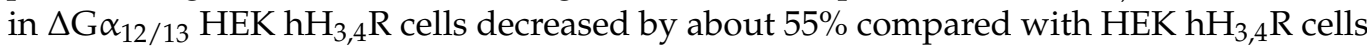
(Figure 10A). However, we cannot exclude that the $\mathrm{G} \alpha_{\mathrm{z}}$ might also be involved. In the case of the $\mathrm{hH}_{2} \mathrm{R}$, the modulation of $\mathrm{G} \alpha_{\mathrm{i} / \mathrm{o}}$ by $100 \mathrm{ng} / \mathrm{mL}$ PTX had a weaker effect on the HIS induced DMR response ( $\mathrm{E}_{\max }=77 \pm 4.1 \%$ ) compared to the $\mathrm{hH}_{1,3,4} \mathrm{Rs}\left(\mathrm{E}_{\max } 51-32 \%\right.$; Figure 6A). Moreover, we failed to suppress the HIS induced DMR response by more than $40 \%$ with G $\alpha$ protein modulators FR, CTX and PTX (Figure 7), and most of the DMR signal

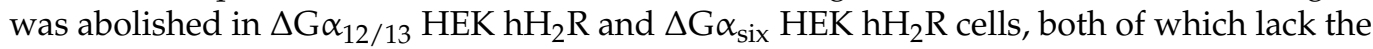
$\mathrm{G} \alpha_{12 / 13}$ protein (Figure 10A). We conclude that $\mathrm{G} \alpha_{\mathrm{q} / 11}, \mathrm{G} \alpha_{\mathrm{s}}$, and $\mathrm{G} \alpha_{\mathrm{i} / \mathrm{o}}$ played a minor role in the generation of the HIS DMR signal in $\mathrm{HEK} h \mathrm{H}_{2} \mathrm{R}$ cells, and that $\mathrm{G} \alpha_{12 / 13}$ proteins must have been involved. It has already been described in the literature that the $\mathrm{hH}_{2} \mathrm{R}$ is capable to interact with the $\mathrm{G} \alpha_{12 / 13}$ protein [59,60], however, it was unexpected that the involvement of $\mathrm{G} \alpha_{12 / 13}$ would exceed the contribution of $\mathrm{G} \alpha_{\mathrm{q} / 11}, \mathrm{G} \alpha_{\mathrm{s}}$, and $\mathrm{G} \alpha_{\mathrm{i} / \mathrm{o}}$.

In summary, we successfully established a DMR assay for the entire histaminergic receptor family stably expressed in HEK cells, providing an opportunity to monitor the functions of HRs and its ligands in real-time. High S/B-ratios above 100 for HIS and 24 for inverse agonists facilitate investigations on signaling pathways of $\mathrm{hH}_{1-4} \mathrm{Rs}$ and might be beneficial for further investigations, e.g., with respect to inverse agonism and functional bias of HR ligands. We took advantage of the integrative nature of the DMR assay to investigate the involvement of endogenously expressed $G$ proteins in the signaling transduction processes mediated by $\mathrm{hH}_{1-4}$ Rs. However, in view of the physiological relevance of the results, experiments with cells or tissues which endogenously express the receptors are pending. For example, using modulatory tools such as PTX, CTX and FR, the impact of ligands on the signaling pathway of the receptor can be studied as well, which is particularly interesting with respect to ligand induced signal bias. At this point, it should be noted that apart from $G$ proteins, the recruitment of $\beta$-arrestin also plays an important role in the signal transduction processes of GPCRs [24] and consequently also for HRs [102-104]. Interestingly, although investigations on the mechanistic details of $\beta$-arrestin activation are available, there is also evidence that no $\beta$-arrestin mediated signaling was observed in absence of functional $\mathrm{G}$ proteins [41]. The DMR assay could be a valuable approach to investigate the contribution of $\beta$-arrestins to a holistic response of HRs. Pharmacological tools (e.g., biased ligands, protein inhibitors) in combination with a molecular biological approach (e.g., cells lacking (either) $\mathrm{G} \alpha$ proteins and/or $\beta$-arrestins) might be helpful to gain new insights into the interaction of $G$ proteins and $\beta$-arrestins [41]. Moreover, several polymorphisms were discovered for HRs [105] which are under investigation to be associated with diseases such as heart failure $\left(\mathrm{H}_{2} \mathrm{R}\right.$ [106]) or allergic rhinitis $\left(\mathrm{H}_{4} \mathrm{R}\right.$ [107]) and correlated with the effectiveness of drugs $\left(\mathrm{H}_{1} \mathrm{R}\right.$ [108], $\mathrm{H}_{3} \mathrm{R}$ [109], $\mathrm{H}_{4} \mathrm{R}$ [110]). Thus, the DMR assay might be a valuable tool to characterize such polymorphisms of HRs, especially focusing on the differences in the signaling pathways between receptor variants.

Although our studies still leave some open questions, we are convinced that the presented work provides valuable information for further investigation on signal transduction mechanisms of the HR family. 


\section{Materials and Methods}

\subsection{Materials}

Dulbecco's modified Eagle's medium with phenol red (DMEM), L-glutamine solution $(200 \mathrm{mM})$ and penicillin-streptomycin solution $(10,000$ units penicillin and $10 \mathrm{mg}$ streptomycin per $\mathrm{mL}$ in $0.9 \% \mathrm{NaCl}$ ) were purchased from Sigma-Aldrich (Taufkirchen, Germany). Hanks' Balanced Salt Solution (HBSS) and Leibovitz' L-15 medium (L-15) were from Fisher Scientific (Nidderau, Germany). FBS, and geneticin (G418) were from Merck Biochrom (Darmstadt, Germany). Trypsin/EDTA was either from Merck Biochrom (Darmstadt, Germany) or from VWR International GmbH (Ismaning, Germany). The pIRESpuro3 vector was a gift from Prof. Dr. Gunter Meister (Biochemistry I, University of Regensburg, Regensburg, Germany). Histamine dihydrochloride (HIS), was from Fisher Scientific (Schwerte, Germany). Diphenhydramine hydrochloride (DPH), mepyramine maleate (MEP) and famotidine (FAM) were from Sigma (Taufkirchen, Germany). Thioperamide maleate (THIO), UR-DE257 (DE257) and JNJ7777120 (JNJ) were synthesized in-house according to standard procedures. Pitolisant hydrochloride (PIT) was kindly provided by Prof. Dr. Katarzyna Kiec-Kononowicz (Jagiellonian University, Krakow, Poland). The ligands were dissolved in Millipore water, except for famotidine (FAM), which was dissolved in DMSO (Merck, Darmstadt, Germany). FR900359 (UBO-QIC) was purchased from the Institute of Pharmaceutical Biology, University of Bonn (Bonn, Germany). Pertussis Toxin (PTX) was purchased from Bio-Techne GmbH (Wiesbaden, Germany) and Cholera Toxin from Enzo Life Sciences (Lörrach, Germany). Gallein was from Santa Cruz Biotechnology (Heidelberg, Germany).

\subsection{Cell Culture}

\subsubsection{Parental Cells and General Culture Conditions}

HEK293T cells were a kindly provided by Prof. Dr. Wulf Schneider (Institute for Medical Microbiology and Hygiene, Regensburg, Germany). HEK293T and CRISPR/Cas9 edited HEK293A lacking the $\mathrm{G} \alpha$ proteins $\mathrm{G} \alpha_{\mathrm{s}}+\mathrm{G} \alpha_{\text {olf }}\left(\Delta \mathrm{G} \alpha_{\mathrm{s} / 1}\right.$ HEK) [63], $\mathrm{G} \alpha_{\mathrm{q}}+\mathrm{G} \alpha_{11}$ $\left(\Delta \mathrm{G} \alpha_{\mathrm{q} / 11}\right.$ HEK) [44], $\mathrm{G} \alpha_{12}+\mathrm{G} \alpha_{13}\left(\Delta \mathrm{G} \alpha_{12 / 13}\right.$ HEK) [64] or $\mathrm{G} \alpha_{\mathrm{q}}+\mathrm{G} \alpha_{\text {olf }}+\mathrm{G} \alpha_{11}+\mathrm{G} \alpha_{\mathrm{s}}+$ $\mathrm{G} \alpha_{12}+\mathrm{G} \alpha_{13}\left(\Delta \mathrm{G} \alpha_{\text {six }}\right.$ HEK) [41] were maintained in DMEM supplemented with $10 \%$ FBS, penicillin $(100 \mathrm{U} / \mathrm{mL})$ and streptomycin $(100 \mu \mathrm{g} / \mathrm{mL})(\mathrm{P} / \mathrm{S})$ at $37^{\circ} \mathrm{C}$ in a water-saturated atmosphere containing $5 \% \mathrm{CO}_{2}$. Cells were periodically monitored for mycoplasma contamination by means of the Venor GeM Mycoplasma Detection Kit (Minerva Biolabs, Berlin, Germany) and proven negative.

\subsubsection{Generation of $\mathrm{HEK}_{\mathrm{hH}} \mathrm{H}_{1-4} \mathrm{R}$ Cells}

The HEK $h H_{1} R$, HEK $h H_{2} R$, HEK $h_{3}$ R and $H E K h_{4} R$ cells are abbreviated designations of the previously described stable single clone transfectants: HEK293T-SP-FLAG$\mathrm{hH}_{1} \mathrm{R}$ K12 [111], HEK293T-SP-FLAG-hH ${ }_{2} \mathrm{R}$ K46 [111], HEK293T-SP-FLAG-hH 3 R K16 [89] and HEK293T-SP-FLAG-hH ${ }_{4} \mathrm{R}$ K3 cells [89], respectively. The procedures for molecular cloning of the receptors and the generation of the stable cell lines are described elsewhere $[89,111]$. The cells were cultured in DMEM supplemented with $10 \% \mathrm{FBS}+\mathrm{P} / \mathrm{S}$ and $600 \mu \mathrm{g} / \mathrm{mL}$ G418.

\subsubsection{Generation of $\Delta \mathrm{G} \alpha_{\mathrm{x}} \mathrm{HEK}_{\mathrm{hH}} \mathrm{H}_{1-4} \mathrm{R}$ Cells}

For the generation of $\Delta \mathrm{G} \alpha_{\mathrm{x}}$ HEK $\mathrm{hH}_{1-4} \mathrm{R}$ cells CRISPR/Cas9 modified HEK293A cells lacking the $\mathrm{G} \alpha$ proteins $\mathrm{G} \alpha_{\mathrm{s}}+\mathrm{G} \alpha_{\text {olf }}\left(\Delta \mathrm{G} \alpha_{\mathrm{s} / 1} \mathrm{HEK}\right)$ [63], $\mathrm{G} \alpha_{\mathrm{q}}+\mathrm{G} \alpha_{11}\left(\Delta \mathrm{G} \alpha_{\mathrm{q} / 11} \mathrm{HEK}\right)$ [44], $\mathrm{G} \alpha_{12}+\mathrm{G} \alpha_{13}\left(\Delta \mathrm{G} \alpha_{12 / 13}\right.$ HEK) [64] or $\mathrm{G} \alpha_{\mathrm{q}}+\mathrm{G} \alpha_{\text {olf }}+\mathrm{G} \alpha_{11}+\mathrm{G} \alpha_{\mathrm{s}}+\mathrm{G} \alpha_{12}+\mathrm{G} \alpha_{13}\left(\Delta \mathrm{G} \alpha_{\text {six }}\right.$ HEK) [41] were transfected with the pIRESneo3-SP-FLAG vector encoding the $\mathrm{hH}_{1-4} \mathrm{Rs}$ according to the procedure described for $\mathrm{HEK}_{\mathrm{hH}} \mathrm{R}$ cells [89] except that no single clone selection was performed. The cells were cultured in DMEM supplemented with 10\% $\mathrm{FBS}+\mathrm{P} / \mathrm{S}$ and $600 \mu \mathrm{g} / \mathrm{mL}$ G418. 


\subsection{Methods}

\subsubsection{Radioligand Binding}

All radioligand binding experiments (saturation and competition) were performed using suspensions of live HEK $h H_{1-4} \mathrm{R}$ and $\Delta \mathrm{G} \alpha_{\mathrm{x}} \mathrm{HEK} \mathrm{hH}_{1-4} \mathrm{R}$ cells. The cells were cultivated in DMEM supplemented with 10\% FBS + P/S and $600 \mu \mathrm{g} / \mathrm{mL}$ G418 until 90-100\% confluency was reached. On the day of the assay, the cells were detached by trypsinization (0.05\% trypsin, $0.02 \%$ EDTA in PBS, at $37{ }^{\circ} \mathrm{C}$ for $2-4 \mathrm{~min}$ ), harvested by centrifugation $(800 \times g$ at $\mathrm{rt}$ for $5 \mathrm{~min}$ ) and resuspended in L-15 medium devoid of additional supplements. The number of cells was determined using a hemocytometer (Neubauer, improved) and the cell density was adjusted to $1.0 \times 10^{6}$ cells $/ \mathrm{mL}$.

Before dispensing the cell suspension, all (radio)ligand dilutions were prepared 10fold concentrated in L-15 medium and dispensed (10 $\mu \mathrm{L} /$ well) in 96 well plates (PP microplates, Greiner Bio-One, Frickenhausen, Germany). Total binding was determined in the presence of L-15 medium ( $10 \mu \mathrm{L} /$ well), and the non-specific binding was assessed in the presence of a competitor: for $\mathrm{hH}_{1} \mathrm{R}$ diphenhydramine (DPH), for $\mathrm{hH}_{2} \mathrm{R}$ famotidine (FAM), for $\mathrm{hH}_{3,4} \mathrm{Rs}$ histamine (HIS), each at a final concentration of $10 \mu \mathrm{M}$. For saturation binding experiments, serial dilutions of the following radioligands were prepared $\left(10 \mu \mathrm{L} /\right.$ well): $\left[{ }^{3} \mathrm{H}\right] \mathrm{MEP}\left(\mathrm{a}_{\mathrm{s}}=20 \mathrm{Ci} / \mathrm{mM}\right.$, Hartmann Analytics $\mathrm{GmbH}$, Braunschweig, Germany) for the $\mathrm{hH}_{1} \mathrm{R},\left[{ }^{3} \mathrm{H}\right] \mathrm{UR}-\mathrm{DE} 257\left(\mathrm{a}_{\mathrm{s}}=32.9 \mathrm{Ci} / \mathrm{mmol}\right)$ [69] for the $\mathrm{hH}_{2} \mathrm{R}$ and $\left[{ }^{3} \mathrm{H}\right] \mathrm{UR}-$ PI294 $\left(\mathrm{a}_{\mathrm{s}}=93.3 \mathrm{Ci} / \mathrm{mmol}\right)$ [70] for the $\mathrm{hH}_{3,4}$ Rs. For competition binding experiments, dilutions of "cold" ligands (10 $\mu \mathrm{L} /$ well) were incubated in the presence of $\left.5 \mathrm{nM} \mathrm{[}{ }^{3} \mathrm{H}\right] \mathrm{MEP}$ for the $\mathrm{hH}_{1} \mathrm{R}, 50 \mathrm{nM}\left[{ }^{3} \mathrm{H}\right]$ UR-DE257 for the $\mathrm{hH}_{2} \mathrm{R}, 2 \mathrm{nM}\left[{ }^{3} \mathrm{H}\right] \mathrm{UR}-\mathrm{PI} 294$ for the $\mathrm{hH}_{3} \mathrm{R}$ and $5 \mathrm{nM}\left[{ }^{3} \mathrm{H}\right] \mathrm{UR}-\mathrm{PI} 294$ for the $\mathrm{hH}_{4} \mathrm{R}$.

Subsequently, the cell suspension was added to the (radio)ligands ( $80 \mu \mathrm{L} /$ well) to reach a final assay volume of $100 \mu \mathrm{L} /$ well. After an incubation period of 60-120 min, the cells were harvested by filtration using a Brandel 96 sample harvester and the radioactivity was determined by liquid scintillation counting as described previously [112].

Data was analyzed using the GraphPad Prism 8 or 9 software (San Diego, CA, USA). Specific binding was calculated by subtracting the non-specific binding from the total binding. For saturation binding experiments binding data was plotted against the free radioligand concentration $(\mathrm{nM})$ and best fitted to a one site saturation binding model (one site- total and non-specific binding; one site-specific binding) yielding $\mathrm{K}_{\mathrm{d}}$ values. Receptor expression was quantified using the extrapolated $B_{\max }$ values, specific activity $\left(a_{s}\right)$ of the radioligands and the cell number seeded per well and is indicated as specific binding sites per cell.

For competition binding experiments, the specific binding was plotted against the $-\log$ (concentration ligand) and analyzed applying the four parameters logistic equation ( $\log$ (modulator) vs. response-variable slope (four parameters)) yielding the $\mathrm{pIC}_{50}$ values, which were individually converted to pKi values using the Cheng-Prusoff equation [113].

\subsubsection{DMR Assay}

The DMR assay was essentially performed as described [38] with the following modifications: The cells were cultured in DMEM supplemented with 10\% FBS, $2 \mathrm{mM}$ L-glutamine, $\mathrm{P} / \mathrm{S}$, and $600 \mu \mathrm{g} / \mathrm{mL}$ G418 until $90-100 \%$ confluency. The day before the assay, the cells were detached by trypsinization $(0.05 \%$ trypsin, $0.02 \%$ EDTA in PBS, at $37^{\circ} \mathrm{C}$ for $\left.2-4 \mathrm{~min}\right)$, harvested by centrifugation $(800 \times \mathrm{g}, \mathrm{RT}, 5 \mathrm{~min}$,) and subsequently resuspended in DMEM supplemented with $10 \% \mathrm{FBS}+\mathrm{P} / \mathrm{S}$ w $/$ o G418. The cell density was adjusted to $1 \times 10^{6}$ cells $/ \mathrm{mL}$ and the cell suspension was dispensed $(90 \mu \mathrm{L} /$ well $)$ into an uncoated label-free 96 well plate (Cat. No. 5080, Corning B.V. Life Sciences, Amsterdam, Netherlands). Subsequently, the cells were spun down at $600 \times g$ for $1 \mathrm{~min}$ and allowed to attach in a humidified atmosphere containing $5 \% \mathrm{CO}_{2}$ at $37^{\circ} \mathrm{C}$ overnight. On the day of the measurement, the cells were gently washed twice with assay medium (HBSS containing $20 \mathrm{mM}$ HEPES). After the last washing step, the final volume was adjusted to $90 \mu \mathrm{L} /$ well with assay medium and the plate was centrifuged at $600 \times g$ for $1 \mathrm{~min}$. The 
cells were allowed to equilibrate at $37^{\circ} \mathrm{C}$ for at least $2 \mathrm{~h}$ in an EnSpire multimode plate reader (PerkinElmer, Rodgau, Germany), before the baseline was recorded every minute for 5-10 min. Immediately after the baseline record, the compounds ( $10 \mu \mathrm{L} /$ well; 10 -fold concentrated in assay medium) were added and the response was recorded every minute for $60 \mathrm{~min}$.

For experiments with the G-protein modulators PTX and CTX the cells were pretreated with the modulator at the respective final concentration $(1.00,10.0$ or $100 \mathrm{ng} / \mathrm{mL})$ overnight and the assay was performed as described above. In the case of FR900359 and gallein the cells were incubated with the modulator (FR900359 1.00, 0.10 or $0.01 \mu \mathrm{M}$; gallein $20.0 \mu \mathrm{M}$ ) for $30 \mathrm{~min}$ before the baseline record. Afterwards the assay was performed by analogy with the procedure described above.

The time course data is presented as resonance wave-length shift in pm relative to the last data point before the test compounds were added at time zero. Data were analyzed using the GraphPad Prism 8 and 9 software (San Diego, CA, USA). For analysis, the data were corrected for the baseline drift by subtracting the mean values of the buffer control. Subsequently, the area under curve (AUC) was calculated individually for each well defining the first $5-10$ values as baseline. For the estimation of the S/B ratios the modulus of the AUC was used according to the following equation.

$$
\frac{\mathrm{S}}{\mathrm{B}} \text { ratio }=\frac{\left|A U C_{\text {signal }}\right|}{\left|A U C_{\text {buffer }}\right|}
$$

Corresponding to the signal deflection (positive or negative) the positive or the negative AUC was used for the construction of concentration response curves. The AUCs were normalized to the maximum response elicited by the highest histamine concentration $(100 \%$ control) and assay medium ( $0 \%$ control) and plotted against the logarithmic ligand concentration. The $\mathrm{pEC}_{50}$ values were calculated by applying the four parameters logistic equation ( $\log$ (agonist) vs. response-variable slope (four parameters)). Real-time DMR traces are presented from representative experiments (mean \pm SEM) with each trace reflecting the average of three technical replicates. Each experiment was performed at least three times to obtain at least three independent biological replicates.

\subsection{Statistical Analyses}

Statistical differences were analyzed using either the student $t$ test (two-tailed) or oneway ANOVA followed by Dunnett's or Tukey's multiple comparisons test, as indicated in the corresponding Figures/Tables. All calculated $p$-values are two-sided and considered as statistically significant when lower than 0.5 indicated as ${ }^{*} p \leq 0.05,{ }^{* *} p \leq 0.01$, ${ }^{* * *} p \leq 0.001$, $* * * * p \leq 0.0001$. All calculations were performed using the GraphPad Prism 8 or 9 software (San Diego, CA, USA).

Supplementary Materials: The following supplementary Materials are available online at https: //www.mdpi.com/article/10.3390/ijms22189739/s1.

Author Contributions: Conceptualization, U.S.-E. and G.B.; methodology, U.S.-E. and N.P.; validation, U.S.-E.; formal analysis, U.S.-E.; investigation, U.S.-E. and N.P.; resources, A.I., G.B. and A.S.; data curation, U.S.-E.; writing—original draft preparation, U.S.-E.; writing-review and editing, U.S.-E., N.P., A.I., G.B. and A.S.; visualization, U.S.-E.; supervision, G.B. and A.S.; project administration, U.S.-E.; funding acquisition, A.S. All authors have read and agreed to the published version of the manuscript.

Funding: This work was supported by the Graduate Training Program GRK 1910 of the Deutsche Forschungsgemeinschaft (A.S.). A.I. was funded by the PRIME 19gm5910013, the LEAP $20 \mathrm{gm} 0010004$ and the BINDS JP20am0101095 from the Japan Agency for Medical Research and Development (AMED); KAKENHI 21H04791 from the Japan Society for the Promotion of Science (JSPS).

Institutional Review Board Statement: Not applicable. 
Informed Consent Statement: Not applicable.

Data Availability Statement: The data presented in this study are available on request from the first author.

Acknowledgments: We are grateful to Maria Beer-Krön, Valerie Huber and Bettina Brechenmacher for excellent technical assistance. We are grateful to Laura Humphrys for proofreading and editing the manuscript. Moreover, we want to thank Lukas Grätz and Timo Littmann for their scientific

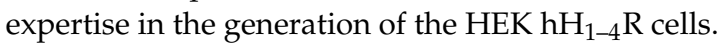

Conflicts of Interest: The authors declare no conflict of interest. The funders had no role in the design of the study; in the collection, analyses, or interpretation of data; in the writing of the manuscript, or in the decision to publish the results.

\section{References}

1. Katritch, V.; Cherezov, V.; Stevens, R.C. Structure-function of the G protein-coupled receptor superfamily. Annu. Rev. Pharmacol. Toxicol. 2013, 53, 531-556. [CrossRef]

2. Hauser, A.S.; Attwood, M.M.; Rask-Andersen, M.; Schioth, H.B.; Gloriam, D.E. Trends in GPCR drug discovery: New agents, targets and indications. Nat. Rev. Drug Discov. 2017, 16, 829-842. [CrossRef] [PubMed]

3. Milligan, G.; Kostenis, E. Heterotrimeric G-proteins: A short history. Br. J. Pharm. 2006, 147 (Suppl. 1), S46-S55. [CrossRef] [PubMed]

4. Kristiansen, K. Molecular mechanisms of ligand binding, signaling, and regulation within the superfamily of G-protein-coupled receptors: Molecular modeling and mutagenesis approaches to receptor structure and function. Pharmacol. Ther. 2004, 103, 21-80. [CrossRef] [PubMed]

5. Smrcka, A.V. G protein betagamma subunits: Central mediators of G protein-coupled receptor signaling. Cell Mol. Life Sci. 2008, 65, 2191-2214. [CrossRef] [PubMed]

6. Khan, S.M.; Sleno, R.; Gora, S.; Zylbergold, P.; Laverdure, J.P.; Labbe, J.C.; Miller, G.J.; Hebert, T.E. The expanding roles of Gbetagamma subunits in G protein-coupled receptor signaling and drug action. Pharm. Rev. 2013, 65, 545-577. [CrossRef]

7. Hur, E.M.; Kim, K.T. G protein-coupled receptor signalling and cross-talk: Achieving rapidity and specificity. Cell Signal. 2002, 14, 397-405. [CrossRef]

8. Smith, J.S.; Lefkowitz, R.J.; Rajagopal, S. Biased signalling: From simple switches to allosteric microprocessors. Nat. Rev. Drug Discov. 2018, 17, 243-260. [CrossRef] [PubMed]

9. Seyedabadi, M.; Ghahremani, M.H.; Albert, P.R. Biased signaling of G protein coupled receptors (GPCRs): Molecular determinants of GPCR/transducer selectivity and therapeutic potential. Pharmacol. Ther. 2019, 200, 148-178. [CrossRef]

10. Lefkowitz, R.J. Historical review: A brief history and personal retrospective of seven-transmembrane receptors. Trends Pharmacol. Sci. 2004, 25, 413-422. [CrossRef]

11. Zhao, P.; Furness, S.G.B. The nature of efficacy at G protein-coupled receptors. Biochem. Pharmacol. 2019, 170, 113647. [CrossRef]

12. Zhang, R.; Xie, X. Tools for GPCR drug discovery. Acta. Pharm. Sin 2012, 33, 372-384. [CrossRef] [PubMed]

13. Miyano, K.; Sudo, Y.; Yokoyama, A.; Hisaoka-Nakashima, K.; Morioka, N.; Takebayashi, M.; Nakata, Y.; Higami, Y.; Uezono, Y. History of the G protein-coupled receptor (GPCR) assays from traditional to a state-of-the-art biosensor assay. J. Pharm. Sci. 2014, 126, 302-309. [CrossRef]

14. Yasi, E.A.; Kruyer, N.S.; Peralta-Yahya, P. Advances in G protein-coupled receptor high-throughput screening. Curr. Opin. Biotechnol. 2020, 64, 210-217. [CrossRef] [PubMed]

15. Schihada, H.; Vandenabeele, S.; Zabel, U.; Frank, M.; Lohse, M.J.; Maiellaro, I. A universal bioluminescence resonance energy transfer sensor design enables high-sensitivity screening of GPCR activation dynamics. Commun. Biol. 2018, 1, 105. [CrossRef]

16. Wan, Q.; Okashah, N.; Inoue, A.; Nehme, R.; Carpenter, B.; Tate, C.G.; Lambert, N.A. Mini G protein probes for active G protein-coupled receptors (GPCRs) in live cells. J. Biol. Chem. 2018, 293, 7466-7473. [CrossRef] [PubMed]

17. Misawa, N.; Kafi, A.K.M.; Hattori, M.; Miura, K.; Masuda, K.; Ozawa, T. Rapid and High-Sensitivity Cell-Based Assays of Protein-Protein Interactions Using Split Click Beetle Luciferase Complementation: An Approach to the Study of G-ProteinCoupled Receptors. Anal. Chem. 2010, 82, 2552-2560. [CrossRef] [PubMed]

18. Littmann, T.; Ozawa, T.; Hoffmann, C.; Buschauer, A.; Bernhardt, G. A split luciferase-based probe for quantitative proximal determination of Galphaq signalling in live cells. Sci. Rep. 2018, 8, 17179. [CrossRef]

19. Werner, K.; Neumann, D.; Buschauer, A.; Seifert, R. No evidence for histamine H4 receptor in human monocytes. J. Pharmacol. Exp. Ther. 2014, 351, 519-526. [CrossRef]

20. Lieb, S.; Littmann, T.; Plank, N.; Felixberger, J.; Tanaka, M.; Schafer, T.; Krief, S.; Elz, S.; Friedland, K.; Bernhardt, G.; et al. Label-free versus conventional cellular assays: Functional investigations on the human histamine H1 receptor. Pharmacol. Res. 2016, 114, 13-26. [CrossRef]

21. Bakker, R.A.; Casarosa, P.; Timmerman, H.; Smit, M.J.; Leurs, R. Constitutively active Gq/11-coupled receptors enable signaling by co-expressed G(i/o)-coupled receptors. J. Biol. Chem. 2004, 279, 5152-5161. [CrossRef] 
22. Bongers, G.; Sallmen, T.; Passani, M.B.; Mariottini, C.; Wendelin, D.; Lozada, A.; Marle, A.; Navis, M.; Blandina, P.; Bakker, R.A.; et al. The Akt/GSK-3beta axis as a new signaling pathway of the histamine H(3) receptor. J. Neurochem. 2007, 103, 248-258. [CrossRef] [PubMed]

23. Nordemann, U.; Wifling, D.; Schnell, D.; Bernhardt, G.; Stark, H.; Seifert, R.; Buschauer, A. Luciferase reporter gene assay on human, murine and rat histamine $\mathrm{H} 4$ receptor orthologs: Correlations and discrepancies between distal and proximal readouts. PLOS ONE 2013, 8, e73961. [CrossRef]

24. Kenakin, T. Biased Receptor Signaling in Drug Discovery. Pharm. Rev. 2019, 71, 267-315. [CrossRef]

25. Kenakin, T. A holistic view of GPCR signaling. Nat. Biotechnol. 2010, 28, 928-929. [CrossRef]

26. Scott, C.W.; Peters, M.F. Label-free whole-cell assays: Expanding the scope of GPCR screening. Drug Discov. Today 2010, 15, 704-716. [CrossRef]

27. Aristotelous, T.; Hopkins, A.L.; Navratilova, I. Chapter Twenty-Three-Surface Plasmon Resonance Analysis of SevenTransmembrane Receptors. In Methods in Enzymology; Shukla, A.K., Ed.; Academic Press: Cambridge, MA, USA, 2015; Volume 556, pp. 499-525.

28. Fang, Y. Label-free drug discovery. Front. Pharm. 2014, 5, 52. [CrossRef]

29. Fang, Y. Non-invasive Optical Biosensor for Probing Cell Signaling. Sensors 2007, 7, 2316-2329. [CrossRef] [PubMed]

30. Fang, Y.; Ferrie, A.; Fontaine, N.; Ki Yuen, P. Optical biosensors for monitoring dynamic mass redistribution in living cells mediated by epidermal growth factor receptor activation. Conf. Proc. IEEE Eng. Med. Biol. Soc. 2005, 2006, 666-669. [CrossRef] [PubMed]

31. Carter, R.L.; Grisanti, L.A.; Yu, J.E.; Repas, A.A.; Woodall, M.; Ibetti, J.; Koch, W.J.; Jacobson, M.A.; Tilley, D.G. Dynamic mass redistribution analysis of endogenous beta-adrenergic receptor signaling in neonatal rat cardiac fibroblasts. Pharmacol. Res. Perspect. 2014, 2, e00024. [CrossRef] [PubMed]

32. Jørgensen, C.V.; Zhou, H.; Seibel, M.J.; Bräuner-Osborne, H. Label-free dynamic mass redistribution analysis of endogenous adrenergic receptor signaling in primary preadipocytes and differentiated adipocytes. J. Pharmacol. Toxicol. Methods 2019, 97, 59-66. [CrossRef] [PubMed]

33. Ferrie, A.M.; Sun, H.; Zaytseva, N.; Fang, Y. Divergent label-free cell phenotypic pharmacology of ligands at the overexpressed beta(2)-adrenergic receptors. Sci. Rep. 2014, 4, 3828. [CrossRef] [PubMed]

34. Rocheville, M.; Jerman, J.C. 7TM pharmacology measured by label-free: A holistic approach to cell signalling. Curr. Opin. Pharm. 2009, 9, 643-649. [CrossRef] [PubMed]

35. Fang, Y.; Li, G.; Ferrie, A.M. Non-invasive optical biosensor for assaying endogenous G protein-coupled receptors in adherent cells. J. Pharmacol. Toxicol. Methods 2007, 55, 314-322. [CrossRef] [PubMed]

36. Ferrie, A.M.; Wang, C.; Deng, H.; Fang, Y. A label-free optical biosensor with microfluidics identifies an intracellular signalling wave mediated through the beta(2)-adrenergic receptor. Integr. Biol. 2013, 5, 1253-1261. [CrossRef]

37. Schröder, R.; Janssen, N.; Schmidt, J.; Kebig, A.; Merten, N.; Hennen, S.; Muller, A.; Blattermann, S.; Mohr-Andra, M.; Zahn, S.; et al. Deconvolution of complex $G$ protein-coupled receptor signaling in live cells using dynamic mass redistribution measurements. Nat. Biotechnol. 2010, 28, 943-949. [CrossRef]

38. Schröder, R.; Schmidt, J.; Blattermann, S.; Peters, L.; Janssen, N.; Grundmann, M.; Seemann, W.; Kaufel, D.; Merten, N.; Drewke, C.; et al. Applying label-free dynamic mass redistribution technology to frame signaling of $\mathrm{G}$ protein-coupled receptors noninvasively in living cells. Nat. Protoc. 2011, 6, 1748-1760. [CrossRef]

39. Tran, E.; Fang, Y. Label-free optical biosensor for probing integrative role of adenylyl cyclase in G protein-coupled receptor signaling. J. Recept. Signal. Transduct. Res. 2009, 29, 154-162. [CrossRef]

40. West, R.E., Jr.; Moss, J.; Vaughan, M.; Liu, T.; Liu, T.Y. Pertussis toxin-catalyzed ADP-ribosylation of transducin. Cysteine 347 is the ADP-ribose acceptor site. J. Biol. Chem 1985, 260, 14428-14430. [CrossRef]

41. Grundmann, M.; Merten, N.; Malfacini, D.; Inoue, A.; Preis, P.; Simon, K.; Ruttiger, N.; Ziegler, N.; Benkel, T.; Schmitt, N.K.; et al. Lack of beta-arrestin signaling in the absence of active $G$ proteins. Nat. Commun. 2018, 9, 341. [CrossRef]

42. Shi, Y.; Sheng, R.; Zhong, T.; Xu, Y.; Chen, X.; Yang, D.; Sun, Y.; Yang, F.; Hu, Y.; Zhou, N. Identification and characterization of ZEL-H16 as a novel agonist of the histamine H3 receptor. PLoS ONE 2012, 7, e42185. [CrossRef] [PubMed]

43. Gill, D.M.; Meren, R. ADP-ribosylation of membrane proteins catalyzed by cholera toxin: Basis of the activation of adenylate cyclase. Proc. Natl. Acad. Sci. USA 1978, 75, 3050-3054. [CrossRef] [PubMed]

44. Schrage, R.; Schmitz, A.L.; Gaffal, E.; Annala, S.; Kehraus, S.; Wenzel, D.; Bullesbach, K.M.; Bald, T.; Inoue, A.; Shinjo, Y.; et al. The experimental power of FR900359 to study Gq-regulated biological processes. Nat. Commun. 2015, 6, 10156. [CrossRef] [PubMed]

45. Lavenus, S.; Simard, E.; Besserer-Offroy, E.; Froehlich, U.; Leduc, R.; Grandbois, M. Label-free cell signaling pathway deconvolution of Angiotensin type 1 receptor reveals time-resolved G-protein activity and distinct AngII and AngIII $\backslash$ IV responses. Pharmacol. Res. 2018, 136, 108-120. [CrossRef]

46. Carr, R., 3rd; Koziol-White, C.; Zhang, J.; Lam, H.; An, S.S.; Tall, G.G.; Panettieri, R.A., Jr.; Benovic, J.L. Interdicting Gq Activation in Airway Disease by Receptor-Dependent and Receptor-Independent Mechanisms. Mol. Pharm. 2016, 89, 94-104. [CrossRef]

47. Ruzza, C.; Ferrari, F.; Guerrini, R.; Marzola, E.; Preti, D.; Reinscheid, R.K.; Calo, G. Pharmacological profile of the neuropeptide S receptor: Dynamic mass redistribution studies. Pharmacol. Res. Perspect. 2018, 6, e00445. [CrossRef] 
48. Antony, J.; Kellershohn, K.; Mohr-Andra, M.; Kebig, A.; Prilla, S.; Muth, M.; Heller, E.; Disingrini, T.; Dallanoce, C.; Bertoni, S.; et al. Dualsteric GPCR targeting: A novel route to binding and signaling pathway selectivity. FASEB J. Off. Publ. Fed. Am. Soc. Exp. Biol. 2009, 23, 442-450. [CrossRef] [PubMed]

49. Kebig, A.; Kostenis, E.; Mohr, K.; Mohr-Andra, M. An optical dynamic mass redistribution assay reveals biased signaling of dualsteric GPCR activators. J. Recept. Signal. Transduct. Res. 2009, 29, 140-145. [CrossRef] [PubMed]

50. Deng, H.; Wang, C.; Su, M.; Fang, Y. Probing biochemical mechanisms of action of muscarinic M3 receptor antagonists with label-free whole cell assays. Anal. Chem 2012, 84, 8232-8239. [CrossRef]

51. Watson, S.J.; Brown, A.J.; Holliday, N.D. Differential signaling by splice variants of the human free fatty acid receptor GPR120. Mol. Pharm. 2012, 81, 631-642. [CrossRef] [PubMed]

52. Qu, L.; Wang, J.; Hou, T.; Zhou, H.; Wang, Z.; Zhang, X.; Liang, X. Systematic characterization of AT1 receptor antagonists with label-free dynamic mass redistribution assays. J. Pharmacol. Toxicol. Methods 2020, 102, 106682. [CrossRef] [PubMed]

53. Hou, T.; Shi, L.; Wang, J.; Wei, L.; Qu, L.; Zhang, X.; Liang, X. Label-free cell phenotypic profiling and pathway deconvolution of neurotensin receptor-1. Pharmacol. Res. 2016, 108, 39-45. [CrossRef] [PubMed]

54. Milligan, G.; Inoue, A. Genome Editing Provides New Insights into Receptor-Controlled Signalling Pathways. Trends Pharmacol. Sci. 2018, 39, 481-493. [CrossRef] [PubMed]

55. Lukasheva, V.; Devost, D.; Le Gouill, C.; Namkung, Y.; Martin, R.D.; Longpré, J.-M.; Amraei, M.; Shinjo, Y.; Hogue, M.; Lagacé, M.; et al. Signal profiling of the $\beta 1 \mathrm{AR}$ reveals coupling to novel signalling pathways and distinct phenotypic responses mediated by $\beta 1 A R$ and $\beta 2 A R$. Sci. Rep. 2020, 10, 8779. [CrossRef]

56. Young, J.M.; Timmerman, H.; Thurmond, R.; Stark, H.; Shankley, N.P.; Seifert, R.; Schwartz, J.-C.; Schunack, W.; Panula, P.; Liu, S.; et al. Histamine receptors (version 2019.4) in the IUPHAR/BPS Guide to Pharmacology Database. IUPHAR/BPS Guide Pharmacol. CITE 2019, 2019. [CrossRef]

57. Panula, P.; Chazot, P.L.; Cowart, M.; Gutzmer, R.; Leurs, R.; Liu, W.L.; Stark, H.; Thurmond, R.L.; Haas, H.L. International Union of Basic and Clinical Pharmacology. XCVIII. Histamine Receptors. Pharm. Rev. 2015, 67, 601-655. [CrossRef]

58. Tiligada, E.; Ennis, M. Histamine pharmacology: From Sir Henry Dale to the 21st century. Br. J. Pharm. 2018, 177, 469-489. [CrossRef] [PubMed]

59. Okashah, N.; Wan, Q.; Ghosh, S.; Sandhu, M.; Inoue, A.; Vaidehi, N.; Lambert, N.A. Variable G protein determinants of GPCR coupling selectivity. Proc. Natl. Acad. Sci. USA 2019, 116, 12054-12059. [CrossRef]

60. Avet, C.; Mancini, A.; Breton, B.; Le Gouill, C.; Hauser, A.S.; Normand, C.; Kobayashi, H.; Gross, F.; Hogue, M.; Lukasheva, V.; et al. Selectivity Landscape of 100 Therapeutically Relevant GPCR Profiled by an Effector Translocation-Based BRET Platform. bioRxiv 2020. [CrossRef]

61. Esbenshade, T.A.; Kang, C.H.; Krueger, K.M.; Miller, T.R.; Witte, D.G.; Roch, J.M.; Masters, J.N.; Hancock, A.A. Differential activation of dual signaling responses by human $\mathrm{H} 1$ and $\mathrm{H} 2$ histamine receptors. J. Recept. Signal. Transduct. Res. 2003, $23,17-31$. [CrossRef]

62. Atwood, B.K.; Lopez, J.; Wager-Miller, J.; Mackie, K.; Straiker, A. Expression of G protein-coupled receptors and related proteins in HEK293, AtT20, BV2, and N18 cell lines as revealed by microarray analysis. BMC Genom. 2011, 12, 14. [CrossRef]

63. Stallaert, W.; van der Westhuizen, E.T.; Schonegge, A.M.; Plouffe, B.; Hogue, M.; Lukashova, V.; Inoue, A.; Ishida, S.; Aoki, J.; Le Gouill, C.; et al. Purinergic Receptor Transactivation by the beta2-Adrenergic Receptor Increases Intracellular Ca(2+) in Nonexcitable Cells. Mol. Pharm. 2017, 91, 533-544. [CrossRef] [PubMed]

64. Devost, D.; Sleno, R.; Petrin, D.; Zhang, A.; Shinjo, Y.; Okde, R.; Aoki, J.; Inoue, A.; Hebert, T.E. Conformational Profiling of the AT1 Angiotensin II Receptor Reflects Biased Agonism, G Protein Coupling, and Cellular Context. J. Biol. Chem. 2017, 292, 5443-5456. [CrossRef] [PubMed]

65. Bruysters, M.; Pertz, H.H.; Teunissen, A.; Bakker, R.A.; Gillard, M.; Chatelain, P.; Schunack, W.; Timmerman, H.; Leurs, R. Mutational analysis of the histamine H1-receptor binding pocket of histaprodifens. Eur. J. Pharm. 2004, 487, 55-63. [CrossRef] [PubMed]

66. Pertz, H.H.; Gornemann, T.; Schurad, B.; Seifert, R.; Strasser, A. Striking differences of action of lisuride stereoisomers at histamine $\mathrm{H}_{1}$ receptors. Naunyn-Schmiedeberg's Arch. Pharmacol. 2006, 374, 215-222. [CrossRef]

67. Moguilevsky, N.; Varsalona, F.; Noyer, M.; Gillard, M.; Guillaume, J.P.; Garcia, L.; Szpirer, C.; Szpirer, J.; Bollen, A. Stable expression of human H1-histamine-receptor cDNA in Chinese hamster ovary cells. Pharmacological characterisation of the protein, tissue distribution of messenger RNA and chromosomal localisation of the gene. Eur. J. Biochem 1994, 224, 489-495. [CrossRef]

68. Sibley, D.R.; Mahan, L.C.; Creese, I. Dopamine receptor binding on intact cells. Absence of a high-affinity agonist-receptor binding state. Mol. Pharm. 1983, 23, 295-302.

69. Baumeister, P.; Erdmann, D.; Biselli, S.; Kagermeier, N.; Elz, S.; Bernhardt, G.; Buschauer, A. [(3)H]UR-DE257: Development of a tritium-labeled squaramide-type selective histamine $\mathrm{H} 2$ receptor antagonist. ChemMedChem 2015, 10, 83-93. [CrossRef] [PubMed]

70. Igel, P.; Schnell, D.; Bernhardt, G.; Seifert, R.; Buschauer, A. Tritium-labeled N(1)-[3-(1H-imidazol-4-yl)propyl]-N(2)propionylguanidine ([(3)H]UR-PI294), a high-affinity histamine $\mathrm{H}(3)$ and $\mathrm{H}(4)$ receptor radioligand. ChemMedChem 2009, 4, 225-231. [CrossRef] [PubMed] 
71. Bosma, R.; Witt, G.; Vaas, L.A.I.; Josimovic, I.; Gribbon, P.; Vischer, H.F.; Gul, S.; Leurs, R. The Target Residence Time of Antihistamines Determines Their Antagonism of the G Protein-Coupled Histamine H1 Receptor. Front. Pharm. 2017, 8, 667. [CrossRef]

72. Tran, E.; Ye, F. Duplexed label-free G protein-coupled receptor assays for high-throughput screening. J. Biomol Screen 2008, 13, 975-985. [CrossRef] [PubMed]

73. Lieb, S.; Michaelis, S.; Plank, N.; Bernhardt, G.; Buschauer, A.; Wegener, J. Label-free analysis of GPCR-stimulation: The critical impact of cell adhesion. Pharmacol. Res. 2016, 108, 65-74. [CrossRef]

74. Tran, E.; Sun, H.; Fang, Y. Dynamic mass redistribution assays decode surface influence on signaling of endogenous purinergic P2Y receptors. Assay Drug Dev. Technol. 2012, 10, 37-45. [CrossRef] [PubMed]

75. Malfacini, D.; Simon, K.; Trapella, C.; Guerrini, R.; Zaveri, N.T.; Kostenis, E.; Calo, G. NOP receptor pharmacological profile-A dynamic mass redistribution study. PLoS ONE 2018, 13, e0203021. [CrossRef]

76. Wifling, D.; Loffel, K.; Nordemann, U.; Strasser, A.; Bernhardt, G.; Dove, S.; Seifert, R.; Buschauer, A. Molecular determinants for the high constitutive activity of the human histamine H4 receptor: Functional studies on orthologues and mutants. Br. J. Pharm. 2015, 172, 785-798. [CrossRef] [PubMed]

77. Bakker, R.A.; Wieland, K.; Timmerman, H.; Leurs, R. Constitutive activity of the histamine H1 receptor reveals inverse agonism of histamine H1 receptor antagonists. Eur. J. Pharmacol. 2000, 387, R5-R7. [CrossRef]

78. Wieland, K.; Bongers, G.; Yamamoto, Y.; Hashimoto, T.; Yamatodani, A.; Menge, W.M.; Timmerman, H.; Lovenberg, T.W.; Leurs, R. Constitutive activity of histamine $\mathrm{h}(3)$ receptors stably expressed in SK-N-MC cells: Display of agonism and inverse agonism by H(3) antagonists. J. Pharmacol. Exp. Ther. 2001, 299, 908-914.

79. Schihada, H.; Ma, X.; Zabel, U.; Vischer, H.F.; Schulte, G.; Leurs, R.; Pockes, S.; Lohse, M.J. Development of a Conformational Histamine H3 Receptor Biosensor for the Synchronous Screening of Agonists and Inverse Agonists. ACS Sens. 2020, 5, 1734-1742. [CrossRef]

80. Horing, C.; Seibel, U.; Tropmann, K.; Gratz, L.; Monnich, D.; Pitzl, S.; Bernhardt, G.; Pockes, S.; Strasser, A. A Dynamic, SplitLuciferase-Based Mini-G Protein Sensor to Functionally Characterize Ligands at All Four Histamine Receptor Subtypes. Int. J. Mol. Sci. 2020, 21, 8440. [CrossRef]

81. Preuss, H.; Ghorai, P.; Kraus, A.; Dove, S.; Buschauer, A.; Seifert, R. Constitutive activity and ligand selectivity of human, guinea pig, rat, and canine histamine H2 receptors. J. Pharmacol. Exp. Ther. 2007, 321, 983-995. [CrossRef]

82. Seifert, R.; Wenzel-Seifert, K. Constitutive activity of G-protein-coupled receptors: Cause of disease and common property of wild-type receptors. Naunyn-Schmiedeberg's Arch. Pharmacol. 2002, 366, 381-416. [CrossRef]

83. Kenakin, T. Efficacy as a Vector: The Relative Prevalence and Paucity of Inverse Agonism. Mol. Pharmacol. 2004, 65, 2-11. [CrossRef] [PubMed]

84. Scheff, J.D.; Almon, R.R.; Dubois, D.C.; Jusko, W.J.; Androulakis, I.P. Assessment of pharmacologic area under the curve when baselines are variable. Pharm Res. 2011, 28, 1081-1089. [CrossRef] [PubMed]

85. Elmer, P. Development Guide for. Cell-Based Label.-Free Assays, 1st ed.; Perkin Elmer: Waltham, MA, USA, 2013.

86. Deng, H.; Sun, H.; Fang, Y. Label-free cell phenotypic assessment of the biased agonism and efficacy of agonists at the endogenous muscarinic M3 receptors. J. Pharmacol. Toxicol. Methods 2013, 68, 323-333. [CrossRef] [PubMed]

87. Fang, Y. The development of label-free cellular assays for drug discovery. Expert Opin. Drug Discov. 2011, 6, 1285-1298. [CrossRef] [PubMed]

88. Chio, C.L.; Lajiness, M.E.; Huff, R.M. Activation of heterologously expressed D3 dopamine receptors: Comparison with D2 dopamine receptors. Mol. Pharm. 1994, 45, 51-60.

89. Bartole, E.; Grätz, L.; Littmann, T.; Wifling, D.; Seibel, U.; Buschauer, A.; Bernhardt, G. UR-DEBa242: A Py-5-Labeled Fluorescent Multipurpose Probe for Investigations on the Histamine H3 and H4 Receptors. J. Med. Chem. 2020, 63, 5297-5311. [CrossRef] [PubMed]

90. Khoury, E.; Clément, S.; Laporte, S.A. Allosteric and Biased G Protein-Coupled Receptor Signaling Regulation: Potentials for New Therapeutics. Front. Endocrinol. 2014, 5, 38. [CrossRef]

91. Inoue, A.; Raimondi, F.; Kadji, F.M.N.; Singh, G.; Kishi, T.; Uwamizu, A.; Ono, Y.; Shinjo, Y.; Ishida, S.; Arang, N.; et al. Illuminating G-Protein-Coupling Selectivity of GPCRs. Cell 2019, 177, 1933-1947.e25. [CrossRef]

92. Lehmann, D.M.; Seneviratne, A.M.; Smrcka, A.V. Small molecule disruption of G protein beta gamma subunit signaling inhibits neutrophil chemotaxis and inflammation. Mol. Pharm. 2008, 73, 410-418. [CrossRef] [PubMed]

93. Kim, Y.S.; Kim, Y.B.; Kim, W.B.; Lee, S.W.; Oh, S.B.; Han, H.C.; Lee, C.J.; Colwell, C.S.; Kim, Y.I. Histamine 1 receptor-GbetagammacAMP/PKA-CFTR pathway mediates the histamine-induced resetting of the suprachiasmatic circadian clock. Mol. Brain 2016, 9, 49. [CrossRef] [PubMed]

94. Bonacci, T.M.; Mathews, J.L.; Yuan, C.; Lehmann, D.M.; Malik, S.; Wu, D.; Font, J.L.; Bidlack, J.M.; Smrcka, A.V. Differential targeting of Gbetagamma-subunit signaling with small molecules. Science 2006, 312, 443-446. [CrossRef] [PubMed]

95. Houston, C.; Wenzel-Seifert, K.; Burckstummer, T.; Seifert, R. The human histamine H2-receptor couples more efficiently to Sf9 insect cell Gs-proteins than to insect cell Gq-proteins: Limitations of Sf9 cells for the analysis of receptor/Gq-protein coupling. J. Neurochem. 2002, 80, 678-696. [CrossRef]

96. Oda, T.; Morikawa, N.; Saito, Y.; Masuho, Y.; Matsumoto, S. Molecular cloning and characterization of a novel type of histamine receptor preferentially expressed in leukocytes. J. Biol. Chem. 2000, 275, 36781-36786. [CrossRef] 
97. Plank, N. Dimeric Histamine H2 Receptor Agonists as Molecular Tools and Genetically Engineered HEK293T Cells as an Assay Platform to Unravel Signaling Pathways of hH1R and hH2R. Ph.D. Thesis, University of Regensburg, Regensburg, Germany, 2015. [CrossRef]

98. Bakker, R.A.; Nicholas, M.W.; Smith, T.T.; Burstein, E.S.; Hacksell, U.; Timmerman, H.; Leurs, R.; Brann, M.R.; Weiner, D.M. In vitro pharmacology of clinically used central nervous system-active drugs as inverse $\mathrm{H}-1$ receptor agonists. J. Pharmacol. Exp. Ther. 2007, 322, 172-179. [CrossRef] [PubMed]

99. Casale, T.B.; Rodbard, D.; Kaliner, M. Characterization of histamine H-1 receptors on human peripheral lung. Biochem. Pharmacol. 1985, 34, 3285-3292. [CrossRef]

100. Fitzsimons, C.P.; Monczor, F.; Fernandez, N.; Shayo, C.; Davio, C. Mepyramine, a histamine H1 receptor inverse agonist, binds preferentially to a $G$ protein-coupled form of the receptor and sequesters G protein. J. Biol. Chem. 2004, 279, 34431-34439. [CrossRef]

101. Höring, C.; Conrad, M.; Söldner, C.A.; Wang, J.; Sticht, H.; Strasser, A.; Miao, Y. Specific Engineered G Protein Coupling to Histamine Receptors Revealed from Cellular Assay Experiments and Accelerated Molecular Dynamics Simulations. Int. J. Mol. Sci. 2021, 22, 10047.

102. Bosma, R.; Moritani, R.; Leurs, R.; Vischer, H.F. BRET-based beta-arrestin2 recruitment to the histamine H1 receptor for investigating antihistamine binding kinetics. Pharmacol. Res. 2016, 111, 679-687. [CrossRef]

103. Fernandez, N.; Monczor, F.; Baldi, A.; Davio, C.; Shayo, C. Histamine H2 receptor trafficking: Role of arrestin, dynamin, and clathrin in histamine H2 receptor internalization. Mol. Pharm. 2008, 74, 1109-1118. [CrossRef]

104. Nijmeijer, S.; Vischer, H.F.; Rosethorne, E.M.; Charlton, S.J.; Leurs, R. Analysis of multiple histamine H(4) receptor compound classes uncovers Galphai protein- and beta-arrestin2-biased ligands. Mol. Pharm. 2012, 82, 1174-1182. [CrossRef] [PubMed]

105. Micallef, S.; Stark, H.; Sasse, A. Polymorphisms and genetic linkage of histamine receptors. Life Sci. 2013, 93, 487-494. [CrossRef] [PubMed]

106. Leary, P.J.; Kronmal, R.A.; Bluemke, D.A.; Buttrick, P.M.; Jones, K.L.; Kao, D.P.; Kawut, S.M.; Krieger, E.V.; Lima, J.A.; Minobe, W.; et al. Histamine H2 Receptor Polymorphisms, Myocardial Transcripts, and Heart Failure (from the Multi-Ethnic Study of Atherosclerosis and Beta-Blocker Effect on Remodeling and Gene Expression Trial). Am. J. Cardiol. 2018, 121, 256-261. [CrossRef] [PubMed]

107. Gu, J.; Mao, X.H.; Yang, X.Z.; Ao, H.F.; Zhang, Z.; Li, Y. Histamine H4 receptor gene polymorphisms: A potential predictor of oral H1 antihistamine efficacy for allergic rhinitis. Int. Forum. Allergy Rhinol. 2017, 7, 268-275. [CrossRef] [PubMed]

108. Chu, J.T. Histamine $\mathrm{H} 1$ receptor gene polymorphism acts as a biological indicator of the prediction of therapeutic efficacy in patients with allergic rhinitis in the Chinese Han population. J. Cell Biochem. 2019, 120, 164-170. [CrossRef]

109. Wei, Z.; Wang, L.; Zhang, M.; Xuan, J.; Wang, Y.; Liu, B.; Shao, L.; Li, J.; Zeng, Z.; Li, T.; et al. A pharmacogenetic study of risperidone on histamine $\mathrm{H} 3$ receptor gene (HRH3) in Chinese Han schizophrenia patients. J. Psychopharmacol. 2012, 26, 813-818. [CrossRef]

110. Li, J.; Chen, W.; Peng, C.; Zhu, W.; Liu, Z.; Zhang, W.; Su, J.; Li, J.; Chen, X. Human H1 receptor (HRH1) gene polymorphism is associated with the severity of side effects after desloratadine treatment in Chinese patients with chronic spontaneous uticaria. Pharm. J. 2020, 20, 87-93. [CrossRef] [PubMed]

111. Rosier, N.; Gratz, L.; Schihada, H.; Moller, J.; Isbilir, A.; Humphrys, L.J.; Nagl, M.; Seibel, U.; Lohse, M.J.; Pockes, S. A Versatile Sub-Nanomolar Fluorescent Ligand Enables NanoBRET Binding Studies and Single-Molecule Microscopy at the Histamine H3 Receptor. J. Med. Chem. 2021, 64, 11695-11708. [CrossRef] [PubMed]

112. Kagermeier, N.; Werner, K.; Keller, M.; Baumeister, P.; Bernhardt, G.; Seifert, R.; Buschauer, A. Dimeric carbamoylguanidine-type histamine H2 receptor ligands: A new class of potent and selective agonists. Bioorg. Med. Chem. 2015, 23, 3957-3969. [CrossRef]

113. Yung-Chi, C.; Prusoff, W.H. Relationship between the inhibition constant (KI) and the concentration of inhibitor which causes 50 per cent inhibition (I50) of an enzymatic reaction. Biochem. Pharmacol. 1973, 22, 3099-3108. [CrossRef] 